\title{
AS PROVAS NÃO REPETÍVEIS NO PROCESSO PENAL BRASILEIRO
}

\author{
Dissertação de Mestrado \\ Orientador: Professor Doutor José Raul Gavião de Almeida \\ FACULDADE DE DIREITO DA UNIVERSIDADE DE SÃO PAULO
}

São Paulo, março de 2012 
CAMILLA BRENTEL

\section{AS PROVAS NÃO REPETÍVEIS NO PROCESSO PENAL BRASILEIRO}

Dissertação de Mestrado apresentada à Faculdade de Direito da Universidade de São Paulo como um dos requisitos para a obtenção do título de Mestre em Direito.

Orientador: Professor José Raul Gavião de Almeida

São Paulo, março de 2012 
Banca Examinadora: 
Tudo vale a pena se a alma não é pequena.

(Fernando Pessoa).

Dedico este singelo trabalho àqueles que, durante sua elaboração, não me deixaram esquecer da inexorável verdade contida nestas palavras:

Minha mãe, Sandra, cuja dedicação e amor incondicionais permitiramme transformar o sonho do mestrado em realidade. Você é meu maior exemplo de vida e foi minha inspiração para superar os momentos de dificuldade.

Meu namorado, Fernando, que mesmo a dez mil quilômetros de distância, esteve ao meu lado em todos os instantes. Seu amor e empenho estão impressos nas páginas deste trabalho. 


\section{AGRADECIMENTOS:}

Muitas pessoas doaram seu amor, conhecimento e tempo para que este estudo pudesse ser realizado. Agradeço aos familiares, amigos e professores que contribuíram ao meu aprimoramento, acadêmico e humano, ensinando-me a importância do estudo e da dedicação como mecanismos de aperfeiçoamento e evolução.

Agradeço, em especial, ao Professor José Raul Gavião de Almeida, que mais que um orientador, tem importância especial em minha vida. O senhor foi meu primeiro professor na cadeira de processo penal no curso de graduação da Faculdade de Direito do Largo São Francisco, e seus ensinamentos em sala de aula exerceram papel fundamental na minha escolha profissional. Agradeço-o pelas oportunidades profissionais e acadêmicas e pela confiança que sempre depositou em mim, desde a época de meu estágio no Tribunal de Justiça do Estado de São Paulo, em 2006, até hoje, enquanto assistente jurídica da mesma instituição. Tenho pelo senhor um carinho filial e sou muito grata pelos constantes exemplos de trabalho, dedicação, doação e amor ao próximo.

Agradeço ao Professor Antonio Scarance Fernandes por seus aconselhamentos quanto à escolha do tema desta dissertação. O estudo das provas não repetíveis é tema instigante e muito contribuiu ao desenvolvimento de minha maturidade acadêmica. O Professor Scarance mostrou-me, durante as aulas e o convívio no curso de pós-graduação da Faculdade de Direito do Largo São Francisco, que a utilização do processo penal como mecanismo de transformação da realidade só é possível quando, ao seu estudo, nos dedicamos com amor e empenho.

Agradeço à Professora Marta Saad, pelas importantes contribuições ao desenvolvimento deste trabalho na banca de minha qualificação; ao Professor Edson Tetsuso, por ter-me concedido a honra de tê-lo em minha banca examinadora da dissertação; aos Professores Maurício Zanoide de Moraes, Marcos Antonio Coelho Zilli, Gustavo Henrique Righy Ivahy Badaró e Antonio Magalhães Gomes Filho, por todo o aprendizado no curso de pósgraduação. 
Agradeço aos queridos colegas do curso de pós-graduação, em especial Mariângela, Márcio, Salles, Pedro Ivo, Fernanda e Camila, que fizeram dele uma experiência ainda mais enriquecedora e gratificante.

Agradeço aos meus amigos de trabalho, Luzia, Mônica, Maurício, Luís Guilherme e Luiz Geraldo, cujo apoio, incentivo e torcida foram fundamentais à conclusão deste estudo.

Tenho um especial agradecimento a fazer a alguns de meus melhores amigos. Carla, Ana Francisca, Eduardo, Alessandra, Alex, Bruna e Cristina, obrigada pela amizade de anos e pela torcida mais que verdadeira. Obrigada por serem tão especiais e presentes em minha vida. Conceição, sem sua ajuda, torcida e motivação eu não teria conseguido concluir este trabalho. Obrigada pelo carinho e preocupação diários.

Seria impossível colocar em poucas linhas os motivos pelos quais eu agradeço à minha família, fonte de inspiração e valores. Agradeço, especialmente, à minha mãe, Sandra, a meu pai, Rodnei, às minhas irmãs, Lorinne e Isabella, a meus avós, Wilson, Nair e Dalva, a meus padrinhos, Rachel e Oscar, e à minha tia Wilma por tudo o que representam em minha vida e que sempre fizeram por mim. A Fernando, eu agradeço pelo companheirismo, pelo valioso auxílio na elaboração deste trabalho e por todo seu amor. Obrigada a todos! 


\section{RESUMO}

O Código de Processo Penal brasileiro foi alterado em 2008 em decorrência da promulgação de algumas Leis Ordinárias. Uma delas $\left(n^{\circ} 11.690\right)$ prescreveu a modificação do artigo 155, a fim de regulamentar a aceitação de provas não repetíveis (e outras produzidas durante as investigações) para o convencimento do julgador. No entanto, como o legislador não atribuiu significado às provas não repetíveis, tampouco teceu esclarecimentos a respeito do modo como tais provas seriam compatibilizadas com o princípio constitucional do contraditório, há muitas incertezas sobre a disposição, que tem sido objeto de discussão pela comunidade jurídica. O silêncio do legislador impediu o desenvolvimento de uma regulação eficiente sobre o assunto. Com o objetivo de contribuir para as atuais discussões, propomos uma análise comparativa da doutrina sobre provas não repetíveis utilizada na Itália, país que serviu de inspiração à criação da norma brasileira. Por meio deste estudo, pretendemos: (i) clarificar o conceito de provas não repetíveis; (ii) analisar a interação do conceito de provas não repetíveis com outras provas produzidas durante as investigações; (iii) alcançar a compreensão do tratamento normativo e doutrinário das provas não repetíveis nos processos penais brasileiro e italiano; e (iv) refletir, à luz da das regras estabelecidas na Constituição Brasileira, se a regulamentação italiana sobre as provas não repetíveis teria aplicação no processo penal brasileiro. Depois de realizadas tais aferições, refletiremos sobre a necessidade de reformulação do artigo 155 que, se confirmada, nos levará à porposição de um novo texto normativo. 


\begin{abstract}
The Brazilian Criminal Procedure Code was altered in 2008 as a result of the adoption of some Ordinary Laws. One of them ( $\mathrm{n}^{\circ}$. 11.690) prescribed amendments in article 155, which from then on stipulates the acceptance of non-repeatable evidence (as well as other types of evidence produced during investigations), as means of conviction. Nevertheless, as the legislator neither provided a definition of non-repeatable evidence nor instructed how this evidence should be treated in regards to the adversarial system of justice guaranteed by the Brazilian Constitution, there is a lot of uncertainty on the juridical community concerning this provision. The silence of the legislator deterred the development of an efficient regulation on the matter. Aiming to contribute to the current discussions, this work is focused on the comparative analysis of the doctrine of nonrepeatable evidence as applied in Italy, cradle of this idea. This study intends to: (i) clarify the concept of non-repeatable evidence; (ii) scrutinize the interaction of the concept of non-repeatable evidence with the further evidences produced during investigation; (iii) comprehend, in light of the Italian doctrine and the rules set forth in the Brazilian Constitution, the scope of application of the non-repeatable evidence; and (iv) analyze, bearing in mind the rules contained in the Brazilian Constitution, whether the system of non-repeatable evidence prescribed in Italy could also be applied in the Brazilian Criminal Procedure. After all these considerations are made, the crux of this work will be on whether article 155 should be rephrased and, if affirmative, how the new article should be worded.
\end{abstract}




\section{SUMÁRIO}

INTRODUÇÃO.

CAPÍTULO I. ASPECTOS GERAIS DA TEORIA DAS PROVAS APLICÁVEIS AO ESTUDO DA

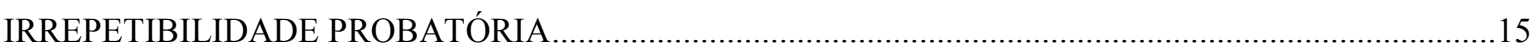

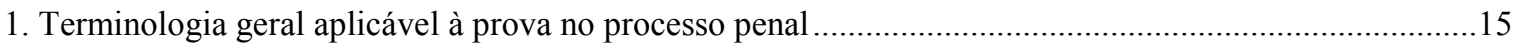

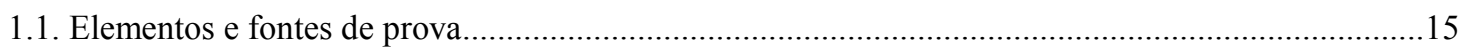

1.2. Meios de produção de prova e meios de investigação.......................................................................16

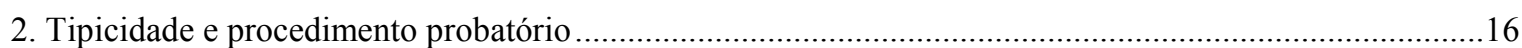

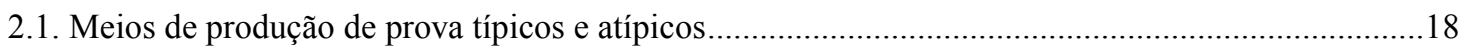

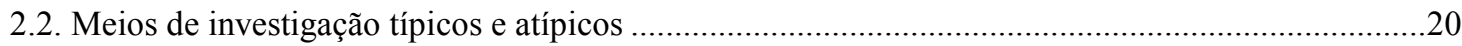

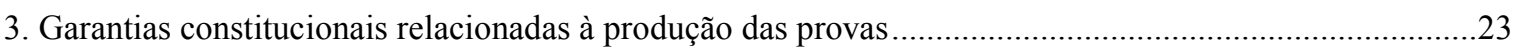

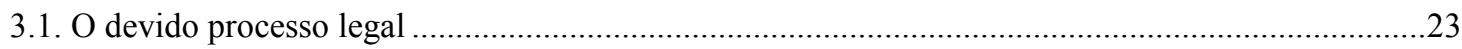

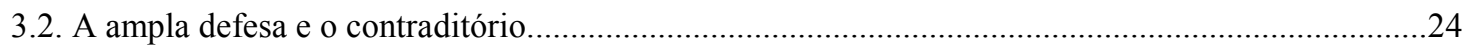

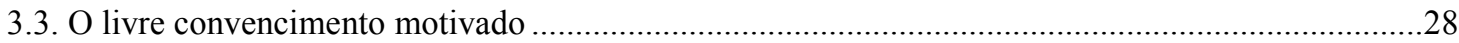

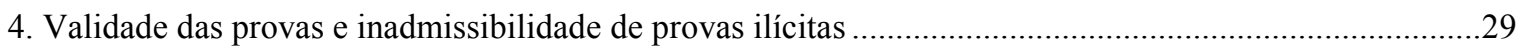

CAPÍTULO II. OS FENÔMENOS PROBATÓRIOS DA ETAPA INVESTIGATIVA: TERMINOLOGIA, TRATAMENTO E PROPOSTA DE SISTEMATIZAÇÃO ..........................................................................33

1. Considerações gerais sobre o inquérito policial e sua relação com as provas ..............................................33

2. Terminologia aplicável aos fenômenos probatórios da fase investigativa ...................................................38

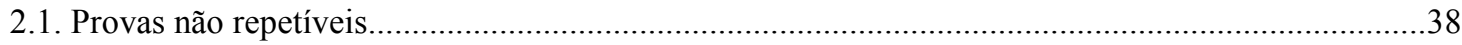

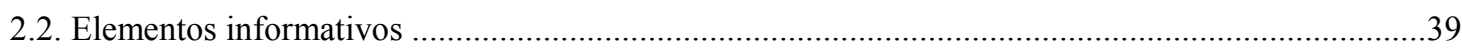

2.3. Provas cautelares lato sensu: provas antecipadas e provas cautelares stricto sensu.........................41

3. Análise da disciplina normativa autorizadora das provas não repetíveis....................................................45

3.1. O artigo 155 do Código de Processo Penal e seu trâmite legal no Brasil...........................................45

3.2. Comentários sobre a norma

4. Uma proposta de sistematização terminológica sobre a irrepetibilidade das provas .....................................53

4.1. A prova repetível e sua classificação (prova repetível perfeita e imperfeita).....................................54

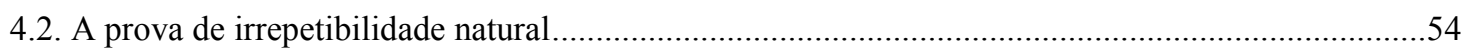


4.3. A prova de irrepetibilidade superveniente.

CAPÍTULO III. PROVAS REPETÍVEIS E NÃO REPETÍVEIS: UMA ANÁLISE À LUZ DAS REGRAS

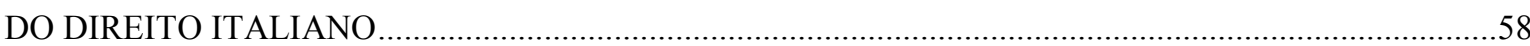

1. As provas de fases anteriores do processo: aceitabilidade e disciplina normativa ...............................58

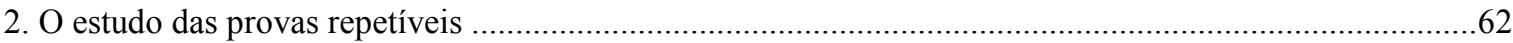

2.1. Aspectos relevantes e problemática relacionada à prova repetível perfeita ..................................62

2.2. Aspectos relevantes e problemática relacionada à prova repetível imperfeita ..............................66

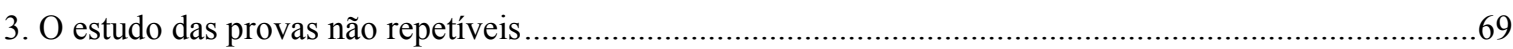

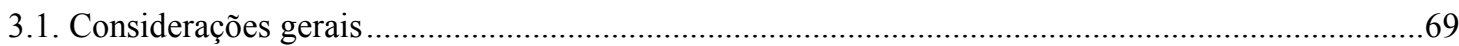

3.2. Aspectos relevantes e problemática relacionada à prova naturalmente irrepetível .........................72

3.2. Aspectos relevantes e problemática relacionada à prova de irrepetibilidade superveniente .............86

4. Reflexões finais sobre a aplicabilidade das regras italianas ao direito brasileiro e proposta de alteração

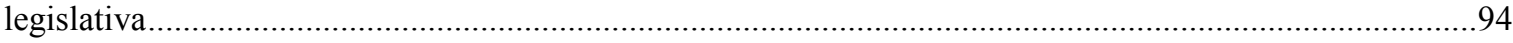

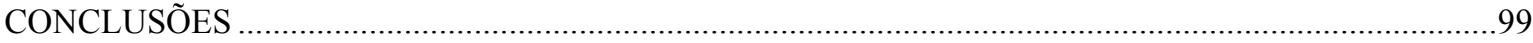

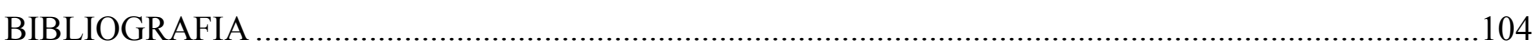




\section{INTRODUÇÃO}

Ao tratar da aprovação da Lei n ${ }^{\circ} 11.690$, a qual culminou na edição do atual artigo 155 do Código de Processo Penal, um dos seus idealizadores asseverou que o legislador brasileiro inspirou-se "claramente em disposição do Código de Processo Penal italiano, de 1988, que autoriza a leitura, na fase de debates, de declarações prestadas anteriormente perante a Polícia Judiciária ou o MP, na investigação, ou diante do juiz, no curso da audiência preliminar, quando por fatos ou circunstâncias imprevisíveis, tornou-se impossível a sua repetição (art. 512 do CPP italiano)"1. A inspiração adveio de norma do processo penal italiano que prevê a excepcional possibilidade de aceitação de prova formada à revelia do princípio do contraditório, em casos de impossibilidade de natureza objetiva ${ }^{2}$.

A comparação entre sistemas jurídicos para o aprimoramento do direito interno tem especial importância nos países de história recente como o Brasil, que, descoberto no século XVI, viu o nascimento de suas duas primeiras faculdades de direito somente no século XIX. Desde muito tempo nota-se a utilização do direito comparado como mecanismo de aperfeiçoamento do direito nacional. É inegável, por exemplo, a influência do direito francês sobre os direitos administrativo e trabalhista, do direito alemão sobre o direito tributário, e do direito italiano sobre os direitos civil, penal e processual brasileiros.

O problema em utilizar-se de normas alienígenas como fonte de direito resulta da inadequação, por vezes sentida, entre o sistema jurídico do país que as fornece (para o qual contribuem os valores morais, culturais e a conjuntura sócio-política da sociedade, em determinado momento da história) e aquele que as adota.

É correta a afirmação de RENÉ DAVID sobre a necessidade de adaptação do instituto jurídico que será transplantado de um ordenamento para o outro, já no processo legislativo que lhe dá vida: "num período de vinte, de dez anos, ou mesmo inferior, a reforma que foi realizada num país e que aí provou o seu valor, é introduzida noutros países, com uma ou

\footnotetext{
${ }^{1}$ GOMES FILHO, Antonio Magalhães. Provas: Lei 11.690, de 9.6.2008. In: MOURA, Maria Thereza Rocha de Assis. (Org.). As reformas no processo penal: as novas leis de 2008 e os projetos de reforma. São Paulo: Revista dos Tribunais, 2009, p. 254-255.

${ }^{2}$ Artigo 111 da Constituição da República Italiana.
} 
outra modificação, levando em conta circunstâncias especiais que visam aperfeiçoá-la ou integrá-la mais perfeitamente no direito desse novo país"3.

Mas nem sempre a necessária adequação é realizada no nascedouro da lei que incorpora o instituto do direito alienígena ao ordenamento jurídico interno. Esta é, muitas vezes, tarefa realizada posteriormente, pelos cientistas do direito. Com efeito, "não só o legislador pode utilizar o direito comparado para aperfeiçoar o direito. Idêntica possibilidade está aberta à doutrina e à jurisprudência. A lei pode ter um caráter nacional; o direito jamais se identifica efetivamente com a lei. A ciência do direito tem, pela sua própria natureza de ciência, um caráter transnacional" ${ }^{4}$.

Assim, cumpre à jurisprudência e à doutrina perquirirem a essência do instituto no país de origem para, confrontando-o com as regras e princípios de direito nacional, dar-lhe os contornos que permitirão sua adequação aos anseios da sociedade e aos princípios constitucionalmente erigidos. É o que buscaremos fazer neste estudo sobre provas não repetíveis no processo penal brasileiro.

Antes mesmo do advento da Lei n 11.690 de 2008, o Código de Processo Penal brasileiro já previa a garantia do livre convencimento motivado ${ }^{5}$. Esta garantia fora assegurada na lei processual penal de forma genérica e era comumente interpretada no sentido de que o julgador poderia valer-se das provas submetidas ao contraditório e, subsidiariamente, dos elementos informativos produzidos no inquérito (mesmo que não submetidos à contradita das partes) para a formação de sua convicção. A jurisprudência predominava neste sentido.

O artigo 157, com a redação original do Código, foi revogado e substituído em agosto de 2008 pelo atual artigo 155, que buscou uma melhor delimitação da garantia do livre convencimento motivado. O conteúdo do novo texto do artigo de lei, todavia, foi insatisfatório.

\footnotetext{
${ }^{3}$ DAVID, René. 1906. Os grandes sistemas do direito contemporâneo (Les grands systèmes du droit contemporains) - Tradução Hermínio A. Carvalho, $4^{\mathrm{a}}$ ed., São Paulo: Martins Fontes, 2002, p. 07.

${ }^{4}$ DAVID, René. 1906. Os grandes sistemas...op. cit., p. 08.

${ }^{5}$ Artigo 157, com redação dada pelo Decreto-Lei 3.689/1941: “o juiz formará sua convicção pela livre apreciação da prova".
} 
A reforma era ansiada há tempos e havia expectativa de que, por meio dela, houvesse a sedimentação do entendimento de que a convicção do julgador deveria pautar-se exclusivamente nas provas submetidas ao contraditório. $\mathrm{O}$ que houve, entretanto, foi a positivação legal do entendimento anterior, que previa a possibilidade de utilização do material probatório colhido no inquérito, muitas vezes sem a participação da defesa, para dar base à condenação criminal.

Mais do que isso, criaram-se outros problemas, até hoje não solucionados. Ao incluir no texto legal as expressões cautelares, não repetíveis e antecipadas o legislador o fez de forma inconsistente: não houve atribuição de significado, tampouco regulamentação legal da irrepetibilidade probatória; houve confuso esclarecimento com relação à forma de atuação do contraditório - real ou diferido - sobre as espécies de prova nomeadas (não repetíveis, cautelares e antecipadas), dando margem à equivocada interpretação de que elas estariam libertas da obrigatoriedade de submeter-se à contradita das partes; nenhum esclarecimento foi dado a respeito do modo como elementos informativos do inquérito seriam compatibilizados com a garantia do contraditório.

A não atribuição dos significados e omissão quanto à forma de atuação dos termos empregados pelo legislador torna árdua a tarefa de se analisar a legalidade do próprio dispositivo legal. Mais que mera norma processual, a garantia do contraditório disposta no artigo 155 do Código de Processo Penal é princípio constitucional. E como norma constitucional, não pode ser derrogada ou mitigada por lei infraconstitucional. Em outros termos, se a regra é o respeito ao contraditório, deve-se certificar de que o material probatório utilizado para formar a convicção do julgador (entre o que se incluem as provas não repetíveis) respeite o princípio. Do contrário, estaríamos diante de norma processual penal, completa ou parcialmente, inconstitucional.

Propomos, em razão do exposto, uma singela análise de direito comparado na tentativa de (i) clarificar o conceito de provas não repetíveis; (ii) analisar a interação do conceito de provas não repetíveis com outras provas produzidas durante as investigações; (iii) alcançar a compreensão do tratamento normativo e doutrinário das provas não repetíveis nos processos penais brasileiro e italiano; e (iv) refletir, à luz da das regras estabelecidas na 
Constituição Brasileira, se a regulamentação italiana sobre as provas não repetíveis teria aplicação no processo penal brasileiro. Depois de realizadas tais aferições, refletiremos sobre a necessidade de reformulação do artigo 155 que, se confirmada, nos levará à proposição de um novo texto normativo.

É importante ressaltar que não temos por escopo realizar um estudo exaustivo do tema, mas um estudo colaborativo ao fomento de sua discussão. O trabalho será dividido em três capítulos.

No primeiro capítulo, no qual apresentaremos a terminologia geral associada às provas no processo penal e os princípios e regras constitucionais que, direta ou indiretamente, mantêm relação com o tema de nosso estudo, discutir-se-à a teoria das provas.

O segundo capítulo servirá às considerações sobre a produção de provas durante as investigações; ao alcance da compreensão dos fenômenos probatórios da fase investigativa (elementos informativos, provas não repetíveis, cautelares e antecipadas); à análise do artigo 155 do Código de Processo Penal; e à proposição de uma sistematização terminológica sobre a irrepetibilidade probatória.

No terceiro capítulo realizaremos uma análise de direito comparado. Por meio desta buscaremos apontar o tratamento do tema na Itália e examinar, à luz das disposições deste ordenamento jurídico, os aspectos relevantes e os problemas relacionados ao fenômeno da irrepetibilidade probatória. Também neste capítulo aferiremos a possibilidade de utilização da regulamentação do direito italiano (relacionada à aceitação de provas produzidas nas investigações) no processo penal brasileiro e seu alcance. Por fim, focaremos na atual redação do artigo 155 e possíveis alterações cabíveis para melhor clarificar o tratamento das provas não repetíveis no ordenamento pátrio. 


\section{CAPÍTULO I. ASPECTOS GERAIS DA TEORIA DAS PROVAS APLICÁVEIS AO ESTUDO DA IRREPETIBILIDADE PROBATÓRIA}

\section{Terminologia geral aplicável à prova no processo penal}

\subsection{Elementos e fontes de prova}

O vocábulo prova (do latim probus: probo ou correto) ${ }^{6}$ é polissêmico e seu significado depende do contexto em que é empregado. Interessa-nos neste trabalho compreender a terminologia associada à complexa atividade probatória do processo penal. Para tanto, servimo-nos das lições de GOMES FILHO, para quem o termo prova assume quatro diferentes significados: fonte, elemento, meio de investigação (ou meio de pesquisa) e meio de prova (ou meio de produção de prova) ${ }^{7}$.

Entende-se por fonte de prova o objeto ou a pessoa que possam trazer informações úteis (ou, na linguagem processual, elementos de prova) ao processo. Em outros termos, o que for "idôneo a fornecer resultados relevantes para a decisão do juiz" prova para o processo. As fontes de prova serão reais (objetos) ou pessoais (testemunhas, vítimas, peritos e acusados em geral).

Pode-se dizer que elementos de prova são "os dados objetivos que confirmam ou negam uma asserção a respeito de um fato que interessa à decisão da causa",; "aquilo que se extrai da fonte da prova quando ainda não foi valorada pelo juiz" "10. Tratam-se das informações apresentadas pela testemunha, vítima ou acusado, do conteúdo extraído de determinado documento ou da opinião emitida pelo perito criminal (fontes de prova) capazes de integrarem o conjunto probatório submetido ao convencimento do julgador

\footnotetext{
${ }^{6}$ Dicionário Houaiss da língua portuguesa. Rio de Janeiro: Objetiva, 2003.

${ }^{7}$ GOMES FILHO, Antonio Magalhães. Notas sobre a terminologia da prova (reflexos no processo penal brasileiro). In: YARSHELL, Flávio Luis; MORAES, Maurício Zanoide (Org.). Estudos em homenagem à professora Ada Pellegrini Grinover. 1a ed., São Paulo: DPJ, 2005, p. 306-310.

${ }^{8}$ TONINI, Paolo. A prova no processo penal italiano (tradução de Alexandra Martins e Daniele Mróz). São Paulo: Revista dos tribunais, 2002, p. 52.

${ }_{9}^{9}$ GOMES FILHO, Antonio Magalhães. Notas sobre a terminologia ... op. cit., p. 307.

${ }^{10}$ TONINI, Paolo. A prova ..., op. cit., p. 52.
} 


\subsection{Meios de produção de prova e meios de investigação}

Meios de produção de prova (ou meios de prova) são "os instrumentos ou atividades por intermédio dos quais os dados probatórios (elementos de prova) são introduzidos e fixados no processo" $" 11$. Por eles possibilita-se a transformação de uma informação importante (contida na fonte) em elemento de prova, vale dizer, em conhecimento partilhado e debatido entre os interessados no processo, sendo, portanto, capaz de formar o convencimento do julgador. Trata-se de atividade desenvolvida sob a presidência do magistrado e com participação ativa das partes, através do exercício do contraditório.

Os meios de investigação (também denominados meios de pesquisa ou meios de obtenção de prova) são mecanismos utilizados com o escopo de descobrir potenciais fontes de prova que servirão ao processo. GOMES FILHO, com base em Comoglio, esclarece que "os meios de investigação não são, por si, fonte de conhecimento, mas servem para adquirir coisas materiais, traços ou declarações dotadas de força probatória, e que também podem ter como destinatários a polícia judiciária ou o Ministério Público" ${ }^{\text {12. }}$.

\section{Tipicidade e procedimento probatório}

O estudo da atipicidade probatória ${ }^{13}$ tem importância especial no processo penal. Por meio desta a doutrina analisa a possibilidade de aceitação de meios de prova e meios de investigação cuja regulamentação legal seja insatisfatória ou inexistente.

O direito ao procedimento é uma das facetas da garantia do devido processo legal. Por ele se assegura às partes que a produção da prova dar-se-á dentro de determinados limites legais, seguindo-se uma sequência de atos coordenados. FERNANDES, através das lições de Liebman, aborda o conceito teleológico do procedimento, segundo o qual os atos que o

\footnotetext{
${ }^{11}$ GOMES FILHO, Antonio Magalhães. Notas sobre a terminologia ... op . cit., p. 308.

12 GOMES FILHO, Antonio Magalhães. Notas sobre a terminologia ... op. cit., p. 309.

${ }^{13}$ Para um maior aprofundamento do tema da tipicidade probatória, ver: LARONGA, Antonio. Le prove atipiche nel processo penale, Padova: Cedam, 2002.
} 
compõem somam-se, visando a um resultado final que terá "eficácia externa e não meramente processual" 14 .

Neste contexto, a produção da prova deve seguir o procedimento probatório ao qual a lei faz referência, sob pena de violação ao devido processo legal e consequente nulidade do ato praticado. Nas hipóteses em que a lei é omissa, deve-se recorrer à analogia, vale dizer, deve-se utilizar de procedimentos previstos em lei para a produção de outros meios de $\operatorname{prova}^{15}$.

Em linhas gerais, no que tange à tipificação legal, os meios de produção de prova e os meios de investigação podem: (i) ser previstos em lei e regulados com procedimento próprio;(ii) ser previstos, não regulados, mas com remissão a procedimento a ser seguido; (iii) ser previstos, não regulados e sem remissão a qualquer procedimento existente; (iv) ser apenas referidos nominalmente, sem regulação ou remissão a procedimento; e (v) não ser sequer referidos em lei ${ }^{16}$.

Dois entendimentos erigiram-se, originalmente na Itália, quanto às situações mencionadas: um denominado restritivo e outro ampliativo (ou não restritivo). Pela teoria restritiva entende-se típico o meio de investigação ou de produção de prova a que a lei fizer menção, pouco importando se possui ou não procedimento e regulamentação legal ${ }^{17}$.Pela corrente ampliativa - a qual nos filiamos - será típico o meio de prova ou de investigação que estiver previsto em lei, com procedimento probatório próprio, ou analogamente apontado, para sua utilização ${ }^{18}$.

\footnotetext{
${ }^{14}$ In: FERNANDES, Antonio Scarance. Processo Penal Constitucional, $6^{\text {a }}$ ed. revisada, atualizada e ampliada - São Paulo: Revista dos tribunais, 2010, p. 106.

${ }^{15}$ GOMES FILHO, Antonio Magalhães; BADARÓ, Gustavo Henrique Righi Ivahy. Prova e sucedâneos de prova no processo penal brasileiro. In: Revista Brasileira de Ciências Criminais, $\mathrm{n}^{\circ}$ 65, São Paulo: Editora Revista dos Tribunais, março-abril de 2007.

${ }^{16}$ Cf. FERNANDES, Antonio Scarance. Prova e sucedâneos da prova no processo penal, Revista Brasileira de Ciências Criminais, maio-junho de 2007, Revista dos Tribunais, p.199.

${ }^{17}$ Cf. LARONGA, Antonio. Le prove atipiche... op. cit., p. 17.

${ }^{18}$ Cf. FERNANDES, Antonio Scarance. Prova e sucedâneos...op. cit., p. 199.
} 


\subsection{Meios de produção de prova típicos e atípicos}

O Código de Processo Penal brasileiro disciplina alguns meios de produção de prova típicos. São eles a prova testemunhal (artigos 201 a 225), algumas provas periciais ${ }^{19}$ (artigos 158 a 184), a prova documental (artigos 231 a 238) e o reconhecimento de pessoas e coisas (artigos 226 a 228). Note-se que, embora também se encontrem tipificados na lei, não são tratados como efetivos meios de prova o interrogatório (artigos 185 a 196), entendido pela moderna doutrina como meio de defesa ${ }^{20}$, os indícios (artigo 239) e a confissão (artigos 197 a 200), estes dependentes da observância de regras especiais para que sejam utilizados ${ }^{21}$.

De igual modo, são disciplinados no Código de Processo Penal italiano a prova testemunhal (artigos 194 a 207), a acareação (artigos 211 e 212), o reconhecimento (artigos 213 a 217), a reconstituição dos fatos (artigos 218 e 219), as perícias ${ }^{22}$ (artigos 220 a 233)

\footnotetext{
19 As perícias descritas no Código de Processo Penal possuem regulamentação genérica - quanto aos quesitos, ao exame e número de peritos, à produção do laudo pericial e à participação das partes e dos assistentes técnicos. Outras, de importância no contexto probatório, sequer possuem regulamentação, como é o caso do exame de DNA, do teste de alcoolemia por "bafômetro" e de outras perícias tecnológicas. A doutrina ressalta a impossibilidade prática de regulamentação dos procedimentos relacionados à prova pericial, que decorre, em grande medida, da velocidade de modificação das modernas técnicas empregadas em sua realização. A questão da tipicidade da prova pericial é tema atual, em discussão doutrinária.

${ }^{20}$ Posicionam-se desta forma, por exemplo, Ada Pellegrini Grinover, Antonio Magalhães Gomes Filho, Fernando da Costa Tourinho Filho e Antonio Scarance Fernandes. Por todos: FERNANDES, Antonio Scarance. Prova e sucedâneos...op. cit., p. 203.

${ }^{21}$ Com efeito, a confissão, quando proferida, é divisível e retratável. E para que possa servir à condenação deve ser confrontada com as demais provas - e com elas ser concordante. O indício, por sua vez, é método interpretativo-indutivo por meio do qual se infere das circunstâncias já provadas outras que dela decorram. Segundo Gomes Filho, o indício é um dado objetivo que, embora não desprovido de eficácia probatória, não autoriza uma inferência segura sobre os fatos a serem demonstrados. In: GOMES FILHO, Antonio Magalhães. Notas sobre a terminologia ... op. cit., p. 311 . O artigo 192 do Código de Processo Penal italiano enfatiza que naquele sistema a existência de um fato não pode ser aferida por indícios, exceto se eles forem graves, precisos e concordantes. Segundo TONINI, precisos são os indícios que não são suscetíveis a diversas interpretações, graves são aqueles que resistem ao confronto, tendo elevado poder de persuasão, e consonantes são os que convergem para uma única conclusão (In: TONINI, Paolo. A prova ..., op. cit., p.5859).

${ }^{22}$ Esclarece a doutrina sobre a dificuldade de conceituação da prova pericial como meio de prova: Muito se discute sobre a natureza jurídica da perícia. Embora inserido entre os meios de produção de prova pelo diploma processual, sustenta-se que não o é, porque dela não resulta a formação de dados probatórios. Cuida-se, em verdade, de mera valoração sobre dados probatórios já existentes. ARANTES FILHO, Marcio Geraldo Britto. A disciplina da prova no Código de Processo Penal italiano. In: Provas no processo penal estudo comparado. FERNANDES, Antonio Scarance; ALMEIDA, José Raul Gavião; MORAES, Maurício Zanoide (coordenadores). São Paulo: Saraiva, 2011, p. 255.
} 
e os documentos ${ }^{23}$ (234 a 243). Acrescenta-se, aqui, o exame de partes privadas ${ }^{24}$ (artigos 208 a 210), que não é tipificado como meio de prova no processo penal brasileiro.

De maneira geral, diz-se que a prova desrespeitadora do procedimento estabelecido na lei é nula. Assim, tanto "a prova típica, produzida sem a observância de seu procedimento probatório" 25 como "a prova típica utilizada ou para fins diversos dos que lhe são próprios, ou para fins característicos de outras provas típicas" ${ }^{26}$ serão eivadas de nulidade.

É importante ressaltar que além dos meios de prova típicos (repita-se, aqueles previstos em lei, com procedimento probatório próprio ou análogo) outros são hábeis a propiciar a introdução de elementos de prova no processo. Tratam-se dos meios de prova atípicos, cuja utilização é possível em razão do princípio da liberdade probatória.

\footnotetext{
23 "Documento é o meio de prova pré-constituído, no qual se materializa a representação de um fato estranho e, normalmente, anterior ao processo. Outra coisa bem distinta é a documentação dos atos processuais, isto é, o seu registro por meio de símbolos. Enquanto o documento representa algo que está fora do procedimento, sendo extraprocessual, a documentação representa um ato do próprio procedimento, sendo, portanto, endoprocessual. Assim, pois, tal declaração da possível testemunha é a documentação de um ato do procedimento investigatório, realizado pelo Ministério Público, e não um documento propriamente dito". Cf. BADARÓ, Gustavo Henrique Ivahy Badaró. Provas atípicas e provas anômalas: inadmissibilidade da substituição da prova testemunhal pela juntada de declarações escritas de quem poderia ser testemunha. In: YARSHELL, Flávio Luis; MORAES, Maurício Zanoide (Org.). Estudos em homenagem ... op. cit., p. 350-351.

${ }^{24}$ Consideram-se partes privadas as pessoas que não devam ser ouvidas na condição de testemunhas, vale dizer, que não sejam obrigadas a dizer a verdade e a responder aos questionamentos que lhe são formulados. Assim, por exemplo, a parte civil e o réu.

${ }^{25}$ Cf. BADARÓ, Gustavo Henrique Ivahy (In: Provas atípicas e provas anômalas: inadmissibilidade da substituição da prova testemunhal pela juntada de declarações escritas de quem poderia ser testemunha. In: YARSHELL, Flávio Luis; MORAES, Maurício Zanoide (Org.). Estudos em homenagem ... op. cit., p. 344). No mesmo sentido: LARONGA, Antonio. Le prove atipiche... op. cit., p. 13. Trata-se da prova irritual: meio de prova regulamentado pela lei e com procedimento preestabelecido, mas não obedecido ao ser utilizado. Difere-se, portanto, da prova atípica, que se refere à prova não prevista em lei e cujo procedimento deve ser o referente a algum meio de prova típico.

${ }^{26}$ Cf. BADARÓ, Gustavo Henrique Ivahy (In: Provas atípicas e provas anômalas: inadmissibilidade da substituição da prova testemunhal pela juntada de declarações escritas de quem poderia ser testemunha. In: YARSHELL, Flávio Luis; MORAES, Maurício Zanoide (Org.). Estudos em homenagem ... op. cit., p. 344345). Trata-se da prova anômala prova típica que, mesmo dotada de procedimento próprio, utiliza o procedimento de outro meio de prova típico para ser produzida. Sua problematização refere-se especialmente à impropriedade na utilização da prova testemunhal como se documental fosse - no caso em que pessoas que poderiam depor como testemunhas em audiência (de forma oral, sob o crivo do contraditório, com imediação) o fazem informalmente, perante uma das partes (advogado de defesa ou Ministério Público), que documenta o ato e o leva para o processo, com o escopo de transformá-lo em meio de prova documental (prova pré-constituída).
} 
O princípio da liberdade probatória não é expresso no Código de Processo Penal, mas aplicam-se, por analogia, o artigo 332 do Código de Processo Civil ("todos os meios legais, bem como os moralmente legítimos, ainda que não especificados neste Código, são hábeis para provar a verdade dos fatos em que se funda a ação ou a defesa") e o artigo 295 do Código de Processo Penal militar ("é admissivel, nos termos deste Código, qualquer espécie de prova, desde que não atente contra a moral, a saúde ou a segurança individual ou coletiva, ou contra a hierarquia ou a disciplina militares").

O Código de Processo Penal brasileiro nomeia, mas não indica, o procedimento para a realização das acareações (artigos 229 e 230) e das reconstituições (artigo $6^{\circ}$, inciso VI). Alguns meios de prova atípicos não são sequer nominados, como é o caso do reconhecimento por voz e do exame de DNA.

$\mathrm{Na}$ Itália, onde também vige princípio da liberdade probatória, a doutrina esclarece que a prova atípica (disciplinada 189 do Código de Processo Penal italiano) deve ser idônea e moralmente aceita. Além disso, sua produção encontra restrições, não podendo ser utilizada se houver prova típica hábil a gerar o mesmo resultado, restrições impostas pela lei civil ou impedimento previsto nas regras de produção da prova ${ }^{27}$.

\subsection{Meios de investigação típicos e atípicos}

Entendemos que a investigação policial dos fatos criminosos pode ocorrer por duas vias. A primeira delas, por meio de procedimentos investigatórios simples, que não reflitam grandes discussões sobre violações a direitos (por exemplo, a identificação do suspeito e a oitiva informal de testemunhas ou vítimas na cena do crime). Tais práticas, corriqueiras, não necessitam de acompanhamento e autorização judicial para que sejam realizadas; elas independem de previsão legal para que sejam válidas, embora devam ser moralmente legítimas quando não relacionadas pela lei. Em outras palavras, podem ser típicas ou atípicas.

\footnotetext{
${ }^{27}$ Nesse sentido: DEZEM. Guilherme Madeira. Da prova penal: tipo processual, provas típicas e atípicas atualizado de acordo com as Leis 11.689/08, 11.690/08 e 11.719/08. Campinas: Millenium, 2008, p. 283284. Ver, ainda: LARONGA, Antonio. Le prove atipiche... op. cit.
} 
A segunda forma relaciona-se à utilização de meios de investigação mais complexos, que tenham potencial aptidão para lesionar direitos e garantias constitucionalmente asseguradas aos investigados (como buscas domiciliares e interceptações telefônicas).

Amiúde, a doutrina subdivide esses meios de investigação em quatro grupos: (i) exames, vistorias e revistas;(ii) buscas, apreensões e sequestros; (iii) interceptações, escutas e quebras de sigilo; e (iv) atividades que tenham por objetivo a investigação de crimes graves, como a criminalidade organizada (a exemplo da entrega vigiada, das ações encobertas e da infiltração policial) ${ }^{28}$.

Referidas técnicas de investigação são mais invasivas e somente podem ser empregadas pela polícia em situações excepcionais, quando autorizadas pela autoridade judicial. Nestes casos, o procedimento será presidido pelo magistrado autorizador da medida, que fiscalizará a legalidade do ato e coibirá possíveis abusos dos agentes executores. E, no caso de constatar irregularidades, declarará a ilicitude e consequente inadmissibilidade da prova no processo.

Note-se que embora os meios de investigação desta segunda categoria possam restringir garantias individuais (em razão de seu sopesar com outros princípios constitucionais, cuja relevância para o caso concreto é-lhes superior), a restrição deve limitar-se àquela permitida pelo ordenamento. Não deve haver tolerância a indevidas restrições a direitos.

Destarte, para serem válidos, devem ser utilizados com respeito ao procedimento previsto para sua efetivação. O contrário (ausência de um procedimento legalmente estabelecido, ou analogamente apontado) implicaria na impossibilidade de fiscalização judicial sobre a legalidade da produção da prova. Apoiamo-nos, assim, na corrente doutrinária que prima pela necessidade de tipificação dos meios de investigação invasivos ${ }^{29}$.

\footnotetext{
${ }^{28}$ Cf. FERNANDES, Antonio Scarance. Tipicidade e sucedâneos de prova. In: Provas no processo penalestudo... op. cit. p. 24.

${ }^{29} \mathrm{Na}$ mesma linha: "se não se discute mais a impositividade da parêmia "nulla poena nullun crimen sine lege', o mesmo se dá com sua correspondente projeção processual ('nulla coactio sine lege') e pela qual devem ser 'tipificadas' tanto as condições de aplicação, com o conteúdo das intervenções processuais no âmbito dos direitos fundamentais dos cidadãos. Nessa transposição de áreas jurídico-criminais, os atributos inerentes a toda lei penal material serão também insitos às normas processuais infraconstitucionais, de
} 
No que respeita às diferenças entre os meios de produção de prova e os meios de investigação, pode-se dizer que os primeiros referem-se à atividade essencialmente endoprocessual, judicializada, praticada na presença das partes (que atuam em contraditório real), para o qual há previsão de nulidade quando do desrespeito ao modelo normativamente estipulado, e que os segundos, diversamente, aludem à atividade extraprocessual, realizada pela polícia judiciária, por vezes dependente de autorização judicial (na hipótese de serem invasivos) e efetivado sem a participação das partes (em razão do elemento surpresa ${ }^{30}$ ), mas submetido ao contraditório (na modalidade diferida), sem o que não poderia servir ao convencimento do julgador. Note-se que os meios de investigação violadores do procedimento determinado em lei são inadmissíveis no processo $^{31}$.

O Código de Processo Penal brasileiro não distingue meios de produção de prova de meios de investigação, tratando-os conjuntamente no Título VII (intitulado Da Prova) do Código de Processo Penal. Mas sabe-se que pertencem ao plexo dos meios de investigação no Brasil as buscas e apreensões, mencionadas no Código de Processo Penal, e outros procedimentos descritos na legislação esparsa, a exemplo das interceptações telefônicas (Lei $n^{\circ}$ 9296/96) e ambientais, de sinais eletromagnéticos, óticos e acústicos (Lei $n^{\circ}$ 10217/01), do agente policial infiltrado (Lei ${ }^{\circ}$ 9034/95 e Lei $n^{\circ} 11343 / 06$ ) e da entrega vigiada (Lei $\left.n^{0} 11343 / 06\right)$.

Esta orientação é diversa da adotada pela Itália. O Livro III (Prove) do Código de Processo Penal italiano é subdividido em três partes, uma sobre disposições gerais, outra sobre os

finalidade restritiva, pois elas deverão ser prévias, escritas e estritas" (In: MORAES. Maurício Zanoide de. Presunção de Inocência no processo penal brasileiro: análise da estrutura normativa para a elaboração legislativa e para a decisão judicial. Rio de Janeiro: Lumen Juris, 2010, p. 315). Nada obstante adotemos a referida posição, deve-se mencionar existir respeitável corrente doutrinária que entende, em nome do princípio da liberdade probatória, ser possível a utilização de meios de investigação atípicos, contanto que se possibilite a fiscalização dos atos praticados mediante contraditório diferido. Nesse sentido, ANTONIO LARONGA (In: Le prove atipiche... op. cit., p. 29-32), Delfino Siracusano (Le prove: i mezzi di ricerca della prova. In: SIRACUSANO, Delfino; GALATI, Antonini; TRANCHINA, Giovanni; ZAPPALÀ, Enzo. Diritto Processuale Penale. Milano: Giuffrè, vol. 1, 2006, p. 400), entre outros.

${ }^{30}$ Segundo GOMES FILHO, a principal diferença entre os meios de investigação e os de produção de prova "reside na surpresa que quase sempre acompanha os procedimentos de investigação, sem a qual seria inviável a obtenção das fontes de prova". In: GOMES FILHO, Antonio Magalhães. Notas sobre a terminologia ... op. cit., p. 309.

${ }^{31}$ Cf. GOMES FILHO, Antonio Magalhães. Notas sobre a terminologia ... op. cit., p. 310. 
meios de prova e uma terceira, que disciplina separadamente, os meios de investigação: Titolo I: Disposizioni generali (artigos 187-193); Titolo II: Mezzi di prova (artigos 194243); e Titolo III: Mezzi di ricerca della prova(artigos 244-271). São meios de investigação previstos no Código de Processo Penal italiano as inspeções ${ }^{32}$, as buscas, os sequestros (apreensões) e as interceptações de conversas ou comunicações informáticas e telemáticas, disciplinadas entre os artigos 244 e 271.

\section{Garantias constitucionais relacionadas à produção das provas}

\subsection{O devido processo legal}

O processo criminal é o método empregado pelo Estado para a solução de conflitos decorrentes do desrespeito às leis penais. São alguns de seus objetivos a pacificação social, a proteção aos direitos individuais dos envolvidos e a coibição de comportamentos contrários à ordem e ao bem comum, por meio da aplicação de sanções.

Tanto no Brasil como na Itália predomina o processo criminal do tipo acusatório ${ }^{33}$, conduzido por juiz imparcial, em um procedimento determinado por lei, a fim de que sejam assegurados os direitos fundamentais aos cidadãos. Em outras palavras, neles impera o princípio do devido processo legal.

\footnotetext{
32 Embora não seja tratada na legislação processual penal brasileira, o é no Código de Processo Civil. Fernandes explica predominar no Brasil o entendimento de que a inspeção judicial é, para o processo penal, prova típica, em razão de haver possibilidade de uso do procedimento estabelecido na lei processual civil, por analogia. FERNANDES, Antonio Scarance. Tipicidade e sucedâneos de prova. In: Provas no processo penal - estudo... op. cit. p. 24.

${ }^{33}$ No qual o juiz que decide a causa não é responsável pela investigação dos fatos, e o poder de instruir provas é, em regra, conferido às partes. De maneira geral, os sistemas inquisitivo, misto e acusatório traduzem a sobreposição (total ou parcial) ou a completa separação da titularidade das atividades de acusar, defender e julgar. No sistema inquisitivo - que predominou na Europa Continental até o período da revolução francesa e, em especial, na Itália até o Código de Processo Penal de 1930 (Código Rocco) - as funções de investigar, produzir a prova, e julgar recaíam sobre o juiz. No sistema penal misto (ou sistema formal acusatório) - predominante ainda hoje em França e Espanha - o processo é dividido em duas etapas judiciais, a primeira (instrução criminal) de caráter inquisitivo, cuja investigação dos fatos e a produção da prova são controladas por juiz de direito, de forma sigilosa e parcial, e a segunda (juízo oral), de aspecto acusatório, cujas funções de acusar, defender e julgar são delimitadas, o juiz (diferente daquele que atuou na etapa de instrução criminal) é imparcial, o contraditório é pleno e a oralidade, imediação e publicidade são garantidas.
} 
A garantia do devido processo legal está disciplinada no inciso LIV do artigo $5^{\circ}$ da Constituição Federal, segundo o qual ninguém poderá ser privado de sua liberdade ou bens, senão por meio de processo que se desenvolva na forma prevista em lei. Foi também contemplada no caput do artigo 111 da Constituição da República Italiana, que prevê que a jurisdição se dará mediante o giusto processo regulamentado na lei.

Pode-se dizer que o devido processo legal é o princípio sintetizador de diversos outros, também constitucionalmente assegurados: a presunção da inocência, o duplo grau de jurisdição, o direito de ser citado e de ser intimado de todas as decisões que comportem recurso, a ampla defesa, o contraditório, a publicidade, o juiz natural, a imparcialidade do julgador, o direito às vias recursais, a proibição da reformatio in pejus, o respeito à coisa julgada, a proibição das provas colhidas ilicitamente, a motivação das sentenças judiciais, a celeridade processual, a retroatividade da lei penal benigna, a dignidade humana, a integridade física, a liberdade e a igualdade ${ }^{34}$.

Mais especificamente na esfera do direito processual penal, o devido processo legal traduzse naquilo que FERNANDES denomina "devido processo penal" 35 , que sintetiza o direto à prova e ao procedimento, e os princípios da proporcionalidade, da igualdade e do contraditório.

\subsection{A ampla defesa e o contraditório}

Em linhas gerais, a ampla defesa é o princípio disposto no inciso LV da Constituição brasileira que garante aos acusados nos processos judiciais ou administrativos todos os meios de defesa e os recursos a estes inerentes. Ela condensa os direitos à autodefesa, à defesa técnica, a manifestar-se sobre os atos e termos do processo, a recorrer de decisões injustas, por meio da garantia do duplo grau de jurisdição, e à acompanhar a produção das

\footnotetext{
34 Cf. TOURINHO FILHO, Fernando da Costa. Manual de Processo Penal. $8^{\text {a }}$ ed. revisada e atualizada. São Paulo: Saraiva, 2006, p. 26.

${ }^{35}$ In: FERNANDES, Antonio Scarance. Processo Penal ...op.cit., $3^{\mathrm{a}}$ ed., p. 42-44.
} 
provas, podendo requerê-las e contraditá-las ${ }^{36}$. Trata-se, assim, de condição sem a qual não é possível dizer-se legítima e lícita a decisão judicial.

O artigo 24 da Constituição italiana garante a ampla defesa como um direito inviolável em todas as etapas do procedimento, sendo mesmo possível ao réu promover investigação particular, em igualdade com a acusação, conforme dispõe o artigo 38 do Código de Processo Penal italiano. Também o artigo 111 da Constituição italiana prevê a garantia da ampla defesa, ao dispor que "nos processos criminais a lei garantirá que a pessoa acusada de um delito: seja informada, o quanto antes e reservadamente, sobre a natureza e os motivos da acusação contra si existente; que disponha de tempo hábil e das condições necessárias para preparar sua defesa; que tenha a faculdade, ante o juiz, de interrogar ou de fazer interrogar aqueles que contra ela deporem; obter a convocação e o interrogatório de pessoas para deporem em sua defesa, nas mesmas condições que a acusação, bem como de utilizar qualquer outro meio de prova a seu favor; e ter a assistência de um intérprete caso não compreenda ou fale a língua utilizada no processo".

O contraditório, por sua vez, consubstancia-se na existência de relação dialética entre as partes, sem a qual as provas não seriam hábeis a embasar a decisão judicial. Trata-se da "ciência bilateral dos atos e termos processuais e a possibilidade de contrariá-los"37. Está assegurado no artigo $5^{\circ}$, inciso LV da Constituição brasileira, que prevê "aos litigantes, em processo judicial ou administrativo, e aos acusados em geral são assegurados o contraditório e a ampla defesa, com os meios e recursos a ela inerentes". E também no artigo 111 da Constituição italiana ("o processo se desenvolverá mediante o contraditório entre as partes").

A doutrina suscita dúvida quanto às relações estabelecidas entre a garantia da ampla defesa e o contraditório. Há entendimento de que a primeira deriva do segundo (em razão de a citação do acusado ser o primeiro ato contraditório do processo, a permitir sua defesa) e,

\footnotetext{
${ }^{36}$ Nesse sentido, GRECO FILHO, Vicente. Tutela constitucional das liberdades. São Paulo: Saraiva: 1989, p. 110 .

37 ALMEIDA, Canuto Mendes de. Princípios fundamentais do Processo Penal, São Paulo: Revista dos Tribunais, 1973, p. 82.
} 
diversamente, de que o segundo deriva da primeira (haja vista que o contraditório seria apenas uma das facetas de manifestação da defesa no processo). Nada obstante a discussão, FERNANDES ensina:

"Não se vislumbra, contudo, entre a defesa e o contraditório, relação de primazia ou de derivação. Defesa e contraditório estão intimamente relacionados e ambos são manifestações da garantia genérica do devido processo legal. O processo, pela sua própria natureza, exige partes em posições opostas, uma delas necessariamente em posição de defesa, e para que, no seu desenvolvimento, seja garantida a correta aplicação da justiça, impõe-se que cada um tenha o direito de se contrapor aos atos e termos da parte contrária. São, assim, a defesa e o contraditório, como também a ação, manifestações simultâneas, ligadas entre si pelo processo, sem que um instituto derive do outro",38.

Prova disso é que na fase inquisitiva da persecução penal brasileira garante-se a utilização de mecanismos de defesa, mas não do contraditório.

$\mathrm{Na}$ esfera civil o contraditório é disponível, traduzindo a possibilidade - e não a obrigatoriedade - de reação defensiva. Nesta área do direito a ausência de contraditório sobre os termos e atos disponíveis geram, em regra, a presunção relativa da veracidade das alegações do autor da demanda ${ }^{39}$.

Distintamente, no processo penal o contraditório deve ser pleno e efetivo, não podendo nele haver omissões da defesa. Prova disso é que o desrespeito aos diretos à informação e participação no processo constituem nulidade absoluta, conforme disciplina o artigo 564, inciso III, alíneas $c$ (ausência de nomeação de defensor ao réu presente, que o não tiver, ou ao ausente) , e (ausência da citação do réu para ver-se processar, o seu interrogatório, quando presente, e os prazos concedidos à acusação e à defesa), $g$ (ausência de intimação do réu para a sessão de julgamento, pelo Tribunal do Júri, quando a lei não permitir o julgamento à revelia), $h$ (ausência de intimação das testemunhas arroladas no libelo e na

\footnotetext{
${ }^{38}$ FERNANDES, Antonio Scarance. Processo Penal ...op.cit., 6 a ed., p. 253.

${ }^{39}$ LIEBMAN, Enrico Tullio. Manuale di Diritto Processuale Civile, $2^{\mathrm{a}}$ ed., vol. 1, Milano: Giuffrè, 1968, p. 228 e ss.
} 
contrariedade, nos termos estabelecidos pela lei), $l$ (ausência da acusação e da defesa, na sessão de julgamento) e $o$ (ausência da intimação, nas condições estabelecidas pela lei, para ciência de sentenças e despachos de que caiba recurso) do Código de Processo Penal.

O contraditório nasce da veemente necessidade de manifestação das partes sobre as provas que serão apresentadas e valoradas pelo julgador. Adotamos o posicionamento de que a participação dos interessados no provimento judicial pode ocorrer de três modos distintos, conforme ensina GOMES FILHO: "preventivamente, quando se instaura o contraditório para debater a oportunidade de realizar determinado ato; concomitantemente, quando se manifesta através da atuação na própria prática do ato; ou, ainda, posteriormente, quando consiste em manifestação subsequente ao ato, como, por exemplo, na discussão sobre o valor de uma prova já produzida" ${ }^{\text {40 }}$.

Sob tal ótica, o contraditório prévio refere-se à faculdade concedida às partes de manifestarem-se sobre a prova, antes de sua produção. Embora pouco aludido pela doutrina brasileira, é recorrente no processo penal italiano. Tome-se como exemplo de contraditório prévio, neste país, a possibilidade de oferecimento de quesitos pelos assistentes técnicos designados pelas partes previamente ao ato de produção da prova pericial, mesmo que operado durante as investigações.

O contraditório concomitante (ou real) ocorre quando acusação e defesa são convocados a participarem do ato de realização da prova, normalmente perante a autoridade judicial. Por meio dele é-lhes concedido o direito a exercer o contraditório em tempo real (mediante participação dialética no interrogatório do acusado, na colheita da prova testemunhal, nos reconhecimentos e nas acareações), seja no julgamento, seja nos incidentes processuais de antecipação da prova.

Na modalidade diferida (ou postergada) garante-se o contraditório em situações nas quais a presença do réu ou seu defensor no ato de produção de prova é inviável. Segundo FERNANDES, tratam-se de medidas "que, por sua especialidade, impossibilitem a participação do investigado, como as perícias sobre vestígios que desparecem em tempo

\footnotetext{
${ }^{40}$ In: GOMES FILHO, Antonio Magalhães. Direito à prova no Processo Penal, Revista dos Tribunais: São Paulo, 1997, p. 138-139.
} 
curto, e por isso, requerem exame urgente. Entre nós, essas medidas e as perícias são, em regra, determinadas durante a investigação sem a audiência do suspeito ou indiciado e sem a participação do advogado. A observância do contraditório é feita depois, dando-se oportunidade ao acusado de, no processo, contestar a providência restritiva ou de combater a prova pericial realizada no inquérito" ${ }^{\text {" } 1 .}$

Fato é que a Constituição Federal brasileira não assina validade às provas que desrespeitem o contraditório, em nenhuma hipótese. De acordo com a carta maior, todas as provas, sem exceção, devem se submeter à contradita das partes, mesmo que a posteriori (em situações excepcionais) para que sejam válidas.

$\mathrm{Na}$ Itália o procedimento é diverso. Neste país, embora o contraditório seja previsto como regra, a constituição acomoda exceções à garantia (quando houver concordância do acusado, conduta ilícita ou impossibilidade objetiva).

\subsection{O livre convencimento motivado}

Reza o inciso IX do artigo 93 da carta maior que "todos os julgamentos dos órgãos do poder judiciário serão públicos e fundamentadas todas as suas decisões, sob pena de nulidade". O artigo 111 da Constituição italiana assemelhadamente dispõe que "todas as decisões judiciais deverão ser motivadas". Tais normas, associadas ao que dispõem o artigo 155 do Código de Processo Penal e o artigo 192, inciso I do Código de Processo Penal italiano tratam da garantia do livre convencimento motivado.

Foi longo o caminho percorrido para garantir-se que as sentenças judiciais, em especial as criminais, sustentem-se nas provas produzidas no processo e contenham a exposição dos critérios de avaliação utilizados pelo julgador ${ }^{42}$. No decorrer da história, a forma de condução do processo criminal refletiu o nível de aprimoramento social das nações. É possível dizer que a transformação do processo penal foi permeada pela adoção de

\footnotetext{
${ }^{41}$ In: FERNANDES, Antonio Scarance. Processo Penal ...op.cit., $6^{\mathrm{a}}$ ed., p. 63.

${ }^{42}$ CHIAVARIO, Mario. Processo e garanzie della persona, $2^{\mathrm{a}}$ ed., volume 1, Milano: Giuffré, 1982, p. 141.
} 
diferentes sistemas de avaliação das provas. Dentre esses, merecem destaque a íntima convicção $^{43}$, a prova tarifada ${ }^{44}$ e o livre convencimento motivado.

Pelo sistema do livre convencimento motivado, adotado atualmente no Brasil e na Itália, permite-se ao julgador decidir livremente com base no material probatório considerado válido, mediante a obrigatoriedade de fundamentação dos motivos que o levaram à determinada decisão.

\section{Validade das provas e inadmissibilidade de provas ilícitas}

No que respeita à validade do material probatório em que se sustenta o convencimento do julgador, cabem algumas considerações.

A busca pela verdade (dos fatos alegados pelas partes e daqueles relacionados ao próprio crime) deve guiar a atividade judicial, embora não possa ser perquirida a qualquer custo, posto não ser a única finalidade do processo penal. Além dela, pode-se dizer que são objetivos do processo penal a proteção aos valores fundamentais da segurança (do qual advém a aplicação de normas repressivas à conduta ilícita, com o fim de resguardar a sociedade da criminalidade) e da liberdade (que remete à concessão de vasta gama de direitos de defesa ao acusado, a fim de que possa provar sua inocência) ${ }^{45}$. Trata-se de

\footnotetext{
${ }^{43}$ Pelo sistema da íntima conviç̧ão permitia-se ao julgador formar o convencimento sobre a verdade com base em critérios de convicção íntima, sem a necessidade de que sua decisão fosse fundamentada ou amparada nas provas constantes dos autos. Na Itália esteve presente no código penal de Sardenha de 1865, no código de procedimento penal italiano de 1913 e no código de processo penal italiano de 1930 (código Rocco); no Brasil, vigora de modo residual nos processos do Júri, pois a valoração das provas pelos jurados leigos ocorre sem a necessidade de fundamentação de sua convicção.

${ }^{44}$ No sistema da prova tarifada atribuía-se importância distinta para cada uma das provas, de modo que a confissão, então considerada a rainha das provas, podia, por si, sustentar o édito condenatório. Pelo valor probatório absoluto da confissão, aliás, inúmeras injustiças foram cometidas, muitas das quais conseguidas mediante a tortura do suspeito ${ }^{44}$. Previram-no o código de procedimento penal para o reino da Itália de 1807, o código dos juízos penais do reino da Sicília de 1819, o código de procedimento criminal do reino de Sardenha de 1847 e o código de procedimento criminal do ducado de Modena de 1855, dentre outros.

45 "Deve ser observado, aqui, o binômio busca da verdade real e interesse em se respeitar os direitos constitucionais do cidadão. O desrespeito a esses direitos implicaria a negação do próprio Estado de Direito". In: TOURINHO FILHO, Fernando da Costa. Código de Processo Penal Comentado (artigos $1^{\circ}$ ao 393), $13^{a}$ ed. revisada e atualizada, São Paulo, Saraiva, 2010, p. 531.
} 
equação que reflete a necessidade do equilíbrio entre a eficiência e o garantismo no processo penal $^{46}$.

Daí falar-se em verdade processual, ou seja, uma verdade relativa (e não absoluta) sobre os fatos, que encontra limite nas regras de produção e de valoração do material probatório que servirá de suporte ao convencimento do julgador. Ao mesmo tempo em que legitima a decisão judicial, “impede que sejam utilizadas provas ilícitas ou produzidas com violação de princípios que regem o justo processo" ${ }^{, 47}$.

Não é, portanto, toda e qualquer prova que traga informação importante para a correta verificação dos fatos que será admitida para formar o convencimento motivado do julgador. Somente serão consideradas, para efeito da decisão, as provas legais, vale dizer, aquelas produzidas com respeito aos princípios constitucionais e demais regras do ordenamento jurídico.

Dito de outro modo, as provas ilegais são vedadas, não podendo servir ao convencimento motivado do julgador ${ }^{48}$. As provas ilegais podem ser analisadas segundo a natureza de sua proibição: serão ilegítimas quando infringirem normas de direito processual, e, ilícitas quando violarem princípios, garantias constitucionais e demais normas de direito material.

Para cada uma das espécies de provas ilegais há a previsão de determinada sanção. Bem por isso a doutrina tece crítica ao texto do artigo 157 do Código de Processo Penal brasileiro, com redação dada pela Lei $n^{0} 11.690 / 08$, que indistintamente aponta como provas ilícitas “as obtidas em violação a normas constitucionais ou legais". Com a

\footnotetext{
${ }^{46}$ Sobre a eficiência e o garantismo no processo penal, ver: FERNANDES, Antonio Scarance. Reflexos sobre as noções de eficiência e de garantismo no processo penal. In: Sigilo no Processo Penal: eficiência e garantismo. FERNANDES, Antonio Scarance. ALMEIDA, José Raul Gavião de. MORAES, Maurício Zanoide de (coords). São Paulo: Revista dos Tribunais, 2008, p. 09-28.

${ }^{47}$ In: BADARÓ, Gustavo Henrique Ivahy Badaró. Provas atípicas e provas anômalas: inadmissibilidade da substituição da prova testemunhal pela juntada de declarações escritas de quem poderia ser testemunha. In: In: YARSHELL, Flávio Luis; MORAES, Maurício Zanoide (Org.). Estudos em homenagem ... op. cit., p. 343.

${ }^{48}$ Cf. GRINOVER. Ada Pellegrini; GOMES FILHO. Antonio Magalhães; FERNANDES. Antonio Scarance. As nulidades no processo penal, $11^{\mathrm{a}}$ edição revisada, atualizada e ampliada, São Paulo: Revista dos Tribunais, 2009, p. 124.
} 
mencionada definição, o legislador nacional possibilitou a interpretação equivocada de que às provas ilegítimas aplicar-se-ia a mesma sanção prevista para as provas ilícitas ${ }^{49}$.

Outra, no entanto, é a leitura que se deve fazer das regras de valoração das provas no sistema processual penal brasileiro: as provas produzidas com violação às normas procedimentais, como, por exemplo, as irrituais e as anômalas, serão nulas, não produzindo efeitos no processo. E poderão ser refeitas, possibilitando, assim, o aproveitamento da fonte de prova. Distintamente, as provas obtidas ou produzidas com violação a garantias e princípios constitucionalmente assegurados, como, por exemplo, as adquiridas mediante tortura ou violação de domicílio, serão inadmissíveis, devendo ser desentranhadas do processo, se adentrarem nos autos. Nestes casos, a prova obtida ilicitamente deve ser rejeitada, assim como as provas dela decorrentes - ou seja, as provas ilícitas por derivação ${ }^{50}$.

Algumas exceções são excepcionadas da regra da inadmissibilidade das provas ilícitas. As provas ilícitas por derivação são aceitas quando não evidenciado seu nexo de causalidade com a prova originalmente ilícita, e em situações em que puderem advir de fonte independente $^{51}$. Ademais, em nome do princípio favor rei aceita-se, em casos excepcionais, a utilização no processo de prova ilícita que comprove a inocência do

\footnotetext{
49 “Não parece ter sido a melhor opção da Lei $n^{\circ} 11.690 / 08$, ao definir a prova ilícita como aquela 'obtida em violação a normas constitucionais ou legais' (nova redação do art. 157 CPP). A falta de distinção entre a infringência da lei material ou processual pode levar a equívocos e confusões, fazendo crer, por exemplo, que a violação de regras processuais implica ilicitude da prova e, em consequência, o seu desentranhamento do processo. O não cumprimento da lei processual leva à nulidade do ato de formação da prova e impõe a sua renovação, nos termos do art. 573, caput, do CPP". In: GRINOVER. Ada Pellegrini; GOMES FILHO. Antonio Magalhães; FERNANDES. Antonio Scarance. As nulidades ...op. cit., p. 125.

50 “(...) ou seja, aquelas provas, em si mesmo lícitas, mas a que se chegou por intermédio da informação obtida pela prova ilicitamente colhida". In: GRINOVER. Ada Pellegrini; GOMES FILHO. Antonio Magalhães; FERNANDES. Antonio Scarance. As nulidades ...op. cit., p. 132.

${ }^{51} \mathrm{Cf}$. artigo 157 , parágrafos $1^{\circ} \mathrm{e} 2^{\circ}$ do Código de Processo Penal ( $§ 1^{\circ}$ : "São também inadmissíveis as provas derivadas das ilícitas, salvo quando não evidenciado o nexo de causalidade entre umas e outras, ou quando as derivadas puderem ser obtidas por uma fonte independente das primeiras"; $\$ 2$ - "Considera-se fonte independente aquela que por si só, seguindo os trâmites típicos e de praxe, próprios da investigação ou instrução criminal, seria capaz de conduzir ao fato objeto da prova"). Quanto à disposição há entendimento de que a definição de fonte independente contida no $\S 2^{\circ}$ seria inconstitucional: "Parece ter havido aqui uma confusão do legislador entre as exceções da fonte independente e da descoberta inevitável. Assim mesmo, como antes anotado, na situação de inevitable discovery, são circunstâncias especiais do caso concreto (como no exemplo do encontro do cadáver) é que permitem considerar que a prova seria inevitavelmente obtida, mesmo se suprimida a fonte ilícita. Ao contrário disso, o texto legislativo examinado permite que se suponha sempre a possibilidade de obtenção da prova derivada por meios legais, o que esvazia, por completo, o sentido da garantia". In: GRINOVER. Ada Pellegrini; GOMES FILHO. Antonio Magalhães; FERNANDES. Antonio Scarance. As nulidades ...op. cit., p. 134.
} 
acusado: trata-se da aplicação da regra da proporcionalidade na solução de conflito entre princípios.

No processo penal italiano, as provas violadoras de direitos e garantias constitucionais são inadmissíveis. Todavia, são inutilizáveis ${ }^{52}$ ou anuláveis ${ }^{53}$ quando uma ou outra consequência estiver prevista como sanção ao descumprimento de norma processual. Assim, pode a lei prever que determinada prova, embora respeitadora do procedimento estabelecido para sua produção, não possa ser utilizada em casos específicos (por exemplo, no caso em que as provas de fases anteriores do processo são utilizáveis no julgamento com relação ao réu cujo defensor tenha estado presente ao ato de produção, sendo inutilizável com relação aos demais). Por outro lado, a prova que normalmente seria utilizada para amparar decreto condenatório pode conter defeito processual incorrigível, que a torne nula (a exemplo da violação de um dos atos do procedimento estabelecido na lei para a realização do reconhecimento do suspeito) $)^{54}$.

\footnotetext{
${ }^{52}$ Cf. artigo 191, inciso 1 do Código de Processo Penal italiano ("Le prove acquisite in violazione dei divieti stabiliti dalla legge non possono essere utilizzate").

${ }^{53}$ Cf. artigo 177 do Código de Processo Penal italiano ("L'inosservanza delle disposizioni stabilite per gli atti del procedimento è causa di nullità soltanto nei casi previsti dalla legge").

${ }^{54}$ Cf. TONINI, Paolo. A prova ..., op. cit., p.79-82.
} 


\section{CAPÍTULO II. OS FENÔMENOS PROBATÓRIOS DA ETAPA INVESTIGATIVA: TERMINOLOGIA, TRATAMENTO E PROPOSTA DE SISTEMATIZAÇÃO}

\section{Considerações gerais sobre o inquérito policial e sua relação com as provas}

Em sentido amplo, o termo inquérito exprime o ato e o efeito de investigar determinados fatos que devam ser esclarecidos ${ }^{55}$. O inquérito policial consiste na "atividade desenvolvida pela polícia judicial com a finalidade de averiguar o delito e sua autoria" Trata-se de uma das formas de investigação preliminar existentes no ordenamento brasileiro, da qual também fazem parte o inquérito policial militar, o inquérito administrativo em sentido estrito, o inquérito parlamentar e a formação judicial do corpo de delito (nos crimes contra a propriedade imaterial) ${ }^{57}$.

A investigação criminal é presidida por delegado de polícia e tem por escopo reunir informações que darão suporte à convicção do Ministério Público (órgão acusador, autor da ação penal pública) sobre a viabilidade do oferecimento da denuncia criminal, com o que se evitam acusações infundadas ${ }^{58}$.

\footnotetext{
${ }^{55}$ Nesse sentido: DE PLACIDO E SILVA. Vocabulário Jurídico, Rio de janeiro, Forense, 1963, vol. 2, p. 833.

${ }^{56}$ Cf. LOPES JUNIOR. Aury. Sistemas de investigação preliminar no Processo Penal, $4^{\mathrm{a}}$ ed. revisada, atualizada e ampliada, Rio de Janeiro: Lúmen Júris, Rio de Janeiro, 2006, p. 39. O Código de Processo Penal brasileiro não possui dispositivo legal específico que defina o instituto do inquérito policial. A definição ora apresentada decorre do cotejo entre os artigos $4^{\circ}$ e $6^{\circ}$. Importa acrescentar que o artigo 42 da Lei $\mathrm{n}^{\circ} 2.033 / 71$ trouxe a primeira definição legal do que denominou ser o inquérito policial, da forma como ainda hoje o concebemos: "O inquérito policial consiste em todas as diligências necessárias para o descobrimento dos fatos criminosos, de suas circunstâncias e de seus autores e cúmplices, devendo ser reduzido a instrumento escrito". E que o artigo $9^{\circ}$ do atual Código de Processo Penal Militar apresenta o inquérito policial militar como "a apuração sumária de fato, que, nos termos legais, configure crime militar, e de sua autoria (...), cuja finalidade precípua é a de ministrar elementos necessários à propositura da ação penal".

${ }_{57}$ Sobre as formas de persecução prévia concorrentes ao inquérito policial: SAAD, Marta. $O$ direito de defesa no inquérito policial - Coleção Estudos de processo Penal Joaquim Canuto Mendes de Almeida, vol. 9, São Paulo, Revista dos Tribunais, 2004, p. 98-137.

${ }^{58}$ Cf. LOPES JUNIOR, Aury. A crise do inquérito policial: breve análise dos sistemas de investigação preliminar no processo penal. Revista Ibero-Americana de Ciências Penais, Porto Alegre, ano 1, maio-agosto de 2000, p. 59-60.
} 
$\mathrm{Na}$ Itália, diferentemente do Brasil, três são as etapas do processo criminal: as indagini preliminari (investigações preliminares), a udienza preliminari (audiência preliminar) e o dibattimento (audiência de debates orais e julgamento). As investigações preliminares são conduzidas pelo Ministério Público, com o auxílio da polícia judiciária, e servem principalmente, assim como o inquérito policial no Brasil, à busca de elementos informativos para a formação do convencimento do órgão acusador quanto à viabilidade da denúncia. As atividades levadas a cabo pelo órgão acusador são fiscalizadas por um juiz de direito (giudice per la indagini preliminare, denominado pela doutrina pátria de GIP), que cumpre o papel de garante dos direitos fundamentais do suspeito e da legalidade dos atos produzidos nesta etapa do processo.

O inquérito é inquisitivo, pois não há um rito a ser seguido, ou ordem procedimental a ser respeitada. A discricionariedade concedida à polícia quanto ao desenvolvimento das atividades perquiritórias é importante, pois lhe permite escolher o modo de investigar e os instrumentos investigatórios a serem utilizados em cada caso concreto ${ }^{59}$.

Os atos da investigação não são alcançados pela publicidade, própria do processo criminal. Segundo o artigo 20 do Código de Processo Penal, assegura-se "no inquérito o sigilo necessário à elucidação do fato ou exigido pelo interesse da sociedade" ${ }^{60}$.

O sigilo do inquérito pode ter como objetivo impedir que o conteúdo das investigações torne-se acessível a pessoas alheias ao procedimento (sigilo externo) ou àquelas que possuam interesse na causa (sigilo interno). O segredo interno, conforme ensina LOPES JUNIOR, distingue-se em total ou parcial. Será total quando o acesso for negado ao

\footnotetext{
${ }^{59}$ Cf. SAAD, Marta. O direito de...op. cit., p. 155 e SALLES JUNIOR, Romeu de Almeida. Inquérito policial e ação penal: indagações, doutrina, jurisprudência, prática. $6^{\mathrm{a}}$ ed., revisada, ampliada e atualizada, São Paulo, Saraiva, 1992, p. 07.

${ }^{60}$ Complementa-o a Portaria $n^{\circ} 882$ de 11 de novembro de 1951, expedida pela Chefia de Polícia que recomenda aos Srs. Delegados, comissários, escrivães e demais servidores das delegacias que, para a estrita observância do disposto no artigo 20 do Código de Processo Penal, não sejam fornecidos a terceiros quaisquer dados relativos à existência ou não de testemunhas dos fatos registrados no livro de ocorrências, seus nomes e endereços, enquanto não tiverem sido estas e o indiciado ouvidos no inquérito destinado à apuração do fato, ressalvado, às partes, o direito de obterem, por meio de certidão, o inteiro teor dos mesmos registros.
} 
investigado, seu defensor e ao assistente da acusação, e parcial quando limitar o acesso do investigado, mas não de sua defesa técnica ${ }^{61}$.

O êxito de alguns atos da investigação depende do fator surpresa que os circunda. Assim, por exemplo, não será bem sucedida a apreensão de entorpecente se houver a prévia notificação do ato ao suspeito de traficá-lo ou ao seu defensor. Nestes casos, é lícito que seja dado sigilo total ao procedimento.

Também na Itália, as investigações preliminares são, em regra, efetivadas informal e sigilosamente, muito embora o réu e seu defensor devam ser notificados da existência da investigação, quando nela haja a produção de atos que tenham o direito a participar. Notese que a fim de respeitar a paridade de armas e a igualdade entre as partes o legislador italiano concedeu à defesa o direito de efetuar suas próprias investigações preliminares, bem como de requisitar, ao término das investigações do órgão acusador, que este proceda à realização de outras medidas necessárias à comprovação da inocência do suspeito.

Por muito tempo discutiu-se a no Brasil possibilidade de atuação dos mecanismos da ampla defesa na etapa do inquérito, pois "não existe acusação nessa fase, onde se fala em indiciado (e não acusado, ou réu) ${ }^{, 62}$.

Hoje não remanescem dúvidas quanto à admissibilidade ${ }^{63}$ da defesa técnica na etapa préprocessual. Em linhas gerais, o suspeito pode requerer diligências à autoridade policial, pleitear o relaxamento do flagrante (ou, quando não cabível, solicitar a liberdade provisória), impetrar Habeas Corpus e, no que diz respeito aos atos restritivos de sua liberdade, ser obrigatoriamente assistido por advogado. Podem ser citados como exemplos de aceitação da atuação da defesa técnica no inquérito os artigos $306, \S 1^{\circ}$ ("em até 24 horas após a realização da prisão, será encaminhado ao juiz competente o auto de prisão em flagrante e, caso o autuado não informe o nome de seu advogado, cópia integral para a Defensoria Pública") e 335 ("recusando ou retardando a autoridade policial a concessão da fiança, o preso, ou alguém por ele, poderá prestá-la, mediante simples

${ }^{61}$ Cf. LOPES JUNIOR. Aury. Sistemas de ...op. cit., $4^{\mathrm{a}}$ ed., p. 126-136.

${ }^{62}$ In: CINTRA, Antônio Carlos de Araújo; GRINOVER, Ada Pellegrini; DINAMARCO, Cândido Rangel. Teoria Geral do Processo, 22 ${ }^{\mathrm{a}}$ ed. revisada e atualizada, São Paulo: Malheiros, 2006, p. 63.

${ }^{63} \mathrm{Cf}$. artigo $7^{\circ}$ do estatuto da Advocacia - Lei n ${ }^{\circ}$ 8906/94. 
petição, perante o juiz competente, que decidirá em 48 horas") do Código de Processo Penal brasileiro, com redação dada pela Lei n ${ }^{\circ} 12.403$ de 2011.

Diz-se, todavia, não haver contraditório nesta etapa processual em decorrência da Constituição Federal ser clara em afirmar, no artigo $5^{\circ}$, inciso LV, que a garantia é afeta "aos acusados em geral",64. Assim, a inexistência de acusação formal impede que sejam efetuados grandes debates entre defesa e acusação, que costumam ser postergados para a fase judicial propriamente dita.

Os autos do inquérito abarcam todas as informações com potencial conteúdo probatório coletadas nas investigações. Neles há informações que servem ao oferecimento da denúncia e à fundamentação de prisões e outras medidas restritivas de direitos. Algumas das provas obtidas nesta etapa devem ser repetidas em juízo para que sejam válidas; outras não poderão submeter-se à nova produção durante a instrução judicial, em razão de características próprias, que lhes impigem transitoriedade ou por circunstâncias até então imprevisíveis. De qualquer modo, todo o material probatório constante do inquérito ingressa nos autos do processo, por ocasião do oferecimento da denúncia. E essa circunstância permite ao julgador tomar contato com provas que, muitas vezes, não são produzidas em contraditório e com respeito ao procedimento probatório previsto em lei.

De modo distinto, na Itália seleciona-se o material probatório produzido na fase das investigações, de modo que se formam três autos independentes com finalidades distintas no processo: os autos do Ministério Público (que conterão informações das investigações que não poderão ser valoradas pelo julgador, exceto se ingressarem no processo, na fase de debates, em razão de permissivo legal), os autos da defesa (compostos pelo conteúdo das investigações preliminares por ela realizados e pela ata dos atos levados a cabo pela acusação, dentre os quais aqueles cuja produção tenha sido por ela requerido) e o arquivo de provas a serem utilizadas no julgamento (fascicolo per il dibattimento), cujo conteúdo é formado pela decisão do recebimento da denúncia, pelo rol de testemunhas a serem ouvidas em juízo e por provas não repetíveis e/ou antecipadas.

\footnotetext{
${ }^{64}$ In: CINTRA, Antônio Carlos de Araújo; GRINOVER, Ada Pellegrini; DINAMARCO, Cândido Rangel. Teoria Geral...op. cit., p. 63.
} 
Até o ano de 2008 não havia norma no processo penal brasileiro que regulamentasse o uso das provas produzidas na etapa do inquérito. Em razão da omissão legislativa, a doutrina buscou estabelecer um regramento geral, segundo o qual se distinguem os atos próprios da investigação daqueles que consubstanciam provas: "É preciso inicialmente distinguir os atos propriamente de investigação dos atos que, apesar de realizados nessa fase, têm valor probatório ou podem, segundo o sistema de determinado país, servir à instrução da causa e ao convencimento do juiz",65.

Segundo LOPES JUNIOR ${ }^{66}$ os atos de investigação (ou de instrução preliminar) seriam os que estão a serviço do inquérito e do cumprimento de seus objetivos (como a demonstração do fumus commissi delicti necessário para justificar o processo e, antes dele, a formação da opinio delicti do acusador), que servem como fundamento para decisões interlocutórias de indiciamento, adoção de restrições provisórias a direitos, e que não exigem a estrita observância dos princípios da publicidade, imediação e contraditório. Os atos de prova, por sua vez, seriam os que, mesmo praticados na fase inquisitiva da persecução penal, dirigemse à formação de um juízo de certeza, que estejam a serviço do processo (e não do inquérito) e de seus fins (como a atividade de sentenciar), que sejam praticados sob a presidência de juiz e que exijam a observância do contraditório.

Embora predominasse na doutrina o entendimento de que os atos de investigação não poderiam ser utilizados na formação do convencimento do julgador, a jurisprudência firmou-se no sentido de que, fossem os atos de investigação corroborados por provas produzidas em juízo, poderiam compor o conjunto de provas válidas do processo.

Em 2008 foi aprovada a Lei $\mathrm{n}^{\mathrm{o}} 11.690$, que alterou o artigo 155 do Código de Processo Penal, passando a prever que o "juiz formará sua convicção pela livre apreciação da prova produzida em contraditório judicial, não podendo fundamentar sua decisão exclusivamente nos elementos informativos colhidos na investigação, ressalvadas as provas cautelares, não repetiveis e antecipadas".

\footnotetext{
${ }^{65}$ In: FERNANDES, Antonio Scarance. A reação defensiva à imputação, São Paulo: Revista dos Tribunais, 2002, p. 132-133.

${ }^{66}$ LOPES JUNIOR. Aury. Sistemas de ...op. cit., $4^{\mathrm{a}}$ ed., p. 137-138.
} 
Da leitura da norma infere-se que o legislador congregou elementos informativos, provas cautelares, provas antecipadas e provas não repetíveis como fenômenos probatórios da etapa investigativa. Não lhes atribuiu, todavia, significado. Também resta claro que houve a normatização do entendimento de que provas não repetíveis podem ser utilizadas de modo não exclusivo no convencimento do julgador. Porém o legislador não estabeleceu parâmetros para seu uso.

\section{Terminologia aplicável aos fenômenos probatórios da fase investigativa}

\subsection{Provas não repetíveis}

Ao utilizar a expressão provas não repetiveis no artigo 155 do Código de Processo Penal o legislador pátrio não definiu em que consistiria o fenômeno da irrepetibilidade probatória.

O verbo repetir possui nas mais diversas línguas (répéter no francês, to repeat no inglês, wiederholen no alemão, herhalen no holândes, ripetere no italiano e repetir no espanhol) o comum significado de redizer, refazer, ratificar, reproduzir, reiterar. No sentido inverso, portanto, tudo quanto não possa ser redito, refeito, ratificado, reproduzido ou reiterado será irrepetível.

Mas ressalta a doutrina ${ }^{67}$ que o vocábulo irrepetível (e seus sinônimos não repetível e nãorepetível, também adotados pela comunidade jurídica) aplicado ao termo prova na seara do processo penal não tem a força dos significados empregados na linguagem comum. A prova criminal nunca poderia ser genuinamente repetida, isto é, reproduzida com fidelidade, pois isso pressuporia a existência da mesma conjuntura que permeou a colheita original da prova, a imutabilidade da fonte da qual emana a prova e a garantia do mesmo

\footnotetext{
${ }^{67} \mathrm{Cf}$. VICENTE GRECO FILHO ("deixamos de discutir o defeito de terminologia, uma vez que prova nunca se repete; pode haver uma segunda perícia sobre o mesmo objeto, mas a segunda não é repetição da primeira; a testemunha ouvida no inquérito será ouvida em juizo, porém o depoimento judicial não é repetição do primeiro". In: Manual de Processo Penal, $8^{a}$ edição revista, atualizada e ampliada, São Paulo: Saraiva, 2010, p. 204-205).
} 
resultado $^{68}$. Tecnicamente, nunca há repetição, mas uma nova produção de prova, sobre a mesma fonte (que pode ou não ter conservado as características que apresentava quando submetida à primeira apreciação), em diferentes circunstâncias fáticas e temporais, podendo ou não levar ao resultado de prova alcançado da primeira vez.

É possível, assim, observar-se que a viabilidade de produção de determinada prova na audiência de julgamento é correlata à capacidade de perenidade da fonte da qual ela emana ${ }^{69}$. Em outros termos, perdurando o objeto ou a pessoa (fontes de prova) até a etapa da instrução criminal e estando eles em condições de trazerem para o bojo do processo informações (elementos probatórios) úteis ao deslinde da causa, a prova será repetível.

Feitas tais observações, propomos definir como irrepetível a prova cuja fonte (pessoa ou objeto) não puder ser submetida a exame na audiência de julgamento, em razão de alteração significativa das características que lhe são peculiares, ou de sua extinção. Tratase de conceito amplo, que comporta classificações. Estas serão feitas ao final do capítulo, após o estabelecimento das premissas necessárias à sua compreensão.

\subsection{Elementos informativos}

Elementos informativos são os dados coletados durante as investigações com o escopo primário de fornecer ao órgão acusador as informações necessárias à propositora da ação penal, ou ao seu arquivamento. Sua função residual é a de dar suporte à decretação de prisões e outras medidas restritivas de direito.

Entendemos que os elementos informativos ligam-se à fonte de prova repetível: são informações extraídas da fonte (pessoa ou objeto) que, a princípio, será submetida à nova

\footnotetext{
68 "Por repetição entendemos a nova realização ou declaração de algo que já se disse ou se fez. A repetição exige que a pessoa que originariamente praticou o ato volte a realizá-lo da mesma forma". In: LOPES JUNIOR, Aury. Direito Processual Penal e sua Conformidade Constitucional, $3^{\text {a }}$ ed. revisada e atualizada, vol. I, Rio de Janeiro: Lumen Juris, 2008, p. 302.

${ }^{69}$ No mesmo sentido: FEITOZA (Direito processual penal: teoria, crítica e práxis, $6^{\mathrm{a}}$ ed., Niterói: Impetus, 2009, p. 691) e ARANTES FILHO (A interceptação de comunicações de pessoas presentes como meio de investigação de prova no direito processual penal. Dissertação de Mestrado em Direito Processual, Universidade de São Paulo, 2010, p. 57).
} 
produção de prova na instrução criminal. Mas repita-se, embora os elementos informativos consubstanciem informações extraídas de uma fonte de prova, "não constituem, a rigor, provas no sentido técnico-processual do termo, mas informações de caráter provisório, aptas somente a subsidiar a formulação de uma acusação perante o juiz ou, ainda, servir de fundamento para a admissão dessa acusação e, eventualmente, para a decretação de alguma medida de natureza cautelar" 70 .

Em outras palavras, não são elementos de prova, ou seja, “dados objetivos que confirmam ou negam uma asserção a respeito de um fato que interessa à decisão da causa" "71, haja vista as circunstâncias de sua formação - sob a presidência da autoridade policial (e não judicial), sem que se possibilite o contraditório entre as partes, em procedimento cujo controle da legalidade não é possível.

O valor probatório dos elementos informativos é reduzido ${ }^{72}$ : se convergentes, poderão ser suficientes à comprovação da materialidade delitiva, mas nunca da autoria ${ }^{73}$, que deverá ser provada em juízo, por meio da utilização de elementos de prova.

Uma análise apressada poderia sugerir que os elementos informativos corporificam-se no conjunto de atividades policias referidas nos artigos $6^{\circ}$ e $7^{\circ}$ do Código de Processo Penal, vale dizer, averiguação da vida pregressa do suspeito, identificação datiloscópica do indiciado, corpo de delito, objetos apreendidos que se relacionem ao crime, oitiva do ofendido, de testemunhas e do indiciado, eventuais reconhecimentos, acareações, perícias e reconstituições e outras provas que tiverem relação com os fatos criminosos.

Parece-nos, todavia, que as atividades levadas a cabo durante as investigações extrapolam a produção de meros elementos informativos, ou seja, de dados que serviriam primordialmente à propositora da ação penal. Podemos adiantar que algumas das

\footnotetext{
${ }^{70}$ In: BADARÓ, Gustavo Henrique Righi Ivahy. Direito processual penal, tomo 1, Rio de Janeiro: Elsevier, 2008, p. 63.

${ }^{71}$ GOMES FILHO, Antonio Magalhães. Notas sobre a terminologia ... op. cit., p. 307.

72 "Os elementos de informação não são colhidos sob a égide do contraditório e da ampla defesa, nem tampouco na presença do juiz de direito. Assim, a confissão extrajudicial, por exemplo, terá validade como elemento de conviç̧ão do juiz apenas se confirmada por outros elementos colhidos durante a instrução processual”. CAPEZ, Fernando. Curso de Processo Penal. 4a ed., São Paulo: Saraiva, 1999, p. 70.

73 A reunião de elementos informativos trará apenas indícios da autoria, suficientes ao oferecimento da denúncia.
} 
informações adquiridas na persecução prévia resultam da produção de provas cautelares (em sentido amplo) e não repetíveis; outras, por sua vez, decorrem de atividade probatória extravagante (vale dizer, desnecessária ao oferecimento da denúncia), que bem poderia ser realizada somente em juízo.

A doutrina brasileira tece críticas quanto à excessiva atividade probatória desenvolvida na etapa do inquérito policial. LOPES JUNIOR explica que as informações arrecadadas no inquérito deveriam provir de uma cognição sumária, ou seja, "limitada ao imprescindivel, já que se quer reservar para a fase processual o conhecimento de dados complementários, assim como a verificação exaustiva do anteriormente apurado, proporcionando ao julgador o convencimento da exatidão e certeza dos mesmos"74. Isto porque "o espírito comum dos sistemas jurídicos atuais é limitar a investigação preliminar à atividade mínima de comprovação e averiguação do fato e da autoria, para justificar o processo (exercício da ação penal) ou o não-processo (arquivamento)"75.

\subsection{Provas cautelares lato sensu: provas antecipadas e provas cautelares stricto sensu}

Por meio do processo criminal desenvolve-se a atividade jurisdicional que busca legitimar o jus puniendi do Estado. Trata-se de procedimento desenvolvido de forma lenta e gradual, a fim de assegurar ao acusado que sua eventual condenação dar-se-á dentro dos parâmetros do devido processo legal. A delonga do processo criminal, todavia, não pode obstar os fins do próprio processo, devendo-se perquirir o equilíbrio entre a eficiência e o garantismo: de um lado, o processo deve desenvolver-se cuidadosamente, de modo a assegurar os direitos

\footnotetext{
${ }^{74}$ LOPES JUNIOR, Aury. Sistemas de ...op. cit., $1^{\text {a }}$ ed., p. 94 . Segundo o mesmo autor, a sumariedade da cognição, desejada na fase da investigação policial, pode ser feita de forma qualitativa (quer dizer, de modo a limitar o conteúdo a ser investigado), quantitativa (quando o ordenamento jurídico adota um limite temporal para a duração da fase investigativa) ou mista (quando a legislação prevê ambas a um só tempo) (idem, p. 112). Ressalte-se que no Brasil a limitação possui apenas o caráter quantitativo (artigo 10 do Código de Processo Penal e artigo 66 da Lei $\mathrm{n}^{\circ}$ 5010/66), diferentemente do que ocorre em Itália, onde as investigações são limitadas qualitativa e quantitativamente (artigos 236 e 405, inciso 2 do Código de Processo Penal italiano).

${ }^{75}$ LOPES JUNIOR. Aury. Sistemas de ...op. cit., $1^{\text {a }}$ ed., p. 94. Segundo GRECO FILHO, com exceção das provas que devam ser produzidas cautelarmente, "as provas orais devem ser produzidas em audiência ou audiências. A pericial na fase policial ou em juízo. A documental a qualquer tempo, respeitada a oportunidade de contraditório" (In: GRECO FILHO, Vicente. Manual de ...op. cit., p. 197).
} 
individuais de suspeitos e acusados; de outro, deve garantir a produção das provas necessárias à consecução de uma decisão justa.

Decorre disso a possibilidade de utilização de mecanismos de preservação de provas que servem à motivação da sentença, mas que não poderiam aguardar para que fossem produzidas na audiência de debates e julgamento ${ }^{76}$. Trata-se da produção cautelar de provas no processo penal.

A atividade probatória cautelar não apresenta contornos bem delineados no Código de Processo Penal. Em razão disto, doutrinadores socorrem-se da lei processual civil, por analogia, na tentativa de delimitar o instituto. O fazem em razão de haver, nesta área, farta legislação sobre o processo cautelar e as medidas cautelares incidentais.

Foi, aliás, no processo civil que se travaram debates interessantes sobre cautelaridade, encabeçados por Giussepe Chiovenda, Francesco Carnelutti e Piero Calamandrei. Não é, todavia, fácil a tarefa de estender ao processo penal os conceitos de cautelaridade adotados no processo civil - embora em ambas as áreas as cautelares sirvam ao resguardo da demanda principal ${ }^{77}$.

PITOMBO, ao analisar a aplicabilidade, no processo penal, do conceito de cautelares do processo civil, diz que a comparação "mostra-se limitada, em razão da dificuldade e quase impossibilidade de transposição dos conceitos civilistas para o processo penal" ${ }^{, 78}$. Entendemos, assim como a autora, que em razão das diferenças substanciais entre as duas espécies de processo, civil e criminal (a começar pelo fato de que no processo penal não há lide propriamente dita: o interesse do acusado é contraposto ao da sociedade e as cautelares limitam, no mais das vezes, garantias constitucionais àquele asseguradas), o processo penal pede uma sistematização própria das medidas cautelares, adequada aos seus fins.

\footnotetext{
${ }^{76} \mathrm{O}$ atuar da polícia judiciária, além de proporcionar a reunião de elementos investigativos necessários à preparação da ação penal pelo órgão acusador, evita o desaparecimento de importantes elementos de prova que não poderiam esperar para que fossem produzidos durante a instrução judiciária. Trata-se da função cautelar que a esta (polícia) é confiada no momento pré-processual da persecutio criminis. Cf. MARQUES, José Frederico. Elementos de direito processual penal, $2^{\mathrm{a}}$ ed., vol. 1, Rio de Janeiro, Forense, 1965, p. 150151.

${ }_{77}$ Cf. RANGEL, Paulo. Direito Processual Penal. 14 a ed, Rio de Janeiro: Lumen Juris, 2008, p. 585-586.

${ }^{78}$ In: PITOMBO, Cleunice A. Valentim Bastos. Da busca e da apreensão no processo penal. Dissertação de mestrado apresentada à Faculdade de direito da Universidade de São Paulo, São Paulo, 1997, p. 198.
} 
Partimos da premissa de que existem três espécies de medidas cautelares no processo penal: cautelares pessoais ${ }^{79}$, cautelares reais ${ }^{80}$ e cautelares relativas às provas ${ }^{81}$.

São as cautelares relativas às provas que interessam ao estudo da irrepetibilidade probatória. Estas se destinam a "assegurar a eficiência da atividade probatória, diante do risco de que a ação do tempo impeça ou dificulte que pessoas ou coisas possam servir como fonte de prova" ${ }^{82}$. Ligam-se, deste modo, a fontes de prova, a princípio, não repetíveis.

É notória a confusão terminológica que circunda as expressões prova cautelar e prova antecipada no processo penal, embora ambas propiciem "justamente a antecipação da formação da prova" ${ }^{" 83}$. Ora são entendidas como expressões sinônimas ${ }^{84}$, ora como institutos estanques ${ }^{85}$.

\footnotetext{
${ }^{79}$ As medidas cautelares pessoais são utilizadas para promover a restrição provisória da liberdade de suspeitos, durante as investigações, e de acusados em geral, antes do trânsito em julgado da sentença penal condenatória. Estão previstas no título IX (da prisão, das medidas cautelares e da liberdade provisória) do Código de Processo Penal brasileiro, recentemente alterado pela Lei $\mathrm{n}^{\circ} 12.403 / 11$, a prisão em flagrante, a prisão preventiva, a prisão domiciliar, o comparecimento periódico em juízo, a proibição de acesso ou frequência a determinados lugares, a proibição de manter contato com pessoa determinada, a proibição de ausentar-se da comarca, o recolhimento domiciliar suspensão do exercício de função pública ou de atividade de natureza econômica ou financeira, a internação provisória do acusado, a fiança e a monitoração eletrônica. Em lei esparsa, ainda, a prisão temporária (Lei no 7960/89). O Código de Processo penal italiano descreve as misure cautelari personali no livro IV, título I (artigos 272 a 315). Interessante posicionamento é encontrado na doutrina italiana quanto à prisão em flagrante e a detenção de suspeito. Segundo explica CHIAVARIO, tratar-se-iam de medidas pré-cautelares (e não propriamente cautelares) pessoais, por referirem-se à prisão efetuada por agentes policiais (ou pelo Ministério Público) antes da concessão de autorização judicial (que é condição sine qua non da cautelaridade), dependentes, portanto, da posterior convalidação pelo magistrado. CHIAVARIO, Mario. Diritto Processuale Penale, $4^{\mathrm{a}}$ ed., Milano: Utet Giuridica, 2010, p. 617-629.

${ }^{80}$ As medidas cautelares reais restringem o patrimônio de suspeitos e acusados com o fim de possibilitar, após a condenação criminal, a reparação do dano à vítima, o adimplemento da pena pecuniária e o pagamento de custas processuais. Estão previstas no Código de Processo Penal brasileiro o sequestro (artigos 125, 126 e 127), a especialização de hipoteca legal (artigo 134) e o arresto (artigo 137). No Código de Processo penal italiano são misure cautelari reali, previstas no livro IV, título I (artigos 316 a 325), o sequestro conservativo e o preventivo.

${ }^{81}$ Cf. FERNANDES, Antonio Scarance. Processo Penal ...op.cit., $6^{a}$ ed., p. 299.

${ }^{82}$ In: GOMES FILHO, Antonio Magalhães. Provas: Lei 11.690, de 9.6.2008. In: MOURA, Maria Thereza Rocha de Assis. (Org.). As reformas...op. cit., p. 252.

${ }^{83}$ In: GOMES FILHO, Antonio Magalhães. Provas: Lei 11.690, de 9.6.2008. In: MOURA, Maria Thereza Rocha de Assis. (Org.). As reformas...op. cit., p. 253.

84 "Pergunta-se, o que são provas cautelares que não sejam antecipadas? Ou, ao contrário, as antecipadas que não sejam cautelares?” In: GRECO FILHO, Vicente. Manual de ...op. cit., p. 204.

${ }^{85}$ São assim apontadas pelo legislador brasileiro no artigo 155 do Código de Processo Penal.
} 
Apoiamo-nos no entendimento de que provas cautelares (stricto sensu) e provas antecipadas são espécies do mesmo gênero (provas cautelares lato sensu) ${ }^{86}$. Pertencem ao mesmo gênero porque visam (mesmo que de maneiras diferentes) resguardar provas que não poderiam ser obtidas na audiência de julgamento. Todavia, referem-se a situações distintas: as provas antecipadas servem à obtenção de elementos de prova, enquanto as provas cautelares (stricto sensu) à obtenção de fontes de prova.

As provas cautelares em sentido estrito podem ser definidas como os meios de investigação executados pela polícia (ou outros auxiliares da justiça) na etapa préprocessual, mediante autorização judicial, com a finalidade de perquirir fontes de prova.

A produção antecipada da prova refere-se à utilização de certos meios de produção de prova $^{87}$ em momento anterior à audiência de julgamento. Sua finalidade é a de resguardar elementos de prova que poderiam perder-se, caso não fossem extraídos da fonte de prova (pessoa ou objeto), cuja alteração ou extinção seja previsível.

O artigo 156 do Código de Processo Penal trata dos requisitos de admissibilidade das provas cautelares (lato sensu). Segundo o artigo, poderão ser produzidas cautelarmente provas urgentes e relevantes, a um só tempo. A urgência a que alude o artigo de lei trata da identificação do periculum in mora, ou seja, da necessidade da constatação judicial de que eventual retardo na prestação jurisdicional inviabilizaria a obtenção de fonte de prova (prova cautelar stricto sensu) ou de elemento de prova (prova antecipada) importante para o processo.

\footnotetext{
86 "o que o legislador pretendeu certamente sublinhar com a variação de nomenclatura, foi que há situações mais gerais em que os atos de formação de prova são realizados cautelarmente, independentemente da observância do contraditório, e em outros casos em que a antecipação ocorre já com relação processual instaurada, com necessária participação das partes" (In: GOMES FILHO, Antonio Magalhães. Provas: Lei 11.690, de 9.6.2008. In: MOURA, Maria Thereza Rocha de Assis. (Org.). As reformas...op. cit., p.253). Vicente Greco Filho, na mesma linha, aduz ser possivel tentar-se fazer uma distinção entre a prova cautelar e a antecipada, entendendo-se esta como a decorrente do procedimento próprio cautelar de produção antecipada de prova e as outras colhidas sem audiência do possivel ou hipotético acusado em virtude da urgência de sua colheita, como o levantamento do local, o exame necroscópico e outras perícias (In: GRECO FILHO, Vicente. Manual de ...op. cit., p. 204).

${ }^{87}$ Cf. o artigo 846 do Código de Processo Civil, são meios de produção de prova passíveis de antecipação o interrogatório da parte, a inquirição de testemunhas e o exame pericial. O rol, todavia, não é taxativo, podendo ser ampliado no processo penal, em razão de nesta área do direito existirem meios de prova não utilizáveis no processo civil (a exemplo dos reconhecimentos e das acareações).
} 
A relevância decorre da verificada indispensabilidade da prova para a solução do processo. É a constatação do fumus boni iuris, que se traduz num juízo de verossimilhança feito pelo magistrado: se entender importante a prova e fidedignos os motivos justificadores do requerimento de antecipação, autorizará a cautela.

Ainda conforme o artigo 156 do Código de Processo Penal, a autorização judicial concessiva da produção cautelar de prova deve ser feita com base nos critérios da necessidade, adequação e proporcionalidade da medida. Assim, para ser autorizada, a prova deve, concomitantemente: (i) ser imprescindível ao processo (necessidade); (ii) ser produzida por um meio apropriado de produção ou de investigação de prova (adequação); e (iii) decorrer da ponderação entre os benefícios os malefícios advindos da antecipação da prova no caso concreto (proporcionalidade).

\section{Análise da disciplina normativa autorizadora das provas não repetíveis}

\subsection{O artigo 155 do Código de Processo Penal e seu trâmite legal no Brasil}

O Código de Processo Penal (Decreto-Lei $\mathrm{n}^{\mathrm{o}} 3.689$ ), ainda hoje em vigor, foi promulgado em 1941 com vistas a servir aos anseios da sociedade brasileira daquela época. Desde então, embora diversas tenham sido as tentativas de sua revogação com a consequente implementação de um novo $\operatorname{codex}{ }^{88}$, nenhuma das propostas de reforma global da lei processual penal vingou.

Verifica-se que as adaptações da lei processual penal brasileira aos princípios constitucionais em voga decorreram de reformas pontuais na legislação, efetuadas pelo poder legislativo com o auxílio e orientação de juristas - esses responsáveis pela provisão do suporte técnico necessário à compreensão dos temas passíveis de alteração legal. Em um contexto de reformas pontuais nasceu, em 2008, a Lei $\mathrm{n}^{\mathrm{o}} 11.690 / 08$, que alterou o artigo 155 e outros dispositivos legais do Código de Processo Penal.

\footnotetext{
${ }^{88}$ Como a proposta do Projeto de Lei no $8045 / 10$, que tramita atualmente na Câmara dos Deputados.
} 
Desde a década de 1990 fomentavam-se discussões doutrinárias sobre a necessidade de alteração de normas processuais penais relativas às provas, às medidas cautelares, aos procedimentos (em especial ao Júri) e aos recursos. Foi em razão disso que, em 20 de janeiro de 2000, o então Ministro da Justiça José Carlos Dias, por meio da portaria $\mathrm{n}^{\mathrm{o}} 61^{89}$, instituiu uma comissão de juristas ${ }^{90}$ para elaborar propostas de alteração de dispositivos do Código de Processo Penal, a fim de adequá-los ao panorama jurídico-social da época.

A comissão entregou ao Ministério da Justiça, em dezembro do mesmo ano, sete anteprojetos (com as respectivas exposições de motivos) que propunham as alterações legais a serem promovidas no Código de Processo Penal. Os anteprojetos foram acatados pelo poder executivo e convertidos, na Câmara dos Deputados, nos Projetos de Lei ${ }^{o}$ 4.203/01 (Júri), $\mathrm{n}^{\mathrm{o}} 4.204 / 01$ (interrogatório e defesa legítima), $\mathrm{n}^{\mathrm{o}} 4.205 / 01$ (provas), $\mathrm{n}^{\mathrm{o}}$ 4.206/01 (recursos), $n^{\circ} 4.207 / 01$ (suspensão do processo e procedimentos), $n^{\circ} 4.208 / 01$ (prisão, medidas cautelares e liberdade) e no 4.209/01(investigação criminal).

$\mathrm{Na}$ exposição de motivos do anteprojeto referente às provas, a comissão teceu esclarecimentos sobre a necessidade de vedação legal do uso de elementos informativos colhidos no inquérito para a formação da convicção do julgador, em razão de sua utilização ser incompatível com a garantia constitucional do contraditório. Enfatizou, ainda, serem utilizáveis as provas produzidas antecipadamente, as provas cautelares e as provas não repetíveis, passíveis de contraditório (mesmo que diferido):

“A Constituição de 1988, ao garantiraos litigantes, em processo judicial ou administrativo, e aos acusados em geral o contraditório e a ampla defesa (art. $5^{\circ}$, inciso $L V)$, assegura às partes a participação efetiva nas atividades processuais, especialmente aquelas em que se forma o material probatório que servirá de base para a decisão. Por esse motivo, o anteprojeto propõe nova redação ao art. 155 do Código de Processo Penal, deixando bem claro que não podem ser reconhecidos como provas - e, portanto, capazes de servir à formação do convencimento judicial - os elementos

\footnotetext{
${ }^{89}$ Ratificada mais tarde pela portaria $\mathrm{n}^{\circ} 371 / 2000$.

${ }^{90}$ Composta por Ada Pellegrini Grinover (que a presidiu), Petrônio Calmon Filho (que a secretariou), Antônio Magalhães Gomes Filho, Antônio Scarance Fernandes, Luiz Flávio Gomes, Miguel Reale Júnior, Nilzardo Carneiro Leão, René Ariel Dotti (posteriormente substituído por Rui Stoco), Rogério Lauri Tucci e Sidney Beneti.
} 
colhidos sem aquelas garantias, como ocorre em relação aos dados informativos trazidos pela investigação, que devem servir exclusivamente à formação da opinio delicti do Ministério Público e à concessão de medidas cautelares pelo juiz. Excetuam-se apenas as provas produzidas antecipadamente, as cautelares e as irrepetiveis, sobre as quais se estabelecerá o contraditório posterior" ${ }^{91}$.

Foi originalmente proposto pela comissão o seguinte texto para o artigo 155 do Código de Processo Penal: “O juiz formará sua convicção pela livre apreciação da prova produzida em contraditório judicial, não podendo fundamentar sua decisão nos elementos informativos colhidos na investigação, ressalvadas as provas cautelares, irrepetíveis e antecipadas". Ele foi apresentado, juntamente com o Projeto de Lei n ${ }^{\circ} 4205 / 2001$, na Câmara dos Deputados em 12 de março de 2001.

Houve certa resistência dos legisladores à redação originalmente apresentada. Os deputados entenderam que, ao proibir que o juiz levasse em conta os elementos informativos do inquérito, até então utilizados supletivamente na decisão, estar-se-ia supondo que o magistrado não seria responsável o suficiente para sopesar livremente o conjunto probatório e prestar-lhe a devida valoração, sendo preciso vedar-lhe tal prerrogativa $^{92}$. Haveria, segundo tal orientação, prejuízo ao princípio da livre convicção motivada $^{93}$.

${ }^{91}$ Disponível em: http://www.pesquisedireito.com/provas.htm, acesso em 10 de fevereiro de 2012.

${ }^{92}$ A crítica amoldava-se à exposição de motivos do Código de Processo Penal, publicada no diário oficial de 13 de outubro de 1941: " $n$ ão serão atendiveis as restrições à prova estabelecidas na lei civil, salvo quanto ao estado das pessoas; nem é prefixada uma hierarquia de provas: na livre apreciação destas, o juiz formará, honesta e lealmente, a sua convicção. A própria confissão do acusado não constitui, fatalmente, prova plena de sua culpabilidade. Todas as provas são relativas; nenhuma delas terá, ex vi legis, valor decisivo ou necessariamente maior prestígio que outra. Se é certo que o juiz fica adstrito às provas constantes dos autos, não é menos certo que não fica subordinado a nenhum critério apriorístico no apurar, através delas, a verdade material. O juiz criminal é, assim, restituído á sua própria consciência. Nunca é demais, porém, advertir que livre convencimento não quer dizer puro capricho de opinião ou mero arbitrio na apreciação das provas. O juiz está livre de preconceitos legais na aferição das provas, mas não pode abstrair-se ou alhear-se ao seu conteúdo. Não estará ele dispensado de motivar a sua sentença. E precisamente nisto reside a suficiente garantia do direito das partes e do interesse social" (...).

${ }^{93}$ Cf. Deputado Luiz Antonio Fleury Filho, em 12/03/2002: "Em que pese o respeito e a admiração que temos pelos juristas que elaboraram o Projeto de Lei enviado pelo Poder Executivo, bem como o profundo conhecimento do ilustre Relator, Deputado Ibrahim Abi-Ackel, referência desta Casa em matéria de Direito, permito-me sugerir algumas alterações ao texto proposto, que, salvo melhor juizo, poderão contribuir para a celeridade da resposta do Estado à prática do crime. O artigo 155, 'caput' merece ser modificado, adotando-se a seguinte redação: 'O juiz formará sua convicção pela livre apreciação da prova, inclusive elementos colhidos na fase de investigação.' A ingerência na livre convicção do juiz (artigo 155), proibindoo de levar em conta na sentença, ainda que supletivamente, elementos da fase investigatória, contraria toda 
Com base em tais argumentos houve a apresentação de propostas de emendas modificativas do texto original naquela casa legislativa. Por elas sugeria-se a consagração da orientação informalmente adotada pela jurisprudência, ou seja, da possibilidade de uso dos elementos informativos para a formação da convicção do julgador quando submetidos a contraditório diferido e concordantes com as provas produzidas em contraditório judicial. Sua utilização seria subsidiária, residual, portanto. A emenda, aprovada, reescreveu texto normativo com duas alterações significativas: "O juiz formará sua convicção pela livre apreciação da prova produzida em contraditório judicial, não podendo fundamentar sua decisão exclusivamente nos elementos informativos colhidos na investigação, ressalvadas as provas cautelares, irrepetíveis e antecipadas, e aquelas submetidas a posterior contraditório ${ }^{94,}$

a tradição do processo penal brasileiro, partindo do equivocado pressuposto de que o Magistrado, ao decidir, possa ser leviano ou inconsequente, a ponto de ser preciso vedar-lhe a prerrogativa de sopesar livremente o conjunto probatório e emprestar-lhe a devida valoração".

Cf. Deputado Flávio Dino, em 17/05/2007: "Dê-se ao art. 155 do Decreto-Lei 3.689, de 3 de outubro de 1941, constante do art. $1^{\circ}$ do projeto, a seguinte redação: “Art. 155. O juiz formará sua convicção pela livre apreciação da prova produzida em contraditório judicial, não podendo fundamentar sua decisão exclusivamente nos elementos informativos colhidos na investigação, ressalvadas as provas cautelares, irrepetiveis e antecipadas, e aquelas submetidas a posterior contraditório”. Justificativa: A presente emenda origina-se de sugestão da Associação Nacional dos Procuradores da República. A proposta original, tal como apresentada, atinge diretamente o princípio da livre convicção judicial, limitando-o seriamente. A jurisprudência atual - inclusive da Suprema Corte - é no sentido da possibilidade de o juiz utilizar dados colhidos na fase inquisitorial como elemento de convicção, desde que conjugados com outros apurados mediante o contraditório no processo criminal”. Disponíveis em: http://www.camara.gov.br/proposicoesWeb/prop_pareceres_substitutivos_votos?idProposicao=26555, acesso em 20/01/2012.

${ }^{94}$ A parte final do texto sugerida adveio de outro projeto então em andamento (aquele que versava sobre o inquérito policial - Projeto de Lei $\mathrm{n}^{\circ}$ 4209/2001). O Deputado Flávio Dino, ao sugerir emenda modificativa disse: "Dê-se ao parágrafo único do art. $7^{\circ}$ do Decreto-lei $n .^{\circ} 3.689$, de 3 de outubro de 1941 , constante do art. $1^{\circ}$ do projeto, a seguinte redação: 'Parágrafo Único. Esses elementos não poderão constituir fundamento exclusivo da sentença, ressalvadas as provas produzidas cautelarmente ou irrepetiveis, e aquelas submetidas a posterior contraditório.' Justificativa: A presente emenda origina-se de sugestão da Associação Nacional dos Procuradores da República. A proposta original, como apresentada, atinge diretamente o princípio da livre convicção judicial, limitando-o seriamente. A jurisprudência atual inclusive da Suprema Corte - é no sentido da possibilidade de o juiz utilizar dados colhidos na fase inquisitorial como elemento de convicção, desde que conjugado com outros apurados mediante o contraditório no processo criminal. Da mesma forma, elementos probatórios que podem vir aos autos na fase de inquérito, como, por exemplo, documentos bancários são passíveis de pleno e integral contraditório no momento processual. É importante, pois, ressalvar sua validade para fundamentar eventual condenação". Disponível

em: http://www.google.com.br/url?sa=t\&rct=j\&q=\&esrc=s\&source=web\&cd=1\&cts=1331204357855\&ved=0CC UQFjAA\&url=http\%3A\%2F\%2Fwww.camara.gov.br\%2FproposicoesWeb\%2Fprop_mostrarintegra\%3Bjses sionid\%3D7BECE6BFFBEF30C2F96085830D7A310F.node1\%3Fcodteor\%3D625084\%26filename\%3DEM P\%2B1\%2F2008\%2B\%253D\%253E\%2BPL\%2B4209\%2F2001\&ei=_5BYT-

jjI4TLtgf04_D9Dg\&usg=AFQjCNE9YzZuH6qvu_N5vfl3PrCPG1cxfA, acesso em 22/01/2012. 
Com a adaptação do texto legal à emenda acolhida, o Projeto de Lei ${ }^{\circ}$ 4205/01 seguiu para o Senado Federal. Nesta casa houve a proposição de nova emenda, a fim de que se restaurasse parte do texto original do artigo 155, pela supressão do termo 'exclusivamente ${ }^{, 95}$. O argumento foi o de que os elementos informativos eram produzidos à revelia do contraditório e, portanto, não poderiam ser usados na decisão criminal.

Muitos pareceres a respeito das emendas do artigo de lei foram elaborados e apresentados nas duas casas legislativas. Merece destaque o parecer dado aos 14 de março de 2008 pela Comissão de Constituição e Justiça e de Cidadania, quando acolheu a proposta de adoção do termo 'exclusivamente' no caput do artigo 155 do Código de Processo Penal, com base no entendimento do relator do Projeto de Lei na Câmara, o Deputado Flávio Dino ${ }^{96}$.

Após as discussões que permearam, por mais de seis anos, o trâmite do Projeto de Lei $\mathrm{n}^{\mathrm{o}}$ 4205/01, o Congresso Nacional aprovou, em 14 de maio de 2008, a Lei $\mathrm{n}^{\mathrm{o}}$ 11.690. A redação final do artigo 155 manteve a expressão 'exclusivamente', suprimiu a expressão 'e aquelas submetidas a posterior contraditório' (ambas inseridas no texto por emenda da Câmara dos Deputados) e alterou a expressão 'provas irrepetíveis' (advinda da redação original do anteprojeto da lei) por provas 'não repetíveis': “o juiz formará sua convicção pela livre apreciação da prova produzida em contraditório judicial, não podendo fundamentar sua decisão exclusivamente nos elementos informativos colhidos na investigação, ressalvadas as provas cautelares, não repetiveis e antecipadas".

\footnotetext{
${ }^{95}$ Emenda do Senado ao Projeto de Lei da Câmara no 37, de 2007 (PL n ${ }^{\circ} 4.205$, de 2001, na Casa de origem), de 26/12/2007: “Suprima-se a expressão 'exclusivamente' da redação proposta para o caput do art. 155 do Decreto-Lei $n^{\circ}$ 3.689, de 3 de outubro de 1941 - Código de Processo Penal, alterado pelo art. $1^{\circ}$ do Projeto”. Disponível em: http://www.camara.gov.br/proposicoesWeb/prop_pareceres_substitutivos_votos?idProposicao=26555, acesso em 19/01/2012.

${ }^{96}$ Deputado Flávio Dino, em 14/03/2008: "Parece-me, então, razoável o texto aprovado pela Câmara. Este, ao impedir que o juiz fundamente sua decisão exclusivamente nos elementos informativos colhidos na investigação, tanto resguarda o princípio da motivação, insculpido no inciso IX do artigo 93 da Constituição, como também preserva o contraditório, uma vez que a fundamentação do juiz deverá ser formulada também com base em outros elementos. Tais elementos jamais poderão ser exclusivamente os colhidos quando do inquérito, consoante consagra a atual orientação jurisprudencial dominante. O que não é razoável é simplesmente dizer-se que o contido no inquérito policial de nada vale para a formação da convicção do julgador. Por esse motivo, rejeito a Emenda $n^{o} 1$ do Senado, mantendo, assim, o texto aprovado pela Câmara para o artigo 155 do Código de Processo Penal'. Disponível em: http://www.camara.gov.br/proposicoesWeb/fichadetramitacao?idProposicao=26555, acesso em 21 de fevereiro de 2012.
} 


\subsection{Comentários sobre a norma}

O objetivo da comissão de juristas que elaborou o anteprojeto sobre provas era, de acordo com a respectiva exposição de motivos, delimitar regras de utilização do material probatório formado antes do processo criminal ganhar vida. Pretendia-se alinhar o conteúdo do artigo 155 do Código de Processo Penal à garantia do contraditório, fixada na Constituição de forma absoluta. Desta feita, os atos de prova realizados no inquérito poderiam servir à condenação (porque passíveis de contraditório, concomitante ou diferido) e os atos de investigação (mais precisamente os elementos informativos) não poderiam ser utilizados em nenhuma hipótese (haja vista as condições de sua formação).

Podemos afirmar que o objetivo não foi alcançado. Com a inclusão do advérbio 'exclusivamente' no texto normativo houve a legitimação do uso, ainda que subsidiário, de elementos informativos para a motivação da sentença. A este respeito, a leitura de diversos artigos científicos demonstra haver descontentamento por parte dos doutrinadores, que entendem que a opção do legislador esvaziou o sentido da norma.

Segundo NUCCI, "a reforma teria sido ousada se excluísse a ressalva 'exclusivamente' do artigo 155, caput do CPP. O juiz não poderia formar sua convicção nem fundamentar sua decisão com base em elementos advindos da investigação"97 (...) "apenas se tornou expresso que vinha sendo consagrado pela jurisprudência pátria há anos. O julgador jamais pôde basear sua sentença, em especial a condenatória, em elementos colhidos unicamente no inquérito policial. Não era mecanismo tolerado nem pela doutrina, nem pela jurisprudência. Porém, o juiz sempre se valeu das provas colhidas na fase investigatória, desde confirmados, posteriormente, em juízo, ou se estivessem em harmonia com as coletadas sob o crivo do contraditório"98. GRECO FILHO chegou a dizer que "melhor seria ter a lei silenciado, porque somente veio para atrapalhar o que a doutrina e a jurisprudência já adotavam como pacífico e de simples compreensão" 99 .

\footnotetext{
${ }^{97}$ In: NUCCI, Guilherme de Souza. Código de Processo Penal Comentado, 8 a edição revisada, ampliada e atualizada, $2^{\mathrm{a}}$ tiragem, São Paulo: Revista dos Tribunais, 2008, p. 341.

${ }_{98}$ In: NUCCI, Guilherme de Souza, Código de ...op. cit., p. 342.

${ }^{99}$ In: GRECO FILHO, Vicente. Manual de ...op. cit., p. 204-205.
} 
Note-se que o texto legal, tal como aprovado (autorizador, portanto, do uso não exclusivo dos elementos informativos do inquérito), seria ainda mais liberal, fosse mantida a expressão (ressalvadas as provas cautelares, irrepetíveis e antecipadas, 'e aquelas submetidas a posterior contraditóróno’') sugerida pela primeira emenda na Câmara dos Deputados.

Assim como fez com os elementos informativos, o artigo de lei reproduziu, quanto às provas cautelares, antecipadas e não repetíveis, o entendimento de que podem ser utilizadas para formar o convencimento do julgador, embora deixasse dúvidas quanto à possibilidade de seu uso ser exclusivo ou subsidiário. Sobre o tema, houve pronunciamento do Superior Tribunal de Justiça apontando a valia da interpretação de que o uso de provas cautelares, antecipadas e irrepetíveis pode ser exclusivo: "Vige em nosso ordenamento jurídico o princípio do livre convencimento motivado ou da persuasão racional, segundo o qual o magistrado pode livremente apreciar as provas, adotá-las ou recusá-las mediante convicção motivada. Contudo, há proibição expressa de fundamentação exclusiva nos elementos do inquérito, ressalvadas as provas cautelares, não repetiveis e antecipadas. Inteligência do art. 155 do Código de Processo Penal. III. Ordem concedida, nos termos do voto do Relator" ${ }^{\prime 100}$.

Especialmente no que toca às provas não repetíveis, a única alteração que se viu, desde a apresentação do anteprojeto sobre provas ao Poder Executivo até a edição da Lei ${ }^{\circ} 11.690$ pelo Congresso Nacional, foi a substituição da expressão 'irrepetíveis' por 'não repetíveis', sem que houvesse a atribuição da respectiva definição. Também não foi, diretamente, objeto de discussões mais aprofundadas.

Pensamos que o fato de o legislador não ter determinado os significados atribuíveis aos fenômenos probatórios nomeados (em especial os elementos informativos e as provas não repetíveis) gerou dificuldade de interpretação da norma e de sua aplicação prática. Com efeito, enquanto o legislador trata as provas não repetíveis como um instituto estanque dos

${ }^{100} \mathrm{HC} \mathrm{n}^{\mathrm{o}} 156.333 / \mathrm{ES}$, Relator Gilson Dipp, 05/04/2011. 
demais (elementos informativos, provas cautelares e antecipadas), doutrina e jurisprudência apontam situações em que os termos seriam convergentes:

"Há determinados atos do inquérito que se transmitem para o bojo da futura ação penal de forma definitiva, posto que impossíveis de repetição ou renovação, tais como os exames, vistorias e avaliações, a juntada de documentos, a busca, bem ou mal sucedida, a apreensão, o reconhecimento, pessoal ou fotográfico, o arresto, o sequestro de bens, ou mesmo alguma prova testemunhal que venha a se tornar irrepetivel, por eventual impossibilidade de se localizar novamente a testemunha, por exemplo" ${ }^{\text {"101 }}$.

“As provas não-repetiveis ou não renováveis são aquelas que, por sua própria natureza, tem que ser realizadas no momento de seu descobrimento, sob pena de perecimento ou impossibilidade de posterior análise. Na grande maioria dos casos, trata-se de provas técnicas que devem ser praticadas no curso do inquérito policial e cuja realização não pode ser deixada para um momento ulterior, já na fase processual"102.

"Princípio do contraditório e provas irrepetíveis. $O$ dogma derivado do princípio constitucional do contraditório, de que a força dos elementos informativos colhidos no inquérito policial se esgota com a formulação da denúncia, tem exceções inafastáveis nas provas - a começar pelo exame de corpo de delito, quando efêmero o seu objeto - que, produzidas no curso do inquérito, são irrepetíveis na instrução do processo: porque assim verdadeiramente definitivas, a produção de tais provas, no inquérito policial, há de observar com rigor as formalidades legais tendentes a emprestar-lhe maior segurança, sob pena de completa desqualificação de sua idoneidade probatória"103.

Por todo o exposto, entendemos que o conteúdo da norma autorizadora do uso de provas produzidas no inquérito não satisfez a necessidade de regulamentação da matéria. Uma leitura rápida do artigo 155 é suficiente para notar que houve a legitimação do uso de informações do inquérito, de modo não exclusivo ("não podendo fundamentar sua decisão exclusivamente nos elementos informativos colhidos na investigação"). Mas o que mais

\footnotetext{
${ }^{101}$ In: SAAD, Marta. $O$ direito de...op. cit., p.148.

102 In: LOPES JUNIOR, Aury. Sistemas de...op. cit., $1^{\text {a }}$ ed., p. 191.

${ }^{103}$ Supremo Tribunal Federal, HC 74751/RJ, Relator Ministro Sepúlveda Pertence, 04/11/1997.
} 
preocupa, em nosso sentir, é a parte final do dispositivo de lei ("ressalvadas as provas cautelares, não repetíveis e antecipadas"), que abriu margem à utilização de informações do inquérito, só que de modo exclusivo.

O conteúdo do artigo 155 do Código de Processo Penal deve ser interpretado à luz das garantias constitucionais. E para que isso seja possível, antevemos a necessidade de analisar a interatividade existente entre o fenômeno da irrepetibilidade e os demais termos (cautelares, antecipadas e elementos informativos) aos quais o artigo de lei faz referência.

\section{Uma proposta de sistematização terminológica sobre a irrepetibilidade das provas}

Entendemos que pelo estudo da irrepetibilidade probatória perquire-se, em verdade, a compreensão das hipóteses de utilização do material probatório das investigações na formação do convencimento do julgador. Para tanto há a necessidade de uma análise amplificada, não limitada a identificar provas irrepetíveis, mas que busque identificar, no conjunto de provas (repetíveis e não repetíveis), aquelas que podem ser usadas na motivação da sentença criminal.

A sistematização que buscaremos apresentar combina hipóteses de provas repetíveis e provas irrepetíveis, suscitadas pela doutrina e legislação italianas. Com relação às provas repetíveis, cabe ressaltar que não encontramos na bibliografia pesquisada a sugestão de uma classificação aplicável ao fenômeno. Por isso, e em razão de sua delimitação ser importante ao nosso estudo (especialmente para tornar mais clara a análise das regras italianas relacionadas à aceitação de provas produzidas em fases anteriores do processo), sugeriremos uma classificação própria (provas repetíveis perfeitas e imperfeitas).

Como mencionamos anteriormente, a possibilidade de produção de determinada prova na audiência de julgamento depende da subsistência das pessoas ou objetos que trarão elementos de prova para o processo. Desde a obtenção de um elemento informativo, na etapa do inquérito, até a audiência de julgamento, a fonte de prova da qual ele emanou pode: (i) conservar-se, sendo, portanto, repetível; ou (ii) extinguir-se ou alterar-se (a ponto 
de tornar-se imprestável aos fins do processo), sendo, portanto, irrepetível. Vejamos as hipóteses separadamente.

\subsection{A prova repetível e sua classificação (prova repetível perfeita e imperfeita)}

Pode-se dizer repetível a prova cuja fonte mantém-se íntegra, vale dizer, tal qual o era à época do crime, até a audiência de julgamento.

Tomemos como exemplo a prova testemunhal, que é, a princípio, uma prova repetível. Se a testemunha visual de um crime for submetida a exame testemunhal no inquérito haverá a produção de um elemento informativo (consubstanciado em seu testemunho, tomado pela autoridade policial). Naturalmente, será intimada a comparecer para depor em juízo, a fim de trazer para o processo um elemento de prova (no caso, o testemunho tomado perante a autoridade judicial, com respeito ao procedimento previsto em lei). Despontam, aqui, as seguintes possibilidades:

1. A testemunha comparece à audiência judicial, presta depoimento e submetese ao exame cruzado com as partes (acusação e defesa). Neste caso, a prova, a princípio repetível, se perfez. Denominaremos esta hipótese de prova repetível perfeita.

2. A testemunha, que poderia comparecer à audiência de julgamento, decide não fazê-lo. Ou, apresentando-se, opta por ficar em silêncio. Ou, submetendo-se ao depoimento, nega-se ao exame cruzado. São situações em que a prova, a princípio repetível, não se perfez por razão atribuível à vontade humana - quer da testemunha, que consciente e voluntariamente subtrai-se aos respectivos deveres processuais, quer de terceiro, que lança mão de ameaça, violência ou suborno para influenciá-la a eximir-se de suas obrigações. Denominaremos esta hipótese de prova repetível imperfeita.

\subsection{A prova de irrepetibilidade natural}


Refere-se aqui à fonte de prova que se modifica ou extingue com o passar do tempo, perdendo-se antes da audiência de julgamento, por circunstância possível de se antever ao tempo da fase inquisitiva da persecução penal. Recebem da doutrina brasileira a denominação de provas de "irrepetibilidade natural" 104 e da italiana de atos "nato irripetibile ${ }^{105}$.

Em nosso sentir, a irrepetibilidade natural decorre da transitoriedade associada à fonte de prova. Pensemos, por exemplo, no alimento envenenado que deva ser periciado, nos restos mortais submetidos à autópsia, na lesão corporal objeto do corpo de delito, na vítima adoecida que deponha no leito de morte. São casos em que a natureza (notadamente transitória) da fonte de prova permite supor que ela não perdurará até a audiência de julgamento. Em razão disso, a pessoa ou objeto de natureza mutável deve ser submetido à produção antecipada de prova, a fim de que se resguarde o elemento de prova que se perderia não fosse imediatamente produzido.

Podemos ainda citar as fontes de prova cujas circunstâncias que a rodeiam sejam transitórias e, por isso, lhes impinjam um caráter de urgência. Assim, por exemplo, a busca motivada por denúncia anônima, realizada na casa de pessoa suspeita de ocultar a vítima sequestrada, ou a apreensão do computador de pessoa suspeita de nele arquivar material relacionado à pornografia infantil.

Nesses casos, embora as fontes de prova (na primeira situação o próprio ofendido e, na segunda, os arquivos ilícitos do computador) sejam, a princípio, duráveis, a situação que as cerca é transitória. A urgência, assim, legitima a realização imediata do ato, mesmo que sem a participação do suspeito ou seu defensor, para que se resguarde a própria fonte de prova.

Pertencem a este grupo as provas cautelares stricto sensu, vale dizer, os meios de investigação utilizados pela polícia na busca por fontes de prova, que dependem de

\footnotetext{
${ }^{104}$ Cf. FERNANDES, Antonio Scarance. Processo Penal ...op.cit., $6^{\text {a }}$ ed., p. 66.

${ }^{105}$ Cf. DI MARTINO, Corrada; PROCACCIANTI, Teresa. La prova testimoniale nel processo penale. $2^{\mathrm{a}}$ edizione, Padova: Cedam, 2010, p. 367.
} 
autorização judicial e devem ser submetidos a controle de legalidade e ao contraditório, postergados.

\subsection{A prova de irrepetibilidade superveniente}

Retrata-se a situação da fonte da prova, a princípio repetível, que se modifica ou extingue antes do processo criminal tomar vida, por circunstância imprevisível, ou seja, impossível de se antever ao tempo da produção da prova na fase inquisitiva da persecução penal. São denominadas pela doutrina provas de "irrepetibilidade resultante de fato posterior" "106 ou de "irripetibilità sopravvenuta" 107.

Como dissemos, as provas de irrepetibilidade superveniente são, a princípio, repetíveis. Mas distinguem-se das provas repetíveis imperfeitas porque, diferentemente destas, são situações independentes da vontade humana que impedem a produção da prova em juízo. Pensemos, novamente, no exemplo da testemunha.

A testemunha visual de um crime, submetida a exame testemunhal no inquérito, será intimada a comparecer para depor em juízo, a fim de trazer para o processo um elemento de prova. Despontam, aqui, as seguintes possibilidades:

1. A testemunha, até então saudável, falece inesperadamente (como em um acidente automobilístico, por exemplo);

2. A testemunha, até então saudável, é subitamente acometida por doença incapacitante, como amnésia ou doença mental degenerativa que a impossibilite de depor no julgamento e cuja cura seja imprevisível; ou

3. A testemunha, até então participativa no processo, desaparece, sendo impossível sua localização.

\footnotetext{
${ }^{106}$ Cf. FERNANDES, Antonio Scarance. Processo Penal ...op.cit., 6 a ed., p. 66.

${ }^{107}$ Cf. DI MARTINO, Corrada; PROCACCIANTI, Teresa. La prova ...op. cit., p. 366.
} 
Em resumo, a prova de irrepetibilidade superveniente circunscreve-se à impossibilidade de produção de prova oral no julgamento, em razão de fatos (morte, doença ou desaparecimento) inesperados sobre os quais o declarante não tem controle.

Em linhas gerais, a sistematização proposta pode ser assim esquematizada:

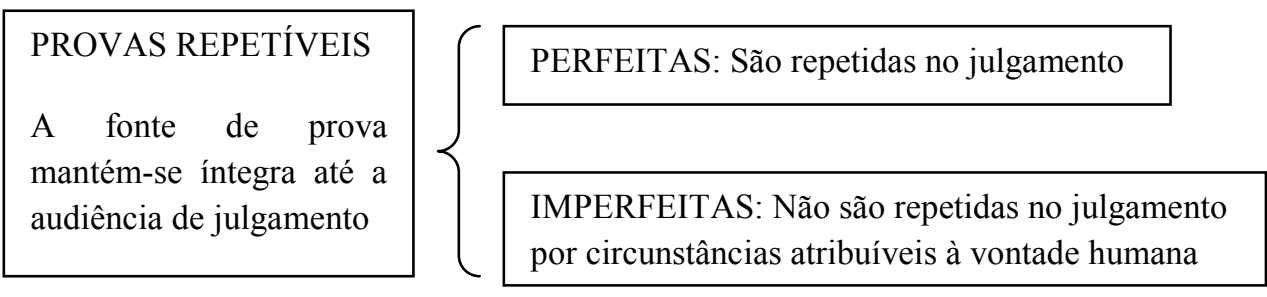

\section{PROVAS IRREPETÍVEIS}

A fonte de prova modificase ou extingue-se antes da audiência de julgamento

NATURAIS: a fonte de prova não subsiste até o julgamento em razão de sua natureza transitória

SUPERVENIENTES: a fonte de prova não subsite até o julgamento por circunstâncias imprevisíveis e não atribuíveis à vontade humana

É possível perceber que a expressão 'provas não repetíveis' do artigo 155 do Código de Processo Penal possui áreas de convergência com os demais fenômenos probatórios descritos no mesmo artigo de lei: as provas repetíveis (perfeitas e imperfeitas) e as provas de irrepetibilidade superveniente remetem à discussão sobre a possibilidade de utilização, na formação do convencimento do julgador, de elementos informativos do inquérito; as provas naturalmente irrepetíveis o fazem com relação às provas cautelares (em sentido estrito) e às antecipadas.

Buscaremos analisar, no próximo capítulo, as provas ora apresentadas (repetíveis e não repetíveis), com respaldo na experiência italiana. 


\section{CAPÍTULO III. PROVAS REPETÍVEIS E NÃO REPETÍVEIS: UMA ANÁLISE À LUZ DAS REGRAS DO DIREITO ITALIANO}

\section{As provas de fases anteriores do processo: aceitabilidade e disciplina normativa}

Com vistas a dar termo final aos resquícios do sistema inquisitivo, instituído na Itália na conjuntura do fascismo ${ }^{108}$, o legislador de 1989 contemplou o sistema acusatório (idealizado na Constituição Italiana de 1948) no Código de Processo Penal, em sua forma mais pura.

Antes mesmo de sua aprovação, o diploma processual penal foi criticado por parte da doutrina, que entendia que as previsões nele contidas deveriam ser inseridas gradualmente no ordenamento jurídico, a fim de que fosse possível identificar, na prática, sua adequação aos anseios sociais e necessidades de combate à criminalidade. Mesmo a par das críticas, o poder executivo do país optou por promulgar o codex, do modo como concebido: “com base em estudos teóricos, sem que os novos institutos tivessem sido, na prática, aplicados" ${ }^{\prime 109}$.

Em razão disso, desde seus primórdios, o Código de Processo Penal Italiano de 1989 tem sido objeto de constantes alterações, muitas delas efetuadas pelo legislador em razão de interpretações jurisprudenciais da Corte Constitucional da Itália - órgão de cúpula do poder judiciário que exerce o controle concentrado de constitucionalidade das leis da República Italiana.

Ao inserir o princípio da oralidade no Código de Processo Penal de 1989, o legislador italiano o previu, originalmente, de forma absoluta ${ }^{110}$. Assim, as declarações de partes

\footnotetext{
${ }^{108}$ Por meio da implementação do Código Rocco de 1931.

${ }^{109}$ In: TONINI, Paolo. A prova ..., op. cit., p.18.

110 Dito de outro modo, somente era aceita como prova aquela produzida perante autoridade judicial, de forma oral.
} 
privadas $^{111}$ e testemunhas, feitos perante o órgão acusador ou a polícia judiciária na fase das investigações preliminares não podiam compor as provas que formavam o convencimento do julgador. A orientação, como outras, foi alvo de censura, pois impossibilitava a utilização das declarações precedentes, mesmo em casos de gravidade excepcional, em que ela se fazia imprescindível à efetivação da justiça.

Os casos que suscitaram crítica dos juristas relacionavam-se a pratica de crimes graves e de difícil comprovação, como a criminalidade mafiosa organizada. O princípio da oralidade, rigidamente adotado, impedia, por exemplo, a leitura de declaração feita em fase anterior do processo por testemunha e 'réu acusador' (vale dizer, réu que declara em desfavor de corréu), que em razão de terem sido ameaçados de morte, negavam-se a depor na audiência de debates e julgamento. Também impedia o uso de declarações feitas na fase das investigações por testemunhas e réus acusadores assassinados pela máfia antes que pudessem depor em juízo, dentre outros.

Foi em razão da necessidade de garantir o combate à criminalidade organizada que a Corte Constitucional italiana mitigou o princípio da oralidade, estabelecendo outro diametralmente oposto, da "não dispersão da prova colhida antes da fase de debates" "112. O fez por meio da prolação de duas sentenças (254 e 255 de 1992) que validaram a utilização de declarações, prestadas na fase das investigações, por testemunhas e por réus acusadores.

A orientação jurisprudencial foi convertida em lei (Lei $\left.\mathrm{n}^{\mathrm{o}} 356 / 1992\right)$, que previa a possibilidade de leitura de provas produzidas em fases anteriores do processo, dentre as quais aquelas que não pudessem ser repetidas por causas supervenientes.

\footnotetext{
${ }^{111}$ Segundo o artigo 503 do Código de Processo Penal italiano são partes privadas a parte civil (vítima ou seu procurador), o responsável civil (acusado ou, em determinados casos, seu responsável legal), a pessoa civilmente obrigada à pena pecuniária (acusado ou pessoa - física ou jurídica - a quem esteja vinculado) e o imputado (pessoa denunciada, processada em qualquer das instâncias e ritos do processo criminal italiano).

${ }^{112}$ Trata-se de garantia inexistente no direito processual penal brasileiro, mas utilizada no direito italiano para legitimar o uso de provas não repetíveis nos julgamentos criminais daquele país. O princípio da não dispersão das provas colhidas antes da fase de debates nasceu como uma exceção (constitucionalmente consagrada) ao princípio geral do Contraditório na produção da prova.
} 
Posteriormente, editou-se uma nova norma (Lei $n^{0}$ 267/1997), que buscou melhor regulamentar as situações de aceitabilidade das declarações precedentes de réu acusador, a fim de compatibilizá-las com o contraditório (até então garantido de modo absoluto na Constituição). A norma dispunha que as declarações por ele prestadas nas investigações somente poderiam ser utilizadas se produzidas em contraditório e repetidas no julgamento - exceto quando se tornassem irrepetíveis por causa superveniente. A fim de complementar a Lei n 267 , foi editada, em 1998, a Lei n 361, que equiparou a situação do réu acusador à da testemunha, permitindo, assim, que suas declarações precedentes também fossem utilizadas quando permanecesse silente no julgamento.

Mesmo após a criação de normas que afirmavam expressamente a necessidade das declarações precedentes serem formadas em contraditório para que pudessem ser utilizadas no julgamento, a Corte Constitucional continuou a interpretá-las no sentido de que poderiam ser aceitas declarações não produzidas em contraditório na fase das investigações. Segundo TONINI a interpretação distorcida das normas "suscitou a reação do Parlamento italiano, que acusou a Corte Constitucional de ter legislado sobre matéria cuja competência é reservada ao Poder legislativo e, ainda, de tê-lo feito de forma errônea, ou seja, de modo dissonante dos principios constitucionais" ${ }^{113}$.

Houve forte reação do poder legislativo, que elaborou projeto de emenda constitucional para assegurar, de modo eficiente, os princípios decorrentes do justo processo, contidos na Convenção Europeia de Direitos do Homem. O objetivo primordial do projeto era o de "afirmar o princípio do contraditório, fazendo-o atuar na formação da prova" ".114. Ele seria inserido como princípio absoluto e indeclinável no artigo 111 da Constituição, juntamente com as garantias da reserva de lei em matéria processual, paridade de armas, imparcialidade do julgador e razoável duração dos processos.

O texto foi aprovado, todavia, com modificações. Firmou-se a regra do contraditório na formação da prova, mas sobre ela erigiram-se três exceções. O artigo 111 da Constituição italiana passou a ser escrito (como ainda o é) da seguinte forma:

\footnotetext{
${ }^{113}$ In: TONINI, Paolo. A prova ..., op. cit., p. 20-21.

${ }^{114}$ In: TONINI, Paolo. A prova ..., op. cit., p. 21.
} 
“A jurisdição será exercida mediante o justo processo, regulado pela lei. 1. O processo se desenvolverá mediante a confrontação entre as partes, em condições de igualdade, perante um juiz imparcial e com a duração razoável garantida pela lei. 2. Nos processos criminais a lei garantirá que a pessoa acusada de um delito: seja informada, o quanto antes e reservadamente, sobre a natureza e os motivos da acusação contra si existente; que disponha de tempo hábil e das condições necessárias para preparar sua defesa; que tenha a faculdade, ante o juiz, de interrogar ou de fazer interrogar aqueles que contra ela deporem; obter a convocação e o interrogatório de pessoas para deporem em sua defesa, nas mesmas condições que a acusação, bem como de utilizar qualquer outro meio de prova a seu favor; e ter a assistência de um intérprete caso não compreenda ou fale a língua utilizada no processo. 3. O processo penal regula-se pelo princípio do contraditório na produção das provas. 4. Não se poderá fundamentar a culpabilidade do acusado em declarações feitas por pessoas que, por livre escolha, não tenham se submetido ao confronto com o acusado e seu defensor. 5. A lei regulamentará os casos excepcionais em que a produção da prova não é realizada sob o crivo do contraditório por consenso do imputado, por demonstrada impossibilidade de caráter objetivo ou por efeito de uma conduta manifestamente ilícita" (tradução livre).

Assim, após anos de discussões travadas entre o poder legislativo e a Corte Constitucional italiana, houve alteração no texto da Constituição que acomodou a garantia do contraditório na formação da prova, que somente pode ser afastada quando existente uma das três referidas hipóteses (consenso do imputado, conduta manifestamente ilícita e impossibilidade de caráter objetivo) a ela relacionadas, todas legitimadoras da utilização de provas produzidas antes da audiência de julgamento. Sua regulamentação, segundo a própria Constituição, ficou a cargo do legislador infraconstitucional, que a fez pela edição de algumas leis, dentre as quais merece destaque a Lei $n^{0}$ 63/2001, que ficou conhecida como a lei do justo processo.

A Lei $n^{\circ} 63 / 2001$ buscou delimitar as hipóteses em que seria possível o aproveitamento das declarações de réu acusador e de testemunha, proferidas antes do juízo oral. Dentre suas disposições fez inserir no Código de Processo Penal norma (artigo 197-bis) segundo a qual os réus acusadores, para os quais a sentença houvesse transitado em julgado, deveriam ter 
tratamento de testemunha ${ }^{115}$ (ou seja, poderiam cometer crime de falso testemunho) quando depusessem sobre fatos relacionados ao comparsa que está em julgamento.

Buscaremos, nos próximos dois itens deste Capítulo, examinar, à luz do regramento italiano (previsto na Constituição e no Código de Processo Penal), as peculiaridades das provas repetíveis e irrepetíveis e as questões controversas a elas associadas. Com isso, teremos condições de efetuar uma análise sobre a viabilidade de aplicação da regulamentação italiana no processo penal brasileiro, à luz do que estabelece nossa própria Constituição.

\section{2. $O$ estudo das provas repetíveis}

\subsection{Aspectos relevantes e problemática relacionada à prova repetível perfeita}

No Brasil é comum a utilização de elemento informativo do inquérito para a formação do convencimento do julgador, mesmo nos casos em que a prova é repetida em juízo (ou, segundo nossa terminologia, mesmo quando se está diante de prova repetível perfeita). A prática é acolhida pelo artigo 155 do Código de Processo Penal.

Em termos práticos, tomemos como exemplo uma testemunha, que tendo prestado informações na fase do inquérito, volte a fazê-lo na audiência de julgamento. Seu testemunho, produzido oralmente na audiência, pode estar alinhado ao testemunho por ela fornecido no inquérito. Nesta hipótese, o uso do elemento informativo não macula o convencimento do julgador, apenas reforça-o, motivo pelo qual sua utilização é aceita sem grandes questionamentos.

Uma segunda hipótese é de que o testemunho produzido oralmente na audiência oponha-se ao testemunho tomado no inquérito, situação em que o elemento informativo acabará por ser utilizado para confrontar a prova judicial. Neste caso, se for concordante com outras

115 "É inegável que a palavra do acusado, com relação aos demais, é testemunho. Testemunho e, consequentemente, meio de prova" In: GRINOVER, Ada Pellegrini. O processo em evolução, Rio de Janeiro: Forense Universitária, 1996, p. 352. 
provas (produzidas em contraditório), pode ser utilizado como prova para a condenação, haja vista seu caráter subsidiário, e não exclusivo, na formação do convencimento do julgador.

Pela segunda hipótese apontada é possível perceber que no processo penal brasileiro o uso de elementos informativos do inquérito para o cotejo da prova judicial pode influir na decisão do julgador. Mas, mais que isso, as informações do inquérito adquirem valor probante e, mesmo que subsidiariamente utilizadas, interferem no resultado final da causa. Sobre o tema, ZILLI explica que o artigo 155 do Código de Processo Penal autoriza o juiz “a buscar naqueles elementos o reforço para certas provas produzidas em contraditório, confirmando assim a veracidade de uma das teses. Mais lógico seria que o conflito resultante das provas divergentes, não superável pela possibilidade de obtenção de novas provas, levasse à absolvição do acusado e não à invocação de elementos colhidos unilateralmente" 116 .

$\mathrm{Na}$ Itália, embora as declarações prestadas nas fases anteriores do processo também possam ser utilizadas para o fim de confrontar os testemunhos tomados oralmente na audiência, não podem servir ao convencimento do julgador. Trata-se de hipótese denominada leitura contestatória. Passemos à sua análise.

Reza o inciso $3^{\circ}$ do artigo 111 da carta maior italiana, que "o processo penal regula-se pelo princípio do contraditório na produção das provas". A regra, portanto, é a de que as provas sejam produzidas na audiência de julgamento, em contraditório concomitante.

A fim de assegurar o contraditório de forma eficiente no julgamento, previu o legislador italiano, no Código de Processo Penal, a possibilidade da leitura de depoimentos prestados em fases anteriores do processo, com a finalidade de possibilitar ao juiz e às partes a contestação da veracidade das declarações prestadas oralmente por réus, réus acusadores, vítimas e testemunhas que estejam depondo no juízo oral, a fim de firmar sua credibilidade.

116 In: ZILLI, Marcos. O pomar e as pragas. In: Boletim do IBCCRIM, ano 16, n. 188, julho 2008, p. 02. 
Segundo TRAMONTANO, a garantia à correta aferição do depoimento propicia um contraditório eficiente entre as partes, fazendo atuar o princípio do justo processo ${ }^{117}$.

Note-se que a contestação probatória é feita com o fim de firmar a credibilidade do depoente, apenas. Em decorrência disso, não há permissão para a utilização da declaração precedente como prova dos fatos, em detrimento à versão judicial: “a contestação serve no máximo para retirar o valor da declaração da fase de debates, mas não é útil para formar a prova da existência do fato narrado" ${ }^{118}$. Daí dizer-se que esta modalidade de leitura (de prova produzida em fases anteriores do processo) não fere o princípio do contraditório na formação da prova, mas, ao contrário, reforça-o.

São hipóteses de leitura para contestação probatória, as dispostas no artigo 499, inciso 6, artigo 500, incisos 1 e 2, e artigo 503, incisos 3 e 4, todos do Código de Processo Penal italiano. Tais disposições foram introduzidas no ordenamento pela Lei $n^{0} 63 / 2001$, com o escopo de fornecer ao juiz presidente os instrumentos necessários para que supervisione e assegure o correto desenvolvimento do exame testemunhal.

O juiz presidente, na qualidade de garante da legalidade da instrução probatória, está obrigado a salvaguardar os direitos do acusado, em especial, assegurando-lhe que o confronto dialético ocorra com base em perguntas pertinentes e respostas verdadeiras.

A contestação probatória pode ser feita com base nas declarações precedentes (mesmo que advindas dos autos da defesa ou do Ministério Público), prestadas pela mesma pessoa, e deve circunscrever-se aos fatos e circunstâncias sobre os quais ela tenha se pronunciado anteriormente. Segundo TONINI, a contestação também é possível nos casos em que testemunha ou parte privada tenha permanecido em silêncio na audiência, ao ser inquirida sobre o conteúdo das declarações precedentes. Argumenta o autor que, na aludida hipótese, "a contestação tem como função incitar o declarante a responder e a submeter-se ao exame cruzado",119.

117 Cf. TRAMONTANO, Luigi. Codice di procedura penale spiegato, $9^{\mathrm{a}}$ edizione, Piacenza: La tribuna, 2011, p. 1146.

${ }_{118}$ Cf. TONINI, Paolo. A prova ..., op. cit., p. 227.

${ }^{119}$ In: TONINI, Paolo. A prova ..., op. cit., p. 226. 
A única possibilidade admitida pela lei italiana para a utilização de leitura contestatória como prova (apta, portanto, a formar o convencimento do julgador) subsume-se aos casos em que haja "consenso do imputado".

A possibilidade de excepcionar-se o contraditório por consenso do imputado é uma das três exceções ao contraditório previstas na Constituição italiana (artigo 111, inciso $5^{\circ}$ ). Por meio dela, consentindo o acusado, as declarações próprias ou de testemunhas tomadas perante o Ministério Público na etapa das investigações, poderão ser lidas na audiência de julgamento (sejam elas provas repetíveis ou irrepetíveis).

Debate a doutrina italiana sobre a possibilidade de aceitação da norma, por haver entendimento de que no processo penal, diferentemente do que ocorre no processo civil, o contraditório é irrenunciável. Todavia, tem-se aceito a leitura das declarações precedentes, nesta hipótese, quando tal não interfira na correta percepção dos fatos pelo órgão judicial.

Sobre o assunto, DI MARTINO e PROCACCIANTI, citando Ferrua, esclarecem: “infatti, uma corretta interpretazione della previssione del legislatore costituzionale, dovrebbe andare nel senso di attribuire rilevanza alla rinuncia al contradditorio solo in quanto si possa ragionevolmente supporre che la scelta non si rifletta negativamente sulla giustizia della decisione, almeno sotto in profilo della ricostruzione dei fatti ${ }^{, 120}$.

Note-se que em razão de o acusado não ter, em princípio, a capacidade de compreender e avaliar os prejuízos que podem advir de sua permissão (para que se utilize prova produzida à revelia do contraditório), tem-se atribuído tal tarefa à defesa técnica.

Mais que isso, em nome da necessidade de igualdade entre defesa e acusação, a interpretação que o legislador ordinário deu à norma constitucional (ao editar a Lei $\mathrm{n}^{\mathrm{o}}$ 274/2000) foi a de que deve haver consenso entre as partes. Deste modo, a exceção relativa

${ }^{120}$ In: DI MARTINO, Corrada; PROCACCIANTI, Teresa. La prova...op. cit., p. 343-344. 
ao consenso do imputado é tratada no Código de Processo Penal por meio de expressões mais amplas, como $o$ "consenso das partes" 121.

\subsection{Aspectos relevantes e problemática relacionada à prova repetível imperfeita}

No Brasil, conforme mencionado no Capítulo II, os elementos informativos da fase inquisitiva da persecução penal ingressam no processo, juntamente com os autos do inquérito, depois de finalizada a investigação, por ocasião do recebimento da denúncia.

Assim, mesmo que a testemunha, intimada para depor em juízo, não compareça à audiência, ou, comparecendo, não deponha, minta ou negue-se ao exame cruzado, pode o juiz ter acesso ao seu anterior depoimento (colhido no inquérito), utilizando-o subsidiariamente para formar seu convencimento.

Na Itália também é possível a utilização de prova repetível imperfeita para formar o convencimento do julgador, por tratar-se de uma das três exceções ao contraditório previstas no inciso $5^{\circ}$ do artigo 111 da Constituição italiana (subsumida à hipótese de “conduta manifestamente ilícita”). Mas há regras específicas e bem delimitadas para sua aceitação.

Pela normativa italiana, será manifestamente ilícita a conduta do acusado, testemunha ou réu acusador que tenha por objetivo, direto ou indireto, a frustração do contraditório na audiência de julgamento. Diz-se, nestes casos, que a impossibilidade do contraditório tem natureza subjetiva.

A impossibilidade de natureza subjetiva pode ser voluntária ou atribuível à parte. Em sentido amplo, CESARI relaciona a impossibilità volontaria e a impossibilità attribuibile

${ }^{121}$ A exemplo da expressão "accordo delle parti" utilizada no artigo 500, inciso 7 do Código de Processo Penal italiano. No mesmo sentido, artigo 431, inciso 2, artigo 493, inciso 3, artigo 513, inciso 2, artigo 555, inciso 4, dentre outros do mesmo diploma legal. 
alla parte ao "comportamento del dichiarante che decida per libera scelta di sottrarsi al confronto dialettico" ${ }^{\prime 22}$.

A Corte Constitucional, por meio da sentença $n^{0}$ 453/2002, esclareceu que à disposição constitucional associa-se "una lettura lata, tale da abbracciare - oltre alle condotte illecite poste in essere'sul'dichiarante (quali la violenza, la minaccia o la subornazione) - anche quelle realizzate dal'dichiarante stesso in occasione dell'esame in conttradditorio (quale, in primis, la falsa testimonianza, anche ne la forma della reticenza)".

As testemunhas têm o dever de comparecer à audiência judicial para depor, quando intimadas. E em audiência, têm o dever de responder às perguntas que lhe são formuladas, participando do exame cruzado ${ }^{123}$. Note-se que os réus de procedimentos conexos, para os quais tenha havido trânsito em julgado da sentença criminal, podem ser convocados a depor na qualidade de testemunhas, assumindo, assim, a qualidade de réus acusadores e as obrigações a elas concernentes ${ }^{124}$.

Ao negarem o cumprimento de suas obrigações, por vontade própria e de modo consciente (impossibilidade de natureza subjetiva e voluntária), os declarantes estarão agindo em prejuízo à garantia do contraditório. Suas atitudes, assim, autorizam a leitura das declarações prestadas nas fases anteriores do processo ${ }^{125}$.

\footnotetext{
${ }^{122}$ In: CESARI, C. Giusto processo, contraddittorio ed irrepetibilità degli atti d'indagine. In: Rivista italiana di diritto processuale penale, 2001, $\mathrm{n}^{\mathrm{o}} 75$, p. 69 e ss.

${ }^{123}$ Cf. artigo 198, inciso 1 do Código de Processo Penal italiano.

${ }^{124}$ Cf. artigo 197-bis, incisos 1 e 2 do Código de Processo Penal italiano. Ressalte-se que se o réu, no respectivo julgamento, optar por falar em prejuízo de corréu (do mesmo processo ou de processo conexo, atuando, desta forma, como réu acusador), para quem não houve o trânsito em julgado da sentença, será avisado pelo juiz de que receberá o tratamento de testemunha. Neste caso, se não depor verdadeiramente sobre os fatos, cometerá crime de falso testemunho (ilícito, portanto), que autorizará a leitura de seu interrogatório anterior. A leitura, todavia, é autorizada somente quanto à parte em que revelar a culpabilidade do corréu, em razão do direito a não autoincriminação. "Prima dell'inizio dell'interrogatio, la persona che vi è sottoposta deve, fra l'altro, essere avvertita che, se renderà dichiarazioni su fatti concernenti la responsabilità di altri, assumerà, in ordine a tali fatti, la qualifica di testimone e il correlativo obbligo di rispondere secondo verità alle domenade che le vengono rivolte". In: DI MARTINO, Corrada; PROCACCIANTI, Teresa. La prova...op. cit., p. 60.

${ }^{125}$ Cf. artigo 500, inciso 3 e artigo 513, incisos 1 e 2 (parte final) do Código de Processo Penal italiano.
} 
Mas ressalte-se: nesse caso, as declarações anteriores poderão ser utilizadas somente em favor daquele acusado ${ }^{126}$ a quem o declarante negou submeter-se ao exame cruzado, nunca em seu desfavor (com exceção do caso em que a parte prejudicada concorde com a leitura $)^{127}$. A inutilizabilidade do depoimento anterior é, desta forma, subjetivamente orientada, como explicam DI MARTINO e PROCACCIANTI: "si introduce un'ipotesi de inutilizzabilità 'soggettivamente orientata' rectius 'relativa' (...) cioè, la deposizione sara utilizzabile dal giudice per motivare le sue conclusioni, salvo a non poter utilmente sopportare le decisioni relative al soggetto provato del diritto ad interrogare o controinterrogare, a meno che l'interessato vi consenta (si introduce un'altra ipotesi di prova negoziata) ${ }^{, 128}$.

Para TONINI "o legislador pretendeu remediar um fenômeno degenerativo que ocorria na pratica. Vale dizer, muitas vezes, o declarante citado e inquirido por uma parte recusava a submeter-se ao contra-exame requerido pelas demais partes. Tratava-se de situação extremamente delicada para a parte vitima da recusa da testemunha"129.

Também será autorizada a leitura das declarações anteriores de testemunhas que se negarem a depor no juízo oral ou, depondo, alterarem a versão apresentada, em razão de terem sido expostas à violência, ameaça ou corrupção, por conduta ilícita atribuível ao acusado (impossibilidade de natureza subjetiva, atribuível à parte). Neste caso, a prova pode ser valorada em prejuízo do acusado, mesmo que sem a concordância das partes.

Tal disposição foi inserida no artigo 500, incisos 4 e 5 do Código de Processo Penal italiano por meio da Lei $n^{o}$ 63/2001. Representa um dos pontos mais delicados do modelo processual penal vigente na Itália e é objeto de crítica pela doutrina.

Segundo TRAMONTANO, "a rigore, non dovrebbero entrare a far parte del patrimonio conoscitivo legittimamente utilizzabile ain fini della statuizione finale, si sono incentrati $i$ diversi e sucessivi interventi del legislatore e della Corte Constituzionale che, negli anni,

\footnotetext{
${ }^{126} \mathrm{Cf}$. TONINI, os réus poderão utilizar as declarações precedentes para comprovarem a inocência (TONINI, Paolo. A prova ..., op. cit., p. 29-31).

${ }_{127}$ Cf. artigo 500, inciso 3 e artigo 526, inciso 1bis, ambos do Código de Processo Penal italiano.

${ }^{128}$ In: DI MARTINO, Corrada; PROCACCIANTI, Teresa. La prova...op. cit., p. 330.

${ }^{129}$ In: TONINI, Paolo. A prova ..., op. cit., p. 229-230.
} 
hanno conferito caratteri sempre nuovi all'istituto de quo, a volte conformandolo ai canoni tipici del sistema accusatorio (circoscrivendo, di conseguenza, le sue potenzialità dimostrative), altre volte piegandolo ad esigenze di non dispersione del materiale istruttorio precedentemente raccolto che però, allo stato attuale, devono ritenersi definitivamente superate dalla riconosciuta centralità del principio del contradittorio nella formazione della prova (...) nella situazione da ultimo descritta l'atto di indagine entra direttamente nel patrimonio conoscitivo su cui dovrà formarsi il libero convincimento del giudice, potendo ligittimamente fondare la deliberazione giudiziale" ${ }^{\text {130. }}$.

Com base nesta regra a jurisprudência italiana reconheceu, por exemplo, a prevalência do reconhecimento fotográfico positivo realizado perante a polícia judiciária em detrimento do reconhecimento pessoal negativo efetuado em juízo ${ }^{131}$. Note-se que as declarações precedentes de testemunha exposta à violência, ameaça ou corrupção podem ser lidas na íntegra (e não somente com relação aos fatos declarados em audiência, como ocorre no caso da contestação probatória para firmar a credibilidade da testemunha) e utilizadas como prova dos fatos narrados (mas apenas com relação àqueles que participaram da produção da referida prova) ${ }^{132}$.

\section{O estudo das provas não repetíveis}

\subsection{Considerações gerais}

As provas não repetíveis, conforme dissemos no Capítulo II, são aquelas cujas fontes (pessoas ou objetos) não puderem ser submetidas a exame na audiência de julgamento, em razão de alteração significativa das características que lhe são peculiares, ou de sua extinção.

\footnotetext{
${ }^{130}$ In: TRAMONTANO, Luigi. Codice di ...op. cit., p. 1149.

131 “Qualora sussista discrasia tra l'esito della ricognizione fotografica eseguita dinanzi alla polizia giudiziaria e quello della ricognizione personale esperita nel corso del dibattimento, la possibilità di ritenere prevalente il primo sul secondo è subordinata alla ricorrenza delle condizioni indicate nell'art. 500, comma 4, c.p.p., e cioè alla sussistenza di elementi concreti per ritenere che il testimone sia stato sottoposto a violenza, minaccia, offerta o promessa di danaro o di altra utilità affinchè non deponga ovvero deponga il falso" (14855/03, rv. 224371).

${ }^{132}$ Cf. TONINI, Paolo. A prova ..., op. cit., p. 228-229.
} 
Na Itália, a autorização para o uso de provas não repetíveis repousa na denominada "impossibilidade de caráter objetivo", exceção ao contraditório estabelecida no artigo 111, inciso $5^{\circ}$ da Constituição italiana (juntamente com as exceções relativas ao consenso do imputado e à conduta manifestamente ilícita, abordadas no item anterior do trabalho).

O conceito de impossibilidade de caráter objetivo contrapõe-se ao de impossibilidade de caráter subjetivo, anteriormente apontado ${ }^{133}$. CESARI explica que a impossibilidade de caráter objetivo está relacionada àquela que "não deriva de uma escolha voluntária da fonte de prova" ${ }^{\text {134 }}$. Sob esta ótica, UBERTIS enfatiza que a impossibilidade de caráter objetivo não compreende, por exemplo, o exercício da faculdade legitimamente assegurada a parentes próximos do acusado, de absterem-se de depor ${ }^{135}$ (cf. artigo 199 do Código de Processo Penal italiano).

À mesma conclusão chegou TONINI, ao dizer que "o termo 'objetiva', utilizado na norma em questão, parece fazer alusão àquelas causas independentes da vontade alheia, similares a situações de força maior" 136.

Esse também foi o sentir da Corte Constitucional italiana, ao manifestar-se sobre o tema no ano 2000:

"fatti independenti dalla volontà del dichiarante, che di per sé rendono irripetibilli le dichiarazioni rese in precedenza, a prescindere dall'atteggiamento soggettivo" ${ }^{, 137}$.

"il giudice a quo mostra peraltro di non cogliere la differenza tra oggettiva impossibilità di ripetizione dell'assunzione dell'atto dichiarativo (quale potrebbe derivare da morte, irreperibilità, infermità che determina una totale amnesia del testimone), rientrante nella sfera di applicazione dell'art. 512 cod. proc. pen., e mera incapacità dedotta dal teste di

\footnotetext{
133 Tem natureza subjetiva a conduta ativa do acusado, testemunha ou réu acusador que tenha por objetivo, direto ou indireto, a frustração do contraditório na audiência de julgamento.

134 "Non dovuta ad una scelta volontaria della fonte di prova". In: CESARI, C. Giusto processo...op. cit., p. 69.

${ }^{135}$ Cf. UBERTIS, Giulio. Il contraddittorio nella formazione della prova penale. In: YARSHELL, Flávio Luis; MORAES, Maurício Zanoide (Org.). Estudos em homenagem ... op. cit., p.339.

${ }^{136}$ In: TONINI, Paolo. A prova ..., op. cit., p. 214.

${ }^{137}$ Sentença n ${ }^{\circ} 440$.
} 
richiamare alla memoria il contenuto dell'atto assunto durante le indagini preliminari, situazione appunto ravvisabile nel comportamento processuale di un testimone che afferma di non essere in grado di rispondere perché non ricorda fatti o circostanze riferiti in precedenza"138.

Por meio da expressão impossibilidade de caráter objetivo buscou o legislador constitucional italiano tutelar duas hipóteses: as provas de irrepetibilidade natural e as de irrepetibilidade superveniente.

Importante ressaltar que o conceito de impossibilidade de caráter objetivo vincula-se a dois pressupostos. Só será considerada impossível a repetição de prova por razões objetivas quando a irrepetibilidade (superveniente ou natural) derivar de um fato que não se podia prever (superveniente) no momento em que foi produzida ou que, sendo previsível, fosse impostergável (natural), pois o contrário levaria à perda definitiva da prova.

$\mathrm{Na}$ Itália, a avaliação da impossibilidade de caráter objetivo é questão incidental do processo criminal. Deste modo, as partes, em contraditório, podem produzir provas perante o juiz, a fim de comprovarem a existência ou inexistência dos pressupostos (impostergabilidade da prova irrepetível natural e imprevisibilidade da prova irrepetível superveniente), necessários à configuração da ressalva constitucional ao contraditório. Sobre o tema, TONINI ensina que a "impossibilidade de natureza objetiva não deve emergir, pela primeira vez, da motivação da sentença, mas deve ser objeto de prova e de discussão entre as partes. Sobre essa questão incidental, deve existir uma respectiva decisão do juiz. Assim, o contraditório é resgatado por meio do debate sobre a existência em concreto do requisito da impossibilidade objetiva e por meio da valoração sobre a idoneidade do elemento de prova que se extrai da precedente declaração. Dessa forma, a ratio da disposição em análise encontra-se 'no intento de evitar que o juiz influencie o método de formação da prova com base em valorações efêmeras, discricionárias, fundadas em elementos que não podem ser individualizados" $" 139$.

\footnotetext{
${ }^{138}$ Sentença $\mathrm{n}^{\mathrm{o}} 375$.

${ }^{139}$ In: TONINI, Paolo. A prova ..., op. cit., p. 214.
} 


\subsection{Aspectos relevantes e problemática relacionada à prova naturalmente irrepetível}

A impossibilidade objetiva que caracteriza como impossível a produção de prova naturalmente irrepetível em juízo decorre da certeza quanto à futura perda da fonte de prova, em razão de sua natureza transitória.

São provas naturalmente irrepetíveis os depoimentos prestados por quem esteja no leito de morte, os reconhecimentos, as perícias impostergáveis, as buscas, as apreensões, as interceptações telefônicas e outras que sejam consideradas urgentes.

O ponto mais discutido sobre a questão da irrepetibilidade natural relaciona-se ao grau de urgência da produção da prova. Distinguem-se na Itália as provas postergáveis das impostergáveis ${ }^{140}$.

Sob tal ótica, se a perda da fonte de prova for previsível, mas postergável (assim, é previsível que a testemunha, bastante idosa, possa falecer antes da audiência de julgamento em razão da avançada idade, mas não é esperado que isso ocorra imediatamente) a prova deve ser produzida em ato que possibilite a participação da acusação e da defesa, em contraditório concomitante. Em outros termos: havendo tempo, deve-se promover o "incidente probatório" para a colheita da prova.

O incidente probatório está previsto no artigo $392^{141}$ do Código de Processo Penal italiano e, conforme TRAMONTANO, "può essere definito come lo strumento processuale

\footnotetext{
${ }^{140}$ Cf. DI MARTINO, Corrada; PROCACCIANTI, Teresa. La prova...op. cit., p. 367.

141 "1. Nel corso delle indagini preliminari il pubblico ministero e la persona sottoposta alle indagini possono chiedere al giudice che si proceda con incidente probatorio: a) all'assunzione della testimonianza di una persona, quando vi è fondato motivo di ritenere che la stessa non potrà essere esaminata nel dibattimento per infermità o altro grave impedimento; b) all'assunzione di una testimonianza quando, per elementi concreti e specifici, vi è fondato motivo di ritenere che la persona sia esposta a violenza, minaccia, offerta o promessa di denaro o di altra utilità affinché non deponga o deponga il falso; c) all'esame della persona sottoposta alle indagini su fatti concernenti la responsabilità di altri; d) all'esame delle persone indicate nell'articolo 210 ; e) al confronto tra persone che in altro incidente probatorio o al pubblico ministero hanno reso dichiarazioni discordanti, quando ricorre una delle circostanze previste dalle lettere a) e b); f) a una perizia o a un esperimento giudiziale, se la prova riguarda una persona, una cosa o un luogo il cui stato è soggetto a modificazione non evitabile; g) a una ricognizione, quando particolari ragioni di urgenza non consentono di rinviare l'atto al dibattimento. 1-bis. Nei procedimenti per $i$ delitti di cui agli articoli 572, 609-bis, 609-ter, 609-quater, 609-quinquies, 609-octies, 612-bis, 600, 600-bis, 600-ter, anche se relativo al materiale pornografico di cui all'articolo 600-quater.1, 600-quinquies, 601 e 602 del codice penale il pubblico ministero, anche su richiesta della persona offesa, o la persona sottoposta alle indagini
} 
attraverso il quale è possibile compiere atti di acquisizione probatória durante la fase delle indagini preliminari, assumendo anticipatamente, di fronti al giudice e nel contraddittorio fra le parti, um novero di prove cui verrà riconosciuto pieno rilievo istruttorio nel giudizio" ${ }^{" 142}$. Trata-se da antecipação da audiência oral, mas sem a publicidade dos atos, própria da sessão de debates e julgamento. De acordo com a lei, o incidente probatório pode ser requisitado pela acusação e pela defesa na fase das investigações preliminares. E conforme previsão jurisprudencial (sentença $n^{0} 77$ da Corte Constitucional italiana, de 23 de janeiro de 1994), também na fase da audiência preliminar.

O ordenamento jurídico brasileiro disciplina instituto análogo ao incidente probatório italiano. Trata-se do ato de "produção antecipada de prova", previsto nos artigos 846 a 851 da lei processual civil (aplicáveis por analogia ao processo penal) e também no artigo 225 do Código de Processo Penal. Intimam-se as partes para comparecerem à audiência judicial, possibilitando-se, assim, o contraditório concomitante.

Somente a urgência, ligada à situação impostergável (como por exemplo, a interceptação de conversa telefônica ou a busca e apreensão), autoriza a produção de prova sem a utilização do incidente probatório (na Itália) ou do ato de produção antecipada de prova (no Brasil). Neste caso, deve-se certificar de que a prova foi obtida sem prévia comunicação às partes em razão de absoluta necessidade e impossibilidade. Essa orientação também é a adotada no Brasil ${ }^{143}$.

O problema de fundo do tema em questão consiste na dificuldade em se avaliar a real urgência existente à época da produção de algumas provas, colhidas pela polícia, sem a participação da defesa (quando esta poderia e deveria participar da formação da prova), ao

possono chiedere che si proceda con incidente probatorio all'assunzione della testimonianza di persona minorenne ovvero della persona offesa maggiorenne, anche al di fuori delle ipotesi previste dal comma 1. 2. Il pubblico ministero e la persona sottoposta alle indagini possono altresi chiedere una perizia che, se fosse disposta nel dibattimento, ne potrebbe determinare una sospensione superiore a sessanta giorni ovvero che comporti l'esecuzione di accertamenti o prelievi su persona vivente previsti dall'art. 224-bis".

${ }^{142}$ In: Codice di...op. cit., p. 944.

143 " A interceptação telefônica em tela tem natureza jurídica de medida cautelar preparatória da ação penal, concedida inaudita altera pars, pois sua divulgação frustraria o propósito da própria medida, o que, aliás, conclui-se da leitura do art. $1^{\circ}$, caput, da Lei n. 9.296/98. Aliada a tais características, tem-se que a prova produzida na interceptação é não repetivel. Em situações como essa, o princípio do contraditório é assegurado de maneira diferida, ou seja, após a realização do ato, quando oportunizada a manifestação das partes acerca das transcrições efetuadas" (Apelação Criminal nº 2010.038404-8/SC, Relator Moacyr de Moraes Lima Filho, 19/11/2010 - TJ/SC). 
argumento de que urgia a realização do ato, em razão de suposta impossibilidade de conservação da fonte de prova.

A valoração da questão da urgência na produção da prova é problemática, tanto no Brasil como na Itália, onde não existem regras objetivas e positivadas para sua aferição. Na maior parte das vezes, a aferição é feita, ao menos na Itália, por meio da análise do "verbale"144 e do material audiovisual ${ }^{145}$ utilizados no registro das ações policiais. Daí a importância das mídias eletrônicas na produção das provas, em especial daquelas colhidas fora do manto da publicidade e sem a possibilidade de participação das partes.

São normalmente urgentes e impostergáveis os procedimentos investigatórios, utilizados pela polícia na busca por fontes de prova. Passemos a sua análise.

Como dissemos no Capítulo I, os meios de investigação podem refletir práticas policiais corriqueiras (a ponto de não necessitarem de acompanhamento e autorização judicial, como, por exemplo, o ato de conservação do local do crime) ou complexas (invasivas a direitos constitucionais, como as interceptações telefônicas, que necessitam de autorização judicial). Ambas caracterizam atos naturalmente irrepetíveis.

A primeira hipótese é expressamente consentida pelo Código de Processo Penal italiano, que autoriza a execução de procedimentos investigatórios urgentes (sobre lugares, coisas e pessoas), mediante contraditório diferido (artigo 354). Ao tomar conhecimento de um crime, a polícia deve efetuar o necessário à garantia das fontes de prova (artigo 55), procurando coisas, zelando por sua conservação, investigando pessoas que possam trazer informações úteis ao processo (artigo 348), dentre outras atividades.

\footnotetext{
${ }^{144}$ No ordenamento jurídico italiano a documentação de um ato processual recebe a denominação de verbale e está disciplinada no artigo 134, inciso 1 do Código de Processo Penal ("Alla documentazione degli atti si procede mediante verbale").

${ }^{145}$ É notória a preocupação do legislador italiano com a garantia do contraditório sobre a prova. Observe-se, por exemplo, que o verbale que documente o interrogatório de suspeito detido deve ser instruído com meios de reprodução fonográfica e audiovisual, sob pena de inutilizabilidade (artigo 141 bis do Código de Processo Penal italiano: "Modalità di documentazione dell'interrogatorio di persona in stato di detenzione - 1. Ogni interrogatorio di persona che si trovi, a qualsiasi titolo, in stato di detenzione, e che non si svolga in udienza, deve essere documentato integralmente, a pena di inutilizzabilità, con mezzi di riproduzione fonografica o audiovisiva. Quando si verifica una indisponibilità di strumenti di riproduzione o di personale tecnico, si provvede con le forme della perizia, ovvero della consulenza tecnica. Dell'interrogatorio è anche redatto verbale in forma riassuntiva. La trascrizione della riproduzione è disposta solo se richiesta dalle parti".
} 
A segunda hipótese (utilização de meios de investigação invasivos) depende de autorização e fiscalização judicial. Trata-se de produção cautelar de prova (provas cautelares stricto sensu), que ocorre de forma sigilosa (vale dizer, sem a prévia intimação que possibilitaria ao suspeito ou seu defensor participarem do ato), em razão do elemento surpresa necessário ao êxito das investigações. Também nesta hipótese o contraditório é realizado de forma diferida.

O Código de Processo Penal italiano acolhe a possibilidade de utilização de provas cautelares, obtidas mediante autorização judicial, decorrentes de buscas (artigos 247 a 252), apreensões ${ }^{146}$ (artigos 253 a 265), inspeções ${ }^{147}$ (artigos 244 a 246), interceptações de conversas e comunicações $^{148}$ (artigo 264 a 271 CPP). No caso da identificação do suspeito incluir a necessidade de extração de amostras de cabelo ou sangue, e com isso ele não consentir, há a necessidade de autorização judicial ${ }^{149}$ (artigo 349).

No Brasil, podem ser citados como exemplos de provas cautelares em sentido estrito os meios operacionais para a prevenção e repressão de ações praticadas por organizações

\footnotetext{
${ }^{146}$ As apreensões podem relacionar-se ao corpo de delito (segundo o artigo 253 , inciso $2^{\circ}$, corpus delicti são coisas sobre as quais ou através das quais o crime foi cometido, além daquelas que compõem seu produto, lucro ou preço) e outros objetos, bens e valores relacionados à prática criminosa. A correspondência apreendida por policiais deve ser remetida ao Tribunal, sem que seja aberta ou que se tome contato com o conteúdo (se já houver sido encontrada aberta). Também é assegurado o sigilo e imutabilidade dos dados armazenados em meios tecnológicos.

${ }^{147}$ De lugares, pessoas e coisas. Note-se que no caso de a inspeção ser realizada em pessoa, esta deve ser avisada do direito de ser assistida por testemunha idônea, desde que esteja prontamente disponível.

${ }^{148}$ A interceptação é permitida para a obtenção de prova somente em casos de crimes de maior gravidade. É possível quando houver mandado judicial motivado, existirem indícios graves do cometimento do ilícito e quando a interceptação for absolutamente essencial para a continuidade das investigações. No caso de urgência, quando houver fundado motivo para acreditar-se que o atraso possa pôr em risco as investigações, a ordem para realização de interceptação telefônica pode ser dada pelo Ministério Público, que deverá transmiti-la ao Tribunal nas próximas 24 horas. Em tal situação o Tribunal deverá decidir em 48 horas sobre a validade da medida (se inválida, o resultado probatório não poderá ser usado no processo). Após a transcrição das conversas em verbale, este é entregue ao Ministério Público e é aberto prazo à defesa para que tome contato com a prova. A prova é, posteriormente, inserida no processo para o julgamento. $\mathrm{O}$ resultado da interceptação não pode servir como prova emprestada, vale dizer, não pode ser usado em outro processo além daquele para o qual foi autorizada a medida, salvo se indispensável para comprovação de um delito pelo qual é obrigatória a prisão em flagrante.

${ }^{149}$ Nesta hipótese passa-se de um procedimento investigatório simples a um invasivo, que retrata prova cautelar, dependente de autorização judicial, portanto. O artigo 360, inciso 5 do CPP italiano fala sobre as perícias técnicas não passíveis de repetição. No caso de o suspeito ter-se oposto à realização do exame nas investigações, a perícia realizada a contragosto pode ser usada para fundamentar a denúncia, mas não a decisão condenatória.
} 
criminosas (ações controladas, acesso aos dados, documentos e informações fiscais, bancárias, financeiras e eleitorais, captação e interceptação ambiental de sinais eletromagnéticos, óticos ou acústicos e agentes infiltrados, contidos na Lei $n^{\circ}$ 9.034/95), as buscas e apreensões (artigos 240 a 250 do Código de Processo Penal), as interceptações de comunicações telefônicas (Lei $n^{0}$ 9.296/96), as quebras do sigilo de operações de instituições financeiras para a investigação de crimes graves (como o terrorismo, tráfico ilícito de substâncias entorpecentes ou drogas afins, contrabando ou tráfico de armas, munições ou material destinado a sua produção, extorsão mediante sequestro, contra o sistema financeiro nacional, contra a Administração Pública, contra a ordem tributária e a previdência social, lavagem de dinheiro - Lei Complementar $\left.n^{\circ} 105 / 01\right)$, dentre outros.

Diferentemente do que ocorre com os meios de investigação urgentes, os meios de produção de prova urgentes são, no mais das vezes, postergáveis - ao menos pelo lapso temporal suficiente a possibilitar a marcação de audiência judicial de antecipação da prova. Sendo postergáveis, devem, obrigatoriamente, ser utilizados de modo a permitir a atuação das partes em contraditório concomitante. Somente se impostergáveis poderão os elementos de prova, deles resultantes, ser utilizados no julgamento (e ainda assim, somente quando for possível o contraditório diferido).

Analisemos a questão da irrepetibilidade natural com relação a alguns meios de prova (testemunhos, perícias, reconhecimentos e documentos):

\section{Testemunhos}

Quanto à prova testemunhal antecipada não há grandes debates no Brasil, e seu regramento se assemelha ao do processo penal italiano. Pode-se antecipar o testemunho em razão da previsibilidade de que o declarante ausente-se do julgamento, ou quando sua enfermidade ou idade avançada levarem a crer que já não exista (ou que esteja incapacitado de depor) a este tempo ${ }^{150}$. Segundo a lei processual civil brasileira, a prova oral antecipada deve ser

\footnotetext{
150 "Far-se-á o interrogatório da parte ou a inquirição das testemunhas antes da propositura da ação, ou na pendência desta, mas antes da audiência de instrução: I - se tiver de ausentar-se; II - se, por motivo de idade ou de moléstia grave, houver justo receio de que ao tempo da prova já não exista, ou esteja impossibilitada de depor" (artigo 847 do Código de Processo Civil). "Se qualquer testemunha houver de ausentar-se, ou, por enfermidade ou por velhice, inspirar receio de que ao tempo da instrução criminal já não exista, o juiz
} 
produzida em audiência conduzida pela autoridade judicial, na presença das partes, em contraditório concomitante ${ }^{151}$.

\section{Perícias}

As perícias também podem ser antecipas ${ }^{152}$, mas sobre elas cabem algumas considerações. Segundo o Código de Processo Penal italiano, as perícias produzidas em incidente probatório devem ser autorizadas e presididas por juiz, que deve notificar as partes sobre o direito a serem assistidas por advogados, a nomearem assistentes técnicos e a participarem da produção da prova no local, dia e hora marcados pelo perito para a realização do ato (artigo 229, inciso 1). Os assistentes técnicos podem participar do incidente probatório apresentando quesitos, fazendo observações (que devem ser documentados juntamente com o ato de produção da prova), e pedidos ao juiz (artigo 230, inciso 1 e 2). No caso de a parte optar por indicar assistente técnico somente após a realização da perícia (e não antes dela, como faculta a lei), este poderá examinar a documentação do ato e requerer ao magistrado a autorização para reexaminar a fonte de prova (coisa, pessoa ou local - artigo 230, inciso 3). Ressalte-se que a participação dos interessados (partes e assistentes técnicos) é garantida na fase da investigação somente quando suas atividades não prejudicarem ou retardarem a execução da perícia, pois, nestes casos, assegura-se o contraditório na modalidade diferida (artigo 230, inciso 4).

Semelhante é a disposição contida na lei processual civil brasileira de que a prova pericial deve ser realizada após notificação das partes sobre a data e o local em que terá início a prova pericial. A orientação busca possibilitar que os interessados possam participar da produção da prova, indicar assistentes técnicos (que poderão elaborar quesitos antes ou durante a realização do ato de prova) e utilizar os meios necessários ao bom

poderá, de oficio ou a requerimento de qualquer das partes, tomar-lhe antecipadamente o depoimento" (artigo 225 do Código de Processo Penal).

151 "Tratando-se de inquirição de testemunhas, serão intimados os interessados a comparecer à audiência em que prestará o depoimento" (artigo. 848, parágrafo único do Código de Processo Civil).

152 "Havendo fundado receio de que venha a tornar-se impossivel ou muito difícil a verificação de certos fatos na pendência da ação, é admissivel o exame pericial" (artigo 849 do Código de Processo Civil). "A prova pericial realizar-se-á conforme o disposto nos artigos. 420 a 439" (artigo 850 do Código de Processo Civil). 
desenvolvimento da produção da prova (como ouvir testemunhas, obter documentos ou informações e instruir o laudo com peças que entender pertinentes) ${ }^{153}$.

Mas tais preceitos não são adotados em sua inteireza no processo penal. Com efeito, as regras que asseguram a participação dos interessados no ato de realização da prova pericial não são garantidas de forma ampla no processo penal, nem mesmo com relação às perícias produzidas em juízo. Muito embora os artigos $159, \S 3^{\circ}$ e 176 do Código de Processo Penal facultem às partes a formulação de quesitos (até o ato da diligência pericial) e a indicação de assistentes técnicos, o $\S 4^{\circ}$ do artigo 159 da mesma lei prevê que estes somente atuarão "a partir de sua admissão pelo juiz e após a conclusão dos exames e elaboração do laudo pelos peritos oficiais".

Assim, a função desempenhada pelos assistentes técnicos - que no processo penal italiano e no processo civil brasileiro é, antes de tudo, a de participar ativamente da produção da prova pericial, com a qual têm contato antes mesmo de sua realização - é, no processo penal pátrio, limitada à emissão de parecer sobre perícia já realizada, após a elaboração do laudo pelo perito oficial. E isso restringe sua atuação à mera análise da qualidade do laudo, das conclusões nele contidas e da idoneidade do perito.

Situação ainda mais complicada é observável quanto às perícias produzidas durante o inquérito policial. Nestes casos, além de ser impossível a atuação de assistentes técnicos (pelos motivos acima expostos), é inviável a apresentação de quesitos pelas partes - pois antes de ser instaurada a relação processual (que nasce com o recebimento da denúncia) não existem acusados, querelantes, ofendidos e assistentes de acusação, que poderiam, de acordo com a lei (artigo 176 do Código de Processo Penal), apresentar seus quesitos antes da realização da diligência.

\footnotetext{
${ }^{153}$ Cf. as seguintes normas do Código de Processo Civil: "Artigo 420. A prova pericial consiste em exame, vistoria ou avaliação. Artigo. 421. $\S 1^{\circ}$ Incumbe às partes, dentro em 5 (cinco) dias, contados da intimação do despacho de nomeação do perito: I-indicar o assistente técnico; II-apresentar quesitos. Artigo. 425. Poderão as partes apresentar, durante a diligência, quesitos suplementares. Da juntada dos quesitos aos autos dará o escrivão ciência à parte contrária. Artigo. 429. Para o desempenho de sua função, podem o perito e os assistentes técnicos utilizar-se de todos os meios necessários, ouvindo testemunhas, obtendo informações, solicitando documentos que estejam em poder de parte ou em repartições públicas, bem como instruir o laudo com plantas, desenhos, fotografias e outras quaisquer peças. Artigo 431-A. As partes terão ciência da data e local designados pelo juiz ou indicados pelo perito para ter início a produção da prova”.
} 
A doutrina brasileira tece críticas quanto à impossibilidade do indiciado apresentar quesitos antes da produção de prova pericial, especialmente com relação a situações de moderada urgência (ou, na classificação italiana, provas urgentes postergáveis), em que seria possível sua notificação sobre a realização da diligência ${ }^{154}$.

Todavia, em razão de a lei processual penal ser clara quanto à impossibilidade de participação do suspeito, seu defensor ou assistente técnico nas perícias realizadas na fase inquisitiva da persecução penal, tem-se lhes atribuído valor probatório ${ }^{155}$. Sua validade baseia-se no argumento de que não haveria prejuízo à ampla defesa, pois a validade e a eficácia da prova pericial podem ser cotejadas, posteriormente, pelo julgador e pelas partes $^{156}$. Nestes casos, o contraditório é diferido para o momento da nomeação dos

\footnotetext{
${ }^{154}$ Cf. FERNANDES, Antonio Scarance. Processo Penal... op. cit., 6 ${ }^{\mathrm{a}}$ ed., p. 64 ("Excluídos os casos em que há urgência, seja porque há risco de desaparecerem os sinais do crime, seja porque é impossível ou difícil conservar a coisa a ser examinada, ou ainda as hipóteses em que inexiste suspeita contra pessoa determinada, a autoridade policial deveria dar oportunidade ao indiciado de apresentar quesitos para maior garantia de defesa"); NUCCI, Guilherme de Souza, Código de ...op. cit., p. 395 ("É evidente que durante a investigação policial o indiciado não é considerado parte, nem tem direito à produção de prova, pois o procedimento é inquisitivo. Mas, por outro lado, não se deve perder de vista que muitas provas são préconstituídas, isto é, não serão novamente realizadas durante a instrução judicial, tornando-se definitivas. Nesse caso, como se poderia evitar que o indiciado participasse de sua produção, sem ferir o direito ao contraditório e à ampla defesa? Caso lhe seja retirada tal oportunidade, cremos que o exame pode ser refeito durante a instrução, a seu pedido. Entretanto, há determinadas perícias que não mais podem ser realizadas com sucesso, caso decorra muito tempo, de maneira que é preciso adaptar o processo penal à nova Constituição Federal, que deixou bem clara a existência dos princípios processuais mencionados. Defendemos, pois, que o indiciado, por seu defensor, pode apresentar quesitos na fase extra-judicial, quando se tratar de prova pericial pré-constituida"); GOMES, Luiz Flávio. Comentários às Reformas do Código de Processo Penal e da Lei de Trânsito, $1^{\mathrm{a}}$ ed., São Paulo: Revista dos Tribunais, 2008, p. 291-292 ("Adespeito dos termos peremptórios do dispositivo, poderia ter o legislador avançado mais ainda, a fim de permitir a presença, na fase inquisitorial, do assistente técnico. Afinal, é sabido que a prova pericial, em razão de suas peculiaridades, na maioria das vezes não admite repetição em juízo”).

${ }^{155}$ Cf. FERNANDES, Antonio Scarance. Processo Penal... op. cit., 6a ed., p. 83 ("maior problema existe quanto à prova pericial produzida na fase policial. Admite-se a sua realização como prova definitiva quando há urgência, postergando-se o contraditório para momento posterior, em que as partes poderão contestar o laudo, elaborar quesitos suplementares, pedir esclarecimento aos peritos. É o que ocorre quando há perigo de desaparecer o corpo de delito, como acontece com a lesão produzida no corpo da vitima, que normalmente só permanece por determinado tempo. Não se justifica, contudo, prova pericial sem contraditório prévio na fase policial se inexiste perigo de os vestígios desparecerem. Caso venha a ser realizada, as partes têm o direito de requererem, em juízo, nova perícia") e CINTRA, Antônio Carlos de Araújo; GRINOVER, Ada Pellegrini; DINAMARCO, Cândido Rangel. Teoria Geral...op. cit., p.63 ("se não houver contraditório, os elementos probatórios do inquérito não poderão ser aproveitados no processo, salvo quando se tratar de provas antecipadas, de natureza cautelar (como o exame de corpo de delito, em que o contraditório é diferido").

156 "A prova pericial, por exemplo, que não tem outro jeito senão o de ser realizada na fase investigatória, não somente porque a urgência é imperiosa, mas porque muitas vezes não há sequer alguém suspeito, tem o contraditório diferido, porque, em juizo, o acusado tem a oportunidade de contrapor-se a ela, demonstrando, se for o caso, a sua falha técnica, a impropriedade da colheita, a inaptidão do perito e outras circunstâncias
} 
assistentes técnicos, que poderão tomar contato com o material que serviu à perícia (quando possível sua conservação) ${ }^{157}$ e impugnar o exame realizado na fase inquisitiva da persecução penal, requerendo nova produção da prova pericial ou esclarecimentos complementares dos peritos ${ }^{158}$. Incluem-se nesta categoria, por exemplo, a perícia do local dos fatos, o exame de corpo de delito ${ }^{159}$, o exame necroscópico ${ }^{160}$ e o teste de bafômetro ${ }^{161}$.

É importante ressaltar, que o Código de Processo Penal italiano também autoriza, excepcionalmente, que a produção de prova pericial (e de outras provas urgentes e não repetíveis) ocorra sem a utilização do incidente probatório, ou seja, sem a participação do juiz ou das partes, em contraditório concomitante ${ }^{162}$. Neste caso, deve-se comprovar que a

que possam comprometer a sua credibilidade" (In: GRECO FILHO, Vicente. Manual de ...op. cit., p. 204205); “(...) como a maioria das perícias se realiza durante o inquérito policial em que não há partes, estas formularão seus quesitos especiais em juizo, depois de instaurada a ação penal, com quesitos complementares, cuja pertinência será examinada pelo juiz" (In: GRECO FILHO, Vicente. Manual de ...op. cit., p. 207).

${ }^{157}$ No caso de haver requerimento das partes, o material probatório que serviu de base à perícia será disponibilizado no ambiente do órgão oficial, que manterá sempre sua guarda, e na presença de perito oficial, para exame pelos assistentes, salvo se for impossível a sua conservação (artigo $159, \S 6^{\circ}$ do Código de Processo Penal).

${ }_{158}$ Cf. FERNANDES, Antonio Scarance. Processo Penal... op. cit., 6 ${ }^{\mathrm{a}}$ ed., p. 64.

${ }^{159}$ Deve-se obrigatoriamente realizar exame de corpo de delito nos crimes que deixam vestígios, entre eles, por exemplo, o estupro, a lesão corporal, o homicídio, a embriaguez na direção de veículo automotor e o arrombamento. $\mathrm{O}$ exame de corpo de delito é "a perícia sobre os vestígios da infração, que são as alterações materiais deixadas pela conduta criminosa" (cf. GRECO FILHO, Vicente. Manual de ...op. cit., p. 207.). O exame de corpo de delito pode ser feito diretamente, por perito oficial (ou, na sua falta, por duas pessoas idôneas, com habilitação técnica na área), ou indiretamente, por testemunhas, nos termos do artigo 158 do Código de Processo Penal brasileiro. Cf. BADARÓ: "Para a prova pericial produzida durante o inquérito policial tem sido aceita, com tranqüilidade, a possibilidade de o juiz valorá-la no momento da sentença. A razão é que é se trata de um prova cautelar, produzida antecipadamente, tendo em vista que, na maioria dos casos, deve ser realizada desde logo, diante do risco de perecimento dos objetos a serem examinados. Exemplo mais evidente dessa situação é o corpo de delito, ou outras formas de exame pericial" (In: Direito Processual...op. cit., p. 64).

160 "O laudo necrópsico, por exemplo, quando o perito examina o cadáver da vítima do homicídio, é prova não repetível, vez que, posteriormente, ainda que se realize a exumação do corpo, o objeto já não será o mesmo e a perícia não produzirá o efeito desejado”. In: NUCCI, Guilherme de Souza. Provas no Processo Penal, São Paulo: Revista dos Tribunais, 2009, p. 20.

161 "Por outro lado, não se pode olvidar que o artigo 155, caput, do Código de Processo Penal, apesar de proibir que o juiz decida apoiado somente nos elementos coligidos no inquérito policial, abre exceção às provas irrepetíveis, como é o caso do teste no aparelho de ar alveolar pulmonar" (Apelação n 000654104.2009.8.26.0400, Relator Hermann Herschander - TJSP).

${ }^{162}$ Artigo 360 do Código de Processo Penal italiano. "Accertamenti tecnici non ripetibili. 1. Quando gli accertamenti previsti dall'articolo 359 riguardano persone, cose o luoghi il cui stato è soggetto a modificazione, il pubblico ministero avvisa, senza ritardo, la persona sottoposta alle indagini, la persona offesa dal reato e i difensori del giorno, dell'ora e del luogo fissati per il conferimento dell'incarico e della facoltà di nominare consulenti tecnici. 2. Si applicano le disposizioni dell'articolo 364 comma 2. 3. I difensori nonché $i$ consulenti tecnici eventualmente nominati hanno diritto di assistere al conferimento dell'incarico, di partecipare agli accertamenti e di formulare osservazioni e riserve. 4. Qualora, prima del conferimento dell'incarico, la persona sottoposta alle indagini formuli riserva di promuovere incidente probatorio, il pubblico ministero dispone che non si proceda agli accertamenti salvo che questi, se differiti, 
perícia era impostergável, de modo que sua não realização frustraria definitivamente a produção da prova. Somente assim está legitimada a restrição ao contraditório concomitante. Mas note-se, ele é obrigatório e, portanto, deve ser feito de forma postergada.

\section{Reconhecimentos}

A leitura dos artigos 214 a 217 do Código de Processo Penal italiano leva ao entendimento de que reconhecimento é meio de prova a ser realizado exclusivamente na presença de juiz, quer durante a audiência preliminar, quer durante a audiência de julgamento ou, se necessário na etapa das investigações, em incidente probatório. $\mathrm{O}$ mesmo entendimento é alcançado na doutrina: "le ricognizioni, in quanto tali, sono sempre tipiche di fasi caratterizzate dalla presenza del giudice; e al giudice spetta per intero la conduzione delle operazioni, ${ }^{, 163}$.

Assim, predomina na Itália o entendimento de que o reconhecimento não se confunde, nem é invalidado, pelo ato informal de identificação do suspeito, realizado pela polícia ou pelo Ministério Público durante as investigações. De acordo com a doutrina, se a identificação do suspeito, por vítima ou testemunha (que é um ato informal e urgente, feito no início das investigações), fosse entendida como um primeiro reconhecimento (que é meio de prova formal), estar-se-ia supondo que o reconhecimento é um meio de prova repetível (já que outro, depois dele, se seguiria) quando, na verdade, trata-se de prova naturalmente irrepetível $^{164}$.

non possano più essere utilmente compiuti. 5. Se il pubblico ministero, malgrado l'espressa riserva formulata dalla persona sottoposta alle indagini e pur non sussistendo le condizioni indicate nell'ultima parte del comma 4, ha ugualmente disposto di procedere agli accertamenti, i relativi risultati non possono essere utilizzati nel dibattimento".

${ }^{163}$ Cf. CHIAVARIO, Mario. Processo e ...op. cit., p. 335.

164 "Ocorre infine precisare che tra l'individuazione di persone, svolta dal pubblico ministero durante le indagini preliminari, e la ricognizione non sussiste alcun rapporto di alternatività, cosicché, una volta disposta la prima, non potrebbe mai procedersi alla seconda. Ove, infatti, si seguisse una simile linea interpretativa si sovrapporrebbero surrettiziamente le nozioni di atto non rinviabile e di atto non ripetibile, risultando l'individuazione, come tale, sempre ripetibile (salvo che l'oggetto di esso sia nel frattempo venuto meno) attraverso il mezzo di prova rapresentato dalla ricognizione". In: TRAMONTANO, Luigi. Codice di ...op. cit., p. 499-500. 
No Brasil, a moderna doutrina também classifica o reconhecimento como prova naturalmente irrepetível. Segundo FERNANDES, um "o ato irrepetível, por natureza, é o reconhecimento pessoal, quando positivo, pois não se pode reconhecer novamente o antes reconhecido" $" 165$. No mesmo sentido é o entendimento de LOPES: "o reconhecimento é meio de prova capaz de produzir elementos de prova quando realizado na presença de um juiz e em respeito às garantias do devido processo legal. Este meio de prova, em razão da especial natureza que o reveste, é um ato definitivo e irreprodutivel, pois não pode ser repetido em condição idêntica" ${ }^{\prime 166}$.

A irrepetibilidade natural do ato de reconhecimento está ligada à natureza falível da memória humana. LOPES, citando Eduardo M. Jauchen, esclarece que "o fato de o reconhecedor expressar um juizo de identidade quando lhe são exibidas pessoas ou coisas, configura experiência que uma vez efetuada e obtido um resultado, positivo ou negativo, tornará ineficaz uma nova realização, pois a imagem incorporada nesse ato interferirá na cadeia da memória da pessoa. Assim, perderia toda a eficácia probatória a eventual realização de um segundo reconhecimento" ${ }^{\prime 167}$.

Não é recente a percepção de que o reconhecimento é uma prova falha, pois " $a$ ação do tempo, o disfarce, as más condições de observação, os erros por semelhança, a vontade de reconhecer, tudo, absolutamente tudo, torna o reconhecimento uma prova altamente precária"168. E por ser prova precária, deve ser produzida uma única vez.

É interessante notar que o Código de Processo Penal brasileiro não afirma que, para ser válido, deve o reconhecimento ser judicializado (como o faz, por exemplo, com a prova testemunhal). Segundo a lei processual penal brasileira o reconhecimento deve ser efetuado "quando houver necessidade" (artigo 226 do Código de Processo Penal), perante "autoridade" (genericamente mencionada no inciso III do artigo 226, abrangendo, assim, os conceitos de autoridade judicial e policial). Sua validade está relacionada ao respeito ao

\footnotetext{
${ }^{165}$ In: FERNANDES, Antonio Scarance Fernandes. Processo Penal... op. cit., $6^{\mathrm{a}}$ ed., p. 66.

${ }^{166}$ In: LOPES, Mariângela Tomé. O reconhecimento como meio de prova - necessidade de reformulação do direito brasileiro. Tese de doutorado defendida na Faculdade de Direito da Universidade de São Paulo, São Paulo, 2011, p. 31-32.

${ }^{167}$ In: LOPES, Mariângela Tomé. O reconhecimento...op. cit., p. 32.

${ }^{168}$ In: TOURINHO FILHO, Fernando da Costa. Manual de Processo ...op.cit., $12^{\mathrm{a}}$ ed., p. 569.
} 
procedimento estabelecido na lei, independentemente de realizar-se na fase investigativa ou na judicial ${ }^{169}$.

Pensamos que o reconhecimento deva ser feito, preferencialmente, na etapa das investigações, em razão de a proximidade temporal do crime favorecer a correta percepção dos fatos ilícitos e a identificação dos criminosos ${ }^{170}$.

Embora o artigo 226 do Código de Processo Penal não o determine, entendemos que a participação de defensor no ato de reconhecimento da etapa investigativa seja necessária (quer para a garantia de um contraditório eficiente, quer para que se evitem posteriores requerimentos de anulação do ato de produção da prova, por cerceamento aos direitos de defesa ou desrespeito ao procedimento), somente podendo-se dela prescindir em razão de urgência $^{171}$.

Em outras palavras, o reconhecimento realizado nas investigações deve seguir as regras de antecipação da prova (audiência judicial, participação da defesa e da acusação em contraditório concomitante, com respeito ao procedimento estabelecido no artigo 226 do Código de Processo Penal brasileiro), com exceção dos casos em que a urgência demande sua imediata realização pela autoridade policial (hipótese em que o contraditório pode ser diferido) ${ }^{172}$.

169 O desrespeito às formalidades prescritas no artigo 226 do Código de Processo Penal pode ensejar a nulidade da prova colhida ("Reconhecimento de pessoa - Sua realização sem a observância do procedimento determinado imperativamente pelo artigo 226 do CPP elide sua força probante" - JSTF 216/393). Há, todavia, entendimento no sentido de que a desobediência às prescrições especificadas na lei não torna $o$ ato viciado, somente o transmuta em outro meio de prova, como a testemunhal ("Para que se possa invocar ter havido o reconhecimento de alguém ou de algo, é fundamental a preservação da forma legal. não tendo sido possivel, o ato não foi perdido por completo, nem deve ser desprezado. Apenas não receberá o cunho de reconhecimento de pessoa ou coisa, podendo constituir-se numa prova meramente testemunhal, de avaliação subjetiva, que contribuirá ou não para a formação do convencimento do magistrado. Logicamente, perde sua força, embora não seja desprezível”. In: NUCCI, Guilherme de Souza, Código de ...op. cit., p. 497-498).

170 "O reconhecimento pessoal feito na polícia têm grande valor, sobrepondo-se às dúvidas que os reconhecedores apresentam diante de um reconhecimento judicial, realizado anos mais tarde, mesmo porque, à época do inquérito, as imagens do evento estão mais frescas na mente do reconhecedor" (RJDTACrim 9/138).

${ }^{171}$ No mesmo sentido, FERNANDES: "Nem sempre será urgente e, por isso, cautelar. Quando isso ocorrer, na sua efetivação deve ser permitida a participação do Ministério Público e do advogado do suspeito ou de advogado nomeado". In: FERNANDES, Antonio Scarance. Processo Penal... op. cit., $6^{\mathrm{a}}$ ed., p. 66.

${ }^{172}$ (...) "é possivel afirmar que se pode constituir em prova antecipada, visto que deve ser realizada o mais rápido possivel e, por haver a previsibilidade de sua realização, é possível que se produza com a participação das partes e do juiz, em respeito ao contraditório, que se forma, nesse caso, 


\section{Documentos}

Entendemos que dentre as hipóteses relacionadas ao estudo da irrepetibilidade probatória (prova repetível perfeita, prova repetível imperfeita, prova naturalmente irrepetível e prova de irrepetibilidade superveniente) a prova documental mais se aproxima da prova naturalmente irrepetível ${ }^{173}$.

Com efeito, o documento não poderia ser classificado como prova de irrepetibilidade superveniente, pois a impossibilidade de sua produção no julgamento é conhecida de antemão (haja vista tratar-se de prova pré-constituída, ou seja, formada antes do processo). Também não poderia dizer-se repetível (perfeita ou imperfeita) por não haver qualquer possibilidade de repetição da prova em juízo: o que ocorre, em verdade, é a mera leitura do documento, que não se confunde com produção de prova documental, em contraditório concomitante. Segundo TONINI, "o escrito deve ser lido e, nesse sentido, pode ser expresso oralmente, assim como pode ser produzida uma gravação; mas trata-se de uma oralidade fictícia. Aquele que escuta pode ouvir um monólogo ou um diálogo, mas não pode 'participar', não pode fazer perguntas nem obter respostas da pessoa que, anteriormente, prestou declarações escritas ou gravadas" ${ }^{\prime 174}$.

Se aproxima, portanto, do conceito de prova naturalmente irrepetível, em razão de sua natureza (pré-constituída). São documentos, por exemplo, a carta que a vítima recebeu em ameaça, antes do cometimento de seu assassinato, as gravações de circuito interno de segurança do local onde o roubo ocorreu, o conteúdo de mídias eletrônicas que guardem informações relacionadas à prática de um delito (como CD, DVD, pen drive).

concomitantemente. Caso haja impossibilidade de chamamento das partes, permite-se, excepcionalmente, o contraditório diferido" (In: LOPES, Mariângela Tomé. O reconhecimento...op. cit., p. 32-33)

173 No mesmo sentido: "A prova documental, produzida na época dos fatos, ou no momento da obtenção de elementos a eles alusivos, é em regra irrepetivel, enquadrando-se na ressalva da parte final do art. 155 do $C P P$, mormente quando submetida ao contraditório no processo penal. Na hipótese, os documentos surgiram com o início da auditoria do INSS e do procedimento revisional, processo administrativo invalidador que inclusive garante oportunidade defesa ao segurado, sob pena de invalidade. 3. Além disso, ante à colação dos documentos na ação penal, foram eles franqueados à defesa para contraditá-los, seja impugnando sua veracidade, seja impugnando a validade de sua obtenção (...) 5. Apelação provida" (TRF2, ACR 200951018106482, Relator Marcello Ferreira de Souza Granado, 21/06/2011).

${ }^{174}$ In: TONINI, Paolo. A prova ..., op. cit., p. 88. 
O contraditório exercido sobre a prova documental é diferido, e seu valor probatório é analisado à guia dos demais elementos de prova do processo. Nesta análise, deve o juiz avaliar se o escrito ou a gravação (ou demais espécies de documentos) contém informações fidedignas e se foi confeccionado com respeito às normas de direito material.

Discute-se na Itália se o valor do documento como prova acolheria a possibilidade de valoração das declarações nele contidas (dito de outro modo, discute-se a possibilidade de utilização das declarações escritas para fundamentar a sentença condenatória) ou referir-seia apenas aos aspectos formais do ato reproduzido na base material (vale dizer, se serviria somente para atestar, por exemplo, que seu subscritor estava vivo na data de sua confecção e que essa deu-se em determinado local). A Corte Constitucional italiana, por meio da sentença 142 de 1992, fez a análise do tema em questão, optando pela interpretação ampliativa de seu valor probatório, ao argumento de que, ao definir documento, o artigo 234 do Código de Processo Penal italiano referiu-se à "representação de um fato", sem que mencionasse o aspecto dessa representação que deveria ser valorado, cabendo ao magistrado, por meio do livre convencimento motivado, analisar casuisticamente a questão $^{175}$.

Diferente do documento é o ato de documentação, conforme explicamos no Capítulo I do trabalho. Enquanto o primeiro é meio de prova, o segundo é a forma pela qual os atos procedimentais (dentre eles, os que se relacionam à produção de provas) são registrados em suporte material. No Brasil a documentação dos atos processuais ocorre através da confecção de "termos" "176, enquanto na Itália, como explicamos neste mesmo Capítulo, ocorre pela confecção de "verbales". Os termos e os verbales, diferentemente dos documentos, podem conter o registro de provas repetíveis e de provas não repetíveis.

É possível a utilização de termos e verbales de outros processos (que contenham o registro de provas como depoimentos, perícias, reconhecimentos e mesmo documentos) para o fim

\footnotetext{
${ }^{175}$ Cf. TONINI, Paolo. A prova ..., op. cit., p. 197-199.

176 "Chama-se termo a documentação escrita de atos processuais, feita por serventuário da justiça. Como existem atos que se realizam oralmente e precisam ficar documentados no processo (p. ex., os atos praticados em audiência), sua documentação faz-se através de termos (CPC, art. 427; CLT, art. 832)". CINTRA, Antônio Carlos de Araújo; GRINOVER, Ada Pellegrini; DINAMARCO, Cândido Rangel. Teoria Geral...op. cit., p. 361. Note-se que, atualmente, tanto a lei dos juizados especiais como o Código de Processo Penal brasileiro autorizam a gravação por imagem e som.
} 
de compor o conjunto probatório que será avaliado na audiência de julgamento: trata-se da possibilidade de leitura de "provas emprestadas" $" 177$.

Segundo as normas de direito italianas, as provas emprestadas repetíveis e as naturalmente irrepetíveis ${ }^{178}$ podem ser utilizadas quando presentes três requisitos: (i) terem sido produzidas em incidente probatório ou durante a audiência de julgamento do processo original (sendo vetadas quando produzidas durante as investigações); (ii) referirem-se ao mesmo acusado; e (iii) terem o réu e seu advogado participado do ato original de colheita da prova, a fim de que se preserve a garantia do contraditório na formação da prova. Ou, alternativamente, quando o réu consentir com seu uso.

Aquele que pretender trazer aos autos uma prova emprestada deverá requerer, antes da audiência de julgamento, sua admissão no processo ao qual servirá, e tal pedido será avaliado pelo juiz ${ }^{179}$. Se houver autorização judicial para o ingresso da prova emprestada nos autos, os interessados terão o direito a examiná-la e deverão consentir com seu ingresso no arquivo de provas do julgamento ${ }^{180}$.

\subsection{Aspectos relevantes e problemática relacionada à prova de irrepetibilidade superveniente}

A impossibilidade objetiva relacionada à prova de irrepetibilidade superveniente liga-se à inesperada modificação ou extinção da fonte de prova, que a princípio seria repetida no julgamento.

O legislador infraconstitucional italiano regulamentou a possibilidade de utilização destas provas no artigo 512 do Código de Processo Penal (“o juiz, a pedido das partes, autoriza que se dê a leitura de atos praticados pela polícia judiciária, pelo Ministério Público, pelo

\footnotetext{
${ }^{177}$ Cf. artigo 511 bis do Código de Processo Penal italiano.

178 A prova emprestada de irrepetibilidade superveniente será tratada no próximo item deste Capítulo. A possibilidade de uso da prova emprestada (repetível e irrepetível) no processo penal italiano está regulamentada no artigo 238 do Código de Processo Penal italiano.

${ }_{179}$ Cf. artigo 468, inciso 4bis do Código de Processo Penal italiano.

${ }^{180}$ Cf. artigo 495, inciso 3 do Código de Processo Penal italiano.
} 
defensor da parte privada e pelo juiz no curso da audiência preliminar quando, por fato ou circunstância imprevisível, tornou-se impossivel a repetição" ${ }^{, 181}$ ).

A irrepetibilidade superveniente liga-se a casos em que testemunhas, réus acusadores, vítimas e outras pessoas que deveriam declarar em juízo deixam de fazê-lo, por razões imprevisíveis e independentes da vontade humana. Três são as hipóteses que lhe dão causa: (i) a morte inesperada do depoente; (ii) a enfermidade que repentinamente acomete o depoente; e (iii) o desaparecimento do depoente ${ }^{182}$.

No caso de ter sido a morte ou a enfermidade do declarante que tornaram impossível a repetição da prova no julgamento, a leitura das declarações feitas em fases anteriores do processo somente será realizada se houver comprovação de que o evento que lhe deu causa era realmente imprevisível (como, por exemplo, a morte abrupta ou a sequela mental causada na vítima em razão de acidente automobilístico ${ }^{183}$ ). Constatando-se que este era previsível a leitura não será consentida pelo juiz, haja vista que a prova deveria ter sido produzida em incidente probatório, conforme orientação da lei ${ }^{184}$.

Há situações em que a enfermidade traduz-se em doença mental degenerativa, mas controlável. Nestes casos, a avaliação da possibilidade do agravamento da doença é praticamente impossível, razão pela qual esta hipótese tem sido aceita na Itália para comprovar a impossibilidade objetiva e superveniente de repetição da prova em juízo. Mas

\footnotetext{
${ }^{181}$ Tradução livre. "Il giudice, a richiesta di parte, dispone che sia data lettura degli atti assunti dalla polizia giudiziaria, dal pubblico ministero, dai difensori delle parti private e dal giudice nel corso della udienza preliminare quando, per fatti o circostanze imprevedibili, ne è divenuta impossibile la ripetizione”.

${ }^{182}$ Tais hipóteses encontram assento no artigo 195, inciso 3 do Código de Processo, que prevê a excepcional possibilidade de aceitação de testemunho indireto quando o exame testemunhal direto tenha se tornado impossível em razão de morte, enfermidade ou ausência ("morte, infermità o irreperibilità").

${ }^{183}$ Note-se, ademais, que a Corte de Cassação italiana tem caracterizado também o suicídio como causa de irrepetibilidade superveniente (Cass., Sez. I, 22.11.2002, Chivasso, $\mathrm{n}^{\mathbf{0}}$ 223253), ao argumento de que a intenção do declarante é a de ceifar a própria vida, não a de subtrair-se voluntariamente ao contraditório (hipótese que caracterizaria, segundo nossa classificação, a prova repetível imperfeita).

184 "quando sopravviene la morte del testimone, per ammettere la lettura della dichiarazione ex art. 512 c.p.p. è necessário valutare se già durante le indagini preliminari questo dichiarante si trovasse in uno stato di infermità tale da consigliare il ricorso all'incidente probatorio ex art. 392, $1^{\circ}$ comma, lett. a) c.p.p.”. In: DI MARTINO, Corrada; PROCACCIANTI, Teresa. La prova...op. cit., p. 368.
} 
note-se, há necessidade de parecer médico no sentido de que a patologia é geradora de amnésia irreversível e não de simples instabilidade da memória ${ }^{185}$.

A hipótese em que a prova não pode ser repetida em razão do desaparecimento (“irreperibilità") inesperado do depoente relaciona-se à ausência juridicamente reconhecida, de vítima ou testemunha, como aquela discriminada no artigo 22 do Código Civil brasileiro: "Desaparecendo uma pessoa do seu domicilio sem dela haver notícia, se não houver deixado representante ou procurador a quem caiba administrar-lhe os bens, o juiz, a requerimento de qualquer interessado ou do Ministério Público, declarará a ausência, e nomear-lhe-á curador".

À irreperibilità foram equiparadas duas outras situações, contempladas pelo legislador: a primeira, descrita no artigo 512 bis do Código de Processo Penal ${ }^{186}$, relaciona-se a casos de vítimas ou testemunhas residentes no estrangeiro que, citadas, não comparecem à audiência. A segunda, acolhida pelo artigo 513, inciso 2, segunda parte da mesma lei ${ }^{187}$, refere-se à impossibilidade de localização do réu acusador, que subtraiu-se ao dever de depor como testemunha no julgamento. Cabem sobre o assunto algumas considerações.

A irreperibilità pode dar causa à impossibilidade superveniente de repetição da prova somente quando tiver havido uma investigação, conduzida com rigor, com a finalidade de localizar a pessoa desaparecida. Deve-se possibilitar a utilização de todos os meios investigativos legalmente autorizados para encontrar-se a pessoa desaparecida, como buscas e inspeções. Segundo o artigo 513, inciso 2 (primeira parte) do Código de Processo Penal, deve-se tentar obter a presença do declarante no julgamento, mesmo que coercitivamente, ou, sendo ela impraticável, deve-se proceder ao exame em domicílio, à

\footnotetext{
185 "La semplice 'labilità di memoria' non sembra poter integrare il pressupposto della impossibilità di repetizione" (...) "l'amnesia è, invece, dovuta a cause patologiche, di cui sai accertata la sopravvenienza, si può considerare integrata la condizione della irrepetibilità determinata da fattori oggetive" (...) "l'amnesia, come inabilita a deporre non solo debba dispendere da cause patologiche, ma debba apparire 'irreversibille' e dimostrabile 'sulla base di certificati Médici o equipollenti'. In: DI MARTINO, Corrada; PROCACCIANTI, Teresa. La prova...op. cit., p. 370.

${ }^{186}$ Artigo 512bis: "O juiz, a pedido da parte, pode autorizar, levando em consideração outros elementos de prova adquiridos, que se dê a leitura do verbale das declarações feitas por pessoa residente no estrangeiro, mesmo que resultantes de rogatória internacional se essa, tendo sido citada, não compareceu e somente no caso de ser absolutamente impossivel seu exame na audiência de julgamento" (Tradução livre).

${ }^{187}$ Artigo 513, inciso 2, segunda parte: "Se não for possivel obter a presença do declarante, nem proceder ao exame de nenhum modo, aplicar-se-á a disposição do artigo 512, contanto que a impossibilidade dependa de fato imprevisível ao momento da declaração".
} 
rogatória internacional ou outros modos previstos pela lei para assegurar o contraditório na formação da prova. Apenas quando todos os esforços restarem infrutíferos é que se anuncia a irreperibilità do declarante (vítima, testemunha ou réu acusador) e autoriza-se a leitura da anterior declaração.

Por meio da decisão da Corte de Cassação italiana ${ }^{188}$ de $\mathrm{n}^{\mathrm{o}} 27918^{189}$, de 14 julho de 2011 , assentou-se o entendimento de que a mera impossibilidade jurídica de condução coercitiva de testemunha residente em outro país (que citada regularmente através de cooperação jurídica internacional não comparece à audiência) não pode ser entendida como uma objetiva impossibilidade de repetição. Esta, na visão da Corte, somente ocorre após exauridos os meios legais existentes para sua execução, como, por exemplo, a tentativa de tomada do respectivo depoimento pela via da carta rogatória internacional.

Segundo a Corte, a objetiva impossibilidade de repetição deve ser aferida num plano mais profundo, não pela simples verificação protocolar e rotineira de que houve uma citação regular da testemunha ausente. Trata-se da obrigação do juiz de fazer tudo quanto for possível para garantir a repetição das declarações. Ainda conforme a decisão, a impossibilidade de repetição da declaração deve referir-se a evento que independa da vontade da testemunha e estar de acordo com o que proclama o artigo $4^{\circ}$ da Convenção Europeia de Assistência Judiciária em matéria penal (segundo o qual, havendo o consentimento da autoridade requerida, a autoridade requerente e as partes processuais podem participar do ato de execução da carta rogatória. A colaboração, segundo a Corte, visa o fortalecimento do sistema acusatório ${ }^{190}$ ) e o artigo 14, inciso 3, alínea $e$ do Pacto Internacional sobre Direitos Civis e Políticos (pelo qual as decisões condenatórias não

\footnotetext{
${ }^{188}$ A Corte de Cassação italiana é responsável por assegurar a homogeneidade de interpretação das normas em todo o território do país. Está acima da Corte Constitucional italiana (responsável pela análise da legalidade das normas ordinárias à luz do texto constitucional). Não há, no Brasil, órgão com funções exatamente iguais às da Corte de Cassação, mas pode-se dizer que o Supremo Tribunal Federal brasileiro mescla funções das duas Cortes italianas (Constitucional e de Cassação).

${ }_{189}$ Disponível em http://www.cortedicassazione.it/Documenti/Relazione\%20104_11.pdf e http://www.cortedicassazione.it/Notizie/GiurisprudenzaPenale/SezioniUnite/SchedaNews.asp? ID=1703, acesso em 20/11/2011.

${ }^{190}$ Artigo 4: "Se la Parte richiedente ne fa domanda espressa, la Parte richiesta l'informerà della data e del luogo d'esecuzione della commissione rogatoria. Le autorità e le persone in causa potranno assistere all'esecuzione se la Parte richiesta vi acconsente".
} 
podem basear-se exclusiva ou preponderantemente em declarações feitas por pessoas que o acusado não foi capaz de examinar pessoalmente ${ }^{191}$ ).

No tocante à possibilidade de utilização de documentação (verbale) de atos não repetíveis de outros processos, autoriza-a a lei ${ }^{192}$. Mas, diferentemente do que se exige para as provas emprestadas repetíveis e naturalmente irrepetíveis, a prova emprestada de irrepetibilidade superveniente é aceita mesmo que o réu ou seu defensor não tenham participado do ato de produção original da prova.

De um modo geral, as provas de irrepetibilidade superveniente suscitam debates e recebem críticas da doutrina italiana, pois, pelo simples fato de ser impossível a previsão do evento modificativo ou extintivo da fonte de prova, admite-se sua utilização para formar o convencimento do julgador. Note-se que as provas de irrepetibilidade superveniente não são submetidas à contradita das partes (em razão da impossibilidade de examinar-se a fonte de prova, inexistente ao tempo do julgamento), diferentemente das provas de irrepetibilidade natural, para as quais há possibilidade de realização de contraditório, concomitante ou diferido, mas sempre eficaz.

De acordo com GRIFANTINI, "l'uso delle dichiarazioni anteriori al dibattimento per oggetiva impossibilità di ripetizione è incompatibile com il diritto della difesa di examinarne la fonte in contradittorio, garantito dall'art. 6, par. 3 Conv. Europea, Nei casi in cui la condanna dell'imputato si fondi esclusivamente o in misura determinante su di esse: cioè quando la dichiarazione scritta risulti decisiva e, a maggior ragione, quando formi l'única prova a suo carico"193. No mesmo sentido, UBERTIS: "Né potrebbe poi mancarsi di evidenziare l'iggettimità constituzionale degli art. 238, comma 3, 512 e 512bis, cpp, almeno in quanto riferiti a elementi di prova dichiarativi" ${ }^{194}$.

\footnotetext{
${ }^{191}$ Artigo 14, inciso 3: "Ogni individuo accusato di un reato ha diritto, in posizione di piena eguaglianza, come minimo, alle seguenti garanzie: e. a interrogare o far interrogare i testimoni a carico e ad ottenere la citazione e l'interrogatorio dei testimoni a discarico nelle stesse condizioni dei testimoni a carico".

${ }^{192}$ Artigo 238, inciso 3: “E' comunque ammessa l'acquisizione della documentazione di atti che non sono ripetibili. Se la ripetizione dell'atto è divenuta impossibile per fatti o circostanze sopravvenuti, l'acquisizione è ammessa se si tratta di fatti o circostanze imprevedibili”.

${ }^{193}$ In: GRIFANTINI, F.M., Utilizzabilità in dibattimento di atti provenienti dalle fasi anteriori, in: La prova nel dibattimento penale, Torino: Giappichelli, 2007, p. 239.

${ }^{194}$ In: UBERTIS, Giulio. Il contraddittorio nella formazione della prova penale. In: YARSHELL, Flávio Luis; MORAES, Maurício Zanoide (Org.). Estudos em homenagem ... op. cit., p. 339.
} 
O ponto mais discutido por doutrinadores, italianos e brasileiros, relaciona-se à possibilidade de que uma de prova de irrepetibilidade superveniente possa (ou não), isoladamente, amparar o decreto condenatório ${ }^{195}$.

Tanto o artigo 155 do Código de Processo Penal brasileiro como o artigo 512 do Código de Processo Penal italiano possibilitam a interpretação de que as provas de irrepetibilidade superveniente podem ser usadas exclusivamente para a condenação. Essa interpretação foi, aliás, adotada por anos pela Corte Constitucional italiana.

Houve, no entanto, alteração do paradigma vigente, quando, por meio da sentença $\mathrm{n}^{\mathbf{o}}$ 44158, de 23 de setembro de 2009, e da sentença ${ }^{\circ} 27582$, de 15 de junho de 2010, a Corte de Cassação italiana assentou o entendimento de que as provas de irrepetibilidade superveniente podem ser usadas na formação do convencimento do julgador, mas somente se estiverem amparadas por elementos de prova produzidos em contraditório judicial ${ }^{196}$.

195 “O ponto mais discutido em outros países é a delimitação do valor probatório de atos irrepetíveis por fato posterior, como ocorre no caso de uma testemunha que venha a falecer, desaparecer, mudar do país. $E^{\prime}$ normalmente aceito o depoimento, se ficar evidenciado o fato superveniente. Todavia, sem tal demonstração, não se admite atribuir valor probatório às declarações da testemunha não inquirida em contraditório

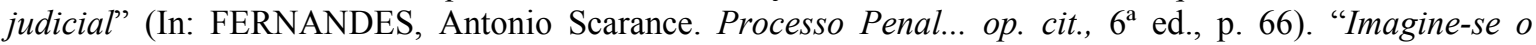
absurdo: toda prova se resume nos depoimentos, colhidos na investigação policial, da vítima e de duas testemunhas que faleceram antes de poderem ser ouvidas em juizo. Seus depoimentos não podem ser repetidos, logo a condenação poderia basear-se exclusivamente neles?" (In: GRECO FILHO, Vicente. Manual de ...op. cit., p. 204-205).

${ }^{196}$ A orientação normativa foi publicada no anuário de jurisprudência da Corte de Cassação (p. 17-19), em 2010, nos seguintes termos: "In relazione al regime delle letture ed al tema della valutazione della prova testimoniale conseguentemente acquisita, va registrata la netta affermazione che la dichiarazione accusatoria della persona offesa acquisita ai sensi dell'art. $512 \mathrm{cod}$. proc. pen. deve trovare conforto, per sostenere l'accusa, in ulteriori elementi individuati dal giudice, con doverosa disamina critica, nelle risultanze processuali. Premesso che la previsione dell'ipotesi di formazione della prova senza contraddittorio ammessa dall'art. 111, comma quinto, della Costituzione <<per accertata impossibilità di natura oggettiva $>>$ va intesa nel senso che essa "deve essere ammessa, pur in presenza di volontario allontanamento del denunciante, quando poi ne risulti oggettivamente impossibile il rintraccio, il rientro o la escussione", poiché il criterio rilevante ai fini dell'interpretazione della disposizione di cui all'art. 526, comma 1-bis, cod. proc. pen. è quello della <<rimproverabilità >> del soggetto da escutere, in relazione all' $<<$ essersi volontariamente sottratto all'esame da parte dell'imputato $>>$, e non al semplice allontanamento volontario per altri motivi ("come si desume dalla circostanza che tale rimproverabilità è stata esclusa quando è mancato l'atto della citazione a giudizio del teste”), si è evidenziato che le dichiarazioni in tal modo acquisite non sfuggono "al necessario vaglio sull'attendibilità soggettiva ed oggettiva che sempre $\grave{e}$ posto a carico del giudice del merito ma che, nel caso di specie, lo è con richiesta di massimi oculatezza e rigore, in ragione della peculiare natura delle dichiarazioni stesse, non dovendosi dimenticare che esse sono state pur sempre acquisite in assenza di contraddittorio, da una sola delle parti deputate alla ricerca degli elementi utili al processo. A tale conclusione porta, del resto, anche la giurisprudenza della Corte EDU la quale, nell'interpretare l'art. 6 della Convenzione EDU, ha formulato principi nei quali il giudice nazionale, nei limiti del portato normativo delle leggi statali, deve-nella ricorrenza dei relativi presupposti 
A Corte entendeu que a regra disposta no artigo 526, inciso 1-bis do Código de Processo Penal (que diz que o acusado não poderá ser condenado com base em declarações feitas por quem livremente subtraiu-se ao exame cruzado com ele ou com seu defensor) deve ser interpretada ampliativamente, no sentido de que a condenação não pode basear-se principalmente na declaração feita por quem não foi submetido ao exame cruzado com o acusado e seu defensor.

Com a interpretação proposta, a Corte de Cassação buscou um alinhamento entre o devido processo penal italiano (pelo qual se permite a utilização de provas não produzidas em contraditório quando presentes uma das exceções constitucionais do artigo 111, inciso 5 da Constituição do país) e o devido processo legal estabelecido no artigo $6^{\circ}$ da convenção da Corte Europeia de Direitos do Homem (cuja interpretação leva ao entendimento de que nenhuma condenação será sustentada em prova que não tiver sido submetida ao contraditório com o acusado).

- tendere ad inquadrare, ed ai quali deve uniformare, i precetti cui è chiamato a dare applicazione, altrimenti esponendo $i$ precetti stessi al sospetto di incostituzionalità per contrasto con gli obblighi internazionali (art. 117 Cost.)" (...) "Alle medesime conclusioni, e per le medesime ragioni, è giunta anche altra decisione, per la quale "una sentenza di condanna che si fonda sulle sole dichiarazioni rese dai testi fuori del contraddittorio con la difesa ed acquisite a norma dell'art. 512 c.p.p., è in sintonia con i principi desumibili dal nostro assetto costituzionale, ma non con quelli derivanti dalla Convenzione EDU”. Si è in proposito evidenziato che il sistema normativo risultante dagli artt. 526, comma 1-bis, cod. proc. pen. (che riproduce in parte qua l'art. 111 Cost.) e dall'art. 111, comma quinto, Cost. "non è stato ritenuto conforme all'art. 6 della Convezione EDU dai Giudici di Strasburgo che hanno in più occasioni affermato che l'impossibilità di reiterare un atto compiuto nel corso delle indagini preliminari non può privare l'imputato del diritto di esaminare o fare esaminare ogni elemento di prova decisivo a suo carico; le emergenze accusatorie sorte fuori del contraddittorio non sono inutilizzabili in assoluto, ma possono essere usate a condizione che non si attribuisca ad esse un peso determinante ai fini della decisione. Secondo la Corte di Strasburgo, $i$ diritti dell'imputato sono limitati in modo incompatibile con le garanzie della Convenzione quando una condanna si basi, unicamente o in misura preponderante, su deposizioni rese da persone che l'imputato non ha potuto interrogare o fare interrogare né nella fase delle indagini né in quella dibattimentale. Al Giudice nazionale incombe l'obbligo di dare, se possibile, alle norme interne una interpretazione conforme ai precetti della Convenzione EDU nella esegesi giudiziale istituzionalmente attribuita alla Corte di Strasburgo dall'art. 32 della Convenzione stessa. Di conseguenza, si deve rilevare che una interpretazione dell'art. 512 c.p.p. convenzionalmente orientata porta a concludere che al principio del contraddittorio si può derogare, in caso vi sia una oggettiva impossibilità di formazione della prova, con la precisazione che una declaratoria di condanna non può reggersi in modo esclusivo o significativo su dichiarazioni di chi si sia sottratto al confronto con l'imputato". Disponível em http://www.cortedicassazione.it/Documenti/Giurisprudenza\%20penale\%20e\%20civile\%202010.pdf, acesso em 10 de fevereiro de 2012. 
Em resumo, houve o estreitamento da aplicação da norma constitucional italiana (na medida em que as provas irrepetíveis podem ser usadas, mas não exclusivamente, como pretendia o legislador) e o alargamento da interpretação da regra do contraditório estabelecida na convenção da Corte Europeia (na medida em que o artigo $6^{\circ}$, que prevê a obrigatoriedade do contraditório na formação da prova, foi flexibilizado, permitindo-se a utilização de prova irrepetível na Itália, mas exclusivamente de modo subsidiário aos elementos de prova produzidos em contraditório judicial).

No Brasil também despontam entendimentos de que, para ser aceita, a prova irrepetível deve encontrar apoio em outros elementos de prova formados em contraditório judicial ${ }^{197}$. No entanto, a posição não é unânime ${ }^{198}$.

197 "Resta a prova não repetivel. Quanto a esta, exemplificando com a testemunha falecida ou que não é encontrada para depor em juizo, de duas uma: ou seu depoimento está corroborado por provas submetidas a contraditório (prévio, concomitante ou diferido) ou não está. Se está, pode, e isso sempre foi possível, compor o conjunto probatório suficiente para a condenação; se não está, exclusivamente não pode servir de base para a condenação e não há disposição legal que possa fazê-lo valer em virtude do princípio constitucional do contraditório" (In: GRECO FILHO, Vicente. Manual de ...op. cit., p. 204-205). "Realmente, pensemos nas provas não repetiveis. Poderia o magistrado se basear apenas e exclusivamente nela para proferir um decreto condenatório? Entendemos que não. O simples fato de uma prova ter sido produzida no inquérito policial e ter se tornado impossível a sua repetição em juízo (prova produzida no inquérito + ser irrepetível) não pode justificar, a nosso ver, uma exceção ao princípio do contraditório. Suponhamos o exemplo de uma única testemunha presencial de um latrocínio que foi ouvida durante o inquérito, mas que falece antes do início da instrução processual. Neste caso, entendemos que o juiz não poderá considerar isoladamente esta prova para fins de condenação, pois o contraditório não estaria sendo observado, seja no momento da produção da prova (contraditório real), seja posteriormente (contraditório diferido). Como contraditar esta testemunha, como fazer perguntas, como verificar se não foi pressionada para que assinasse seu termo de depoimento? Neste ponto, caso o magistrado considerasse essa prova exclusivamente para embasar a condenação, estaríamos diante de uma lesão frontal, segundo pensamos, ao princípio do contraditório. Não teria sentido em considerar que a mera impossibilidade de repetição pudesse transmudar essa prova de "não apta" para "apta” a fundamentar um decreto condenatório" (In: MENDONÇA, Andrey Borges de. Os Elementos Produzidos Durante o Inquérito e as Provas Antecipadas, Cautelares e Irrepetíveis, segundo a Reforma do CPP. In: Reforma Processual Penal. Revista ESMP, Ano 1 Volume 2, $\mathrm{n}^{\circ}$ 1, julho/dezembro 2008. p. 86). "Prova emprestada produzida sob o crivo do contraditório e advinda de processo em que os apelados restaram condenados é irrepetivel e deve, portanto, ser acolhida, em não sendo a única nos autos a aclarar a autoria (Precedentes desta Corte, do STJ e STF)" (TRF4, ACR 200671050008207, TADAAQUI HIROSE, 04/06/2010).

198 (...) "a nova redação do art. 155 do Código de Processo Penal, invocada pela própria defesa, é clara ao preceituar que 'o juiz formará sua convicção pela livre apreciação da prova produzida em contraditório judicial, não podendo fundamentar sua decisão exclusivamente nos elementos informativos colhidos na investigação, ressalvadas as provas cautelares, não repetíveis e antecipadas' (sublinhei). Logo, tendo o ofendido falecido, seu depoimento policial, por se tratar de uma prova não repetível, tem o condão de sustentar, ainda que isoladamente, a decisão de pronúncia." (Recurso em Sentido Estrito n ${ }^{\circ} 70042755124$, TJRS, $1^{\text {a }}$ Câmara Criminal, Comarca de São Francisco de Paula, Relator Des. Marco Antônio Ribeiro de Oliveira, julgado em 28/09/2011). 


\section{Reflexões finais sobre a aplicabilidade das regras italianas ao direito brasileiro e proposta de alteração legislativa}

Com o texto alçado ao artigo 155 do Código de Processo Penal no anteprojeto sobre provas, em 2002, intencionava-se impedir o uso de elementos informativos na formação do convencimento do julgador. Temia-se, naquela época, o que ainda hoje se receia ${ }^{199}$ : que a utilização de provas do inquérito leve a situações de desrespeito aos direitos e garantias constitucionalmente assegurados.

Concordamos que a regra de inutilizabilidade total das informações contidas no inquérito assegura, da forma mais eficiente possível, os direitos do acusado. No entanto, ao analisarmos a situação ocorrida na Itália, no final da década de 1980 e começo da década de $1990^{200}$, verificamos que a adoção de um regramento rígido, que impeça por completo o uso de informações adquiridas nas investigações, também pode conduzir a injustiças.

Esta situação traduz uma das discussões mais relevantes do processo penal na atualidade. A busca pelo equilíbrio entre eficiência e garantismo, pela qual se deve perquirir a eficiência do processo criminal, enquanto método de justiça, mediante o asseguramento das garantias constitucionais aos acusados.

O problema é delicado e de difícil solução, mas nos parece que o equilíbrio idealmente perquirido pode ser obtido se o ordenamento jurídico for composto por regras que integrem valores caros aos indivíduos e à sociedade que os acomoda. Sob esta ótica, entendemos que a utilização de informações do inquérito deve ser possibilitada em determinadas situações (que visem o equilíbrio almejado), a serem previstas na lei, de modo detalhado.

\footnotetext{
${ }^{199}$ Atualmente o Projeto de Lei n ${ }^{\circ} 156 / 2009$, relativo à criação de um novo Código de Processo Penal (que tramita atualmente na Câmara dos Deputados sob o $\mathrm{n}^{\circ}$ 8045/10) prevê a criação do denominado juiz das garantias, pelo qual se busca dissociar as funções judiciais exercidas na etapa do inquérito daquelas relacionadas ao processo propriamente dito. Seu objetivo é, assim, o de resguardar o juiz da causa do contato indesejado com a prova produzida na etapa policial.

${ }^{200}$ Trata-se do período que sucedeu a implantação do princípio da oralidade, de forma absoluta, no Código de Processo Penal italiano. Neste momento, Justiça e sociedade viram-se reféns da criminalidade organizada, que utilizava o poder econômico para assassinar testemunhas ou suborná-las, a fim de que não depusessem em juízo. A rigidez legal que impedia a utilização dos elementos informativos das investigações tornou-se o mecanismo que impossibilitava a identificação da responsabilidade criminal de agentes perigosos. Os problemas vivenciados pela sociedade da época refletiram a promulgação de leis severas que trouxeram outros graves problemas à sociedade.
} 
Em nosso sentir, a atual redação do artigo $155^{201}$ do Código de Processo Penal permite o uso indiscriminado das provas produzidas na etapa das investigações, na medida em que dá margem à interpretação de que poderiam servir, exclusivamente, ao embasamento de sentença criminal.

Pensamos que a condenação não pode ser lastreada exclusivamente em prova sobre a qual o contraditório não possa ser exercido em seu grau máximo. Em outros termos, a sentença condenatória não pode ter como fundamento principal uma prova produzida durante as investigações, sem que se possibilite a participação do réu, em contraditório concomitante. Esta também foi a interpretação da Corte de Cassação italiana sobre artigo 512 do Código de Processo Penal (nas sentenças nº 44158 e n 27582).

O contraditório é o mecanismo que possibilita às partes a interferência (entenda-se, benéfica) na formação do convencimento do julgador. É por meio dele que defesa e acusação imbuem no espírito do julgador a verdade processualmente válida. Se pelo contraditório não houver a possibilidade de alteração do animus do julgador, a garantia será um mero protocolo tendente a emprestar validade formal ao ato de produção da prova. Não será eficiente e nem representará a vontade do legislador, que viu nele o instrumento que viabiliza ao acusado interagir no processo de sua condenação e, eventualmente, revertê-lo.

Assim, o que se deve ter em mente é que as provas produzidas na etapa do inquérito (sejam elas repetíveis ou irrepetíveis) não devem ser utilizadas pelo julgador se não puderem ser submetidas a um contraditório eficiente. Essa é a análise que deve guiar a aferição da legitimidade constitucional das provas produzidas no inquérito. Nota-se, contudo, que a ausência de uma regulamentação normativa eficiente, a dificulta.

Entendemos que a regulamentação legal almejada deve ser inspirada na experiência italiana, fruto da produção legislativa sobre o tema e das interpretações dela, feitas pela

\footnotetext{
201 “O juiz formará sua convicção pela livre apreciação da prova produzida em contraditório judicial, não podendo fundamentar sua decisão exclusivamente nos elementos informativos colhidos na investigação, ressalvadas as provas cautelares, não repetíveis e antecipadas".
} 
Corte de Cassação (que nos últimos anos, por meio da expedição de jurisprudência vinculativa, atenuou o rigor de algumas normas polêmicas, expedidas pelo legislador no início dos anos 1990). E deve refletir os anseios da sociedade e as garantias constitucionais asseguradas no Brasil.

Sob esse enfoque, podemos sugerir que o artigo 155 do Código de Processo seja assim reescrito:

“Artigo 155. Das provas utilizáveis ao final dos debates.

Caput. O livre convencimento do julgador deve fundamentar-se preponderantemente em provas produzidas em contraditório judicial.

$\S 1^{\circ}$. Admite-se o uso de provas produzidas cautelarmente durante as investigações. Somente em razão de comprovada urgência será afastado o direito de participação dos interessados no ato de produção da prova, hipótese em que sua validade ficará condicionada ao contraditório diferido.

$\S 2^{\circ}$. Admite-se o uso de documentos, quando submetidos a contraditório depois de seu ingresso nos autos do processo.

$\S 3^{\circ}$. A culpabilidade não pode ser baseada em declarações feitas por quem não foi submetido ao exame cruzado com o réu ou seu defensor. Entretanto, as declarações prestadas na etapa do inquérito podem ser utilizadas nas seguintes hipóteses:

Inciso 1. Em beneficio do acusado, quando, por livre vontade, o declarante negar-se ao exame cruzado em audiência, com ele ou seu defensor.

Inciso 2. Para o confronto de informações apresentadas pelo réu ou declarante, quando divergentes, com o fim de firmar a respectiva credibilidade. Persistindo a divergência, é vedado ao julgador formar seu convencimento com base na declaração tomada extrajudicialmente, levando-se a dúvida, à absolvição.

Inciso 3. Sempre que a impossibilidade de formação da prova em contraditório judicial decorrer de comprovada conduta ilícita do acusado, assim entendida a ameaça, a violência, o suborno ou o oferecimento de vantagem, será permitido o uso das declarações precedentes, de forma subsidiária.

Inciso 4. Quando, por circunstâncias objetivas e imprevisiveis, tornou-se impossivel a declaração em audiência, será permitido o uso das declarações precedentes, de forma subsidiária.

$\S 4^{\circ}$. O réu tem resguardado o direito ao silêncio. No entanto, ao declarar em prejuizo de corréus, assume a qualidade de testemunha com relação aos fatos que lhes imputem responsabilidade criminal. $O$ dever de testemunhar não pode, entretanto, sobrepor-se ao direito do réu à não autoincriminação. 
$\S 5^{\circ}$. A utilização de provas produzidas contra o acusado, em outros processos, é consentida, se no feito original teve ele a possibilidade de exercer seu direito ao contraditório.

$\S 6^{\circ}$. Fora dos casos previstos neste artigo, as provas produzidas na etapa das investigações podem ser utilizadas sempre que houver consentimento das partes”.

Note-se que optamos por desvencilhar da norma a terminologia utilizada pelo legislador na redação do atual artigo 155 (elementos informativos, provas cautelares, antecipadas e não repetíveis). Como dissemos no Capítulo II, os termos utilizados têm conceitos não estanques e podem gerar dubiedade e conflitos interpretativos.

Com a redação proposta, evitam-se dúvidas quanto às diferenças entre provas cautelares e antecipadas (tratadas conjuntamente como "provas produzidas cautelarmente" no $\S 1^{\circ}$ ) $\mathrm{e}$ fica clara a distinção operada entre elas (provas naturalmente repetíveis) e as provas de irrepetibilidade superveniente (tratadas no inciso $4^{\circ}$ e cuja possibilidade de utilização é estritamente subsidiária).

Também resta clara a possibilidade de leitura contestatória (sobre as provas repetíveis perfeitas, no inciso $2^{\circ}$ ) e de utilização de provas repetíveis imperfeitas (que pode ser exclusiva, na hipótese do inciso $1^{\circ}$, e apenas subsidiária, na hipótese do inciso $3^{\circ}$ ).

É importante dizer que a redação proposta fixa diretrizes ao convencimento do julgador e enfatiza que a motivação da sentença deve ser feita preponderantemente sobre provas produzidas em contraditório judicial (o que implica na impossibilidade de utilização exclusiva do material do inquérito). Mas ressaltamos que, além de o julgador ter por dever seguir normas (como as que sugerimos) que regulamentem seu uso, a legitimidade constitucional das provas repetíveis e irrepetíveis (integradas ao inquérito, que ingressa no processo por ocasião da denúncia), é assunto que deve ser debatido entre as partes, antes da audiência. 
Aliás, no que respeita o ingresso do inquérito no processo, assunto que sempre foi objeto de discussões doutrinárias e jurisprudenciais ${ }^{202}$, entendemos que a cisão física dos autos favoreceria a almejada imparcialidade do julgador. Todavia, em nosso sentir, mais importante que o contato do juiz com os autos do inquérito, é a existência de regras bem delimitadas que regulamentem o uso das provas não produzidas em contraditório judicial.

Isso resta claro quando nos deparamos com a sistemática do direito italiano: nesse ordenamento jurídico, o material do inquérito permanece em um arquivo separado (pertencente ao Ministério Público) daquele que contém as provas que serão usadas no julgamento. Entretanto, algumas das regras que regulamentam o uso do material probatório das investigações são amplas a ponto de permitirem a utilização exclusiva de provas não contraditadas pelas partes ${ }^{203}$ - hipótese que esvazia de sentido a preocupação com a cisão entre inquérito e processo.

\footnotetext{
${ }^{202}$ De acordo com Lopes Jr, o problema nasce no momento em que o inquérito acompanha e integra os autos do processo e passa a ser valorado na sentença, ainda que sob a fórmula de 'cotejado com a prova judicial'. In: LOPES JUNIOR, Aury. Sistemas de ...op. cit., $4^{a}$ ed., p. 186.

${ }^{203}$ Como, por exemplo, a regra do artigo 512 do Código de Processo Penal, que em sua interpretação literal admite o uso de prova de irrepetibilidade superveniente de forma exclusiva (e não subsidiária). Relembramos que o artigo foi objeto de análise pela Corte de Cassação, que formou jurisprudência no sentido de ser subsidiário o uso de tais provas.
} 


\section{CONCLUSÕES}

Em 2008 houve a implantação da atual redação do artigo 155 do Código de Processo Penal, por meio da qual se legitimou o uso de provas produzidas na etapa das investigações, entre as quais se incluem as provas não repetíveis. O legislador não atribuiu significado das provas às quais fez referência, tampouco teceu esclarecimentos a respeito do modo como elas seriam compatibilizadas com a garantia do contraditório.

Foram objetivos principais de nosso estudo (i) clarificar o conceito de provas não repetíveis; (ii) analisar a interação do conceito de provas não repetíveis com outras provas produzidas durante as investigações; (iii) alcançar a compreensão do tratamento normativo e doutrinário das provas não repetíveis nos processos penais brasileiro e italiano; e (iv) refletir, à luz da das regras estabelecidas na Constituição Brasileira, se a regulamentação italiana sobre as provas não repetíveis teria aplicação no processo penal brasileiro. Depois de realizadas tais aferições, confirmamos a necessidade de reformulação do artigo 155, o que nos levou à proposição de um novo texto normativo.

Para tanto, o trabalho foi dividido em três capítulos. O primeiro, sobre a teoria das provas, com o qual buscamos apresentar a terminologia geral associada às provas no processo penal e os princípios e regras constitucionais que, direta ou indiretamente, mantêm relação com o tema de nosso estudo.

No segundo capítulo tecemos considerações sobre a produção de provas durante as investigações, buscamos alcançar a compreensão dos conceitos aplicáveis aos fenômenos probatórios da fase investigativa (elementos informativos, provas não repetíveis, cautelares e antecipadas), realizamos a análise do artigo 155 do Código de Processo Penal e propusemos uma sistematização terminológica para facilitar o estudo sobre a irrepetibilidade probatória. 
No capítulo terceiro, com base na sistematização sugerida, apontamos o tratamento dado na Itália às provas produzidas em fases anteriores do processo, abordamos os aspectos relevantes e a problematização relacionada ao estudo; procuramos estabelecer parâmetros de aceitabilidade das regras italianas no processo penal brasileiro; por fim, as conclusões obtidas nos levaram a sugerir uma nova redação ao artigo 155 do Código de Processo Penal, baseada no regramento italiano, com a finalidade de delimitar as hipóteses de uso das provas produzidas na etapa investigativa.

Buscamos pontuar, no decorrer do trabalho, conclusões sobre os temas colocados em discussão. De modo geral, as principais conclusões alcançadas podem ser assim sintetizadas:

1. Ao redigir o artigo 155 do Código de Processo Penal o legislador congregou elementos informativos, provas cautelares, provas antecipadas e provas não repetíveis como fenômenos probatórios da etapa investigativa. Não lhes atribuiu, todavia, significado.

2. Propusemos, então, a aplicação da seguinte terminologia: (i) irrepetível é a prova cuja fonte (pessoa ou objeto) não puder ser submetida a exame na audiência de julgamento, em razão de alteração significativa das características que lhe são peculiares, ou de sua extinção; (ii) elementos informativos são os dados coletados durante as investigações com o escopo primário de fornecer ao órgão acusador as informações necessárias à propositora da ação penal, ou ao seu arquivamento. Sua função residual é a de dar suporte à decretação de prisões e outras medidas restritivas de direito; (iii) provas cautelares (stricto sensu) e provas antecipadas são espécies do mesmo gênero (provas cautelares lato sensu), mas enquanto as primeiras (cautelares stricto sensu) servem à obtenção de fontes de prova, as segundas (provas antecipadas) servem à obtenção de elementos de prova.

3. Observamos que as provas não repetíveis foram tratadas no artigo 155 do Código de Processo Penal como um instituto estanque dos demais (elementos informativos, provas cautelares e antecipadas). Mas doutrina e jurisprudência apontam a convergência dos termos em determinados pontos. Para o esclarecimento da questão antevimos a necessidade de que o estudo sobre a irrepetibilidade probatória fosse alargado (ou seja, não limitado às 
provas irrepetíveis, mas voltado a identificar, no conjunto de provas - repetíveis e não repetíveis - aquelas que podem ser usadas na motivação da sentença criminal). Propusemos, então, sistematizar o estudo. Os elementos informativos e os elementos de prova foram separados em categorias (provas repetíveis perfeitas, provas repetíveis imperfeitas, provas naturalmente irrepetíveis e provas de irrepetibilidade superveniente), de acordo com a possibilidade de a fonte de prova ser repetida no julgamento. Na divisão proposta, levamos em conta as razões da (im)possibilidade da repetição da prova e as consequências processuais dela advindas. A classificação possibilitou-nos compreender as o tratamento das hipóteses na Itália e analisar sua aplicabilidade no processo penal brasileiro.

4. Identificamos que há interação entre o conceito das provas não repetíveis com o de outras provas produzidas durante as investigações. As provas naturalmente irrepetíveis têm relação direta com as provas cautelares (em sentido estrito) e antecipadas; as demais provas (repetíveis perfeitas e imperfeitas, e provas de irrepetibilidade superveniente) têm relação direta com os elementos de prova produzidos nas investigações. E analisamos as consequências práticas disso, por meio das quais chegamos às conclusões expostas abaixo.

5. A prova repetível (aquela cuja fonte mantém-se íntegra, vale dizer, tal qual o era à época do crime, até a audiência de julgamento) será perfeita quando produzida no julgamento, e imperfeita quando não produzida no julgamento por razão atribuível à vontade humana (quer da testemunha, que consciente e voluntariamente subtrai-se aos respectivos deveres processuais, quer do réu, que lança mão de ameaça, violência ou suborno para influenciá-la a deixar de declarar em juízo).

6. O elemento informativo, advindo da prova repetível perfeita, pode ser usado unicamente para firmar a credibilidade do depoente, que em juízo apresenta versão distinta daquela apresentada na fase do inquérito. Trata-se da denominada leitura contestatória, que pode retirar o valor da declaração feita no julgamento, mas não pode servir à formação do convencimento do julgador. Aferimos que no Brasil o confronto das declarações leva à possibilidade de uso dos elementos informativos do inquérito no convencimento do julgador e que ele deve ser coibido pelas razões expostas no Capítulo III. 
7. O elemento informativo, advindo da prova repetível imperfeita, pode servir como prova desfavorável ao réu quando este agir ilicitamente, impedindo nova produção da prova em juízo. E pode servir como prova favorável ao réu quando a testemunha agir ilicitamente, deixando de depor ou de submeter-se ao exame cruzado, impossibilitando ao réu comprovar sua inocência. Entendemos que o instituto deve ser aplicado ao processo penal brasileiro, contanto que se estabeleçam regras no sentido de que o uso de elementos informativos deve ser subsidiário.

8. A prova naturalmente irrepetível é aquela cuja fonte (pessoa ou objeto) não pode ser submetida a exame na audiência de julgamento, em razão de alteração significativa das características que lhe são peculiares, ou de sua extinção. Ela é aceita no ordenamento jurídico italiano, e serve à formação do convencimento do julgador de duas formas: (i) exclusivamente, quando sua produção ocorrer pela via do incidente probatório de antecipação de prova (que garante o contraditório concomitante entre as partes); (ii) e subsidiariamente, quando não houver o uso de incidente probatório (cuja obrigatoriedade somente é afastada quando a produção da prova não puder ser postergada, sem que disso decorra a perda ou extinção da fonte de prova) e o contraditório for diferido. Entendemos que as regras italianas sobre provas naturalmente irrepetíveis têm plena aplicabilidade no processo brasileiro.

9. A prova de irrepetibilidade superveniente liga-se à inesperada modificação ou extinção da fonte de prova. Dão causa à irrepetibilidade superveniente a morte, a enfermidade e o desaparecimento inesperados do declarante. Trata-se da hipótese que causa maior desconforto na comunidade jurídica, pois, segundo a interpretação literal da norma que lhe dá validade (artigo 512 do Código de Processo penal italiano), ela poderia ser usada exclusivamente na motivação da sentença. Atualmente há jurisprudência vinculante no sentido de que seu uso é subsidiário. Entendemos que as provas de irrepetibilidade superveniente podem ser aceitas no processo penal brasileiro, contanto que do modo como interpretou a Corte italiana (subsidiariamente, portanto). 
10. Concluímos, por fim, que a atual redação do artigo 155 do Código de Processo Penal dá margem à interpretação de que provas produzidas durante as investigações, sem a participação dos interessados, poderiam ser utilizadas exclusivamente no convencimento do julgador. E que em razão disso o artigo de lei é tocado por vício de inconstitucionalidade. Sugerimos, portanto, uma nova redação para a norma, inspirada nos pontos da legislação italiana (e de sua interpretação doutrinária e jurisprudencial) que possuem convergência com o texto constitucional brasileiro. 


\section{BIBLIOGRAFIA}

ALMEIDA, Canuto Mendes de. Princípios fundamentais do Processo Penal, São Paulo: Revista dos Tribunais, 1973.

ARANTES FILHO, Marcio Geraldo Britto. A interceptação de comunicações de pessoas presentes como meio de investigação de prova no direito processual penal. Dissertação de Mestrado defendida na Faculdade de Direito da Universidade de São Paulo em 2010.

. A disciplina da prova no Código de Processo Penal italiano, in: Provas no processo penal - estudo comparado. FERNANDES, Antonio Scarance; ALMEIDA, José Raul Gavião; MORAES, Maurício Zanoide (coords). São Paulo: Saraiva, 2011.

BADARÓ, Gustavo Henrique Righi Ivahy. Direito processual penal, tomo 1, Rio de Janeiro: Elsevier, 2008.

- Provas atípicas e provas anômalas: inadmissibilidade da substituição da prova testemunhal pela juntada de declarações escritas de quem poderia ser testemunha. In: YARSHELL, Flávio Luis; MORAES, Maurício Zanoide (Org.). Estudos em homenagem à professora Ada Pellegrini Grinover. $1^{\mathrm{a}}$ ed., São Paulo: DPJ, 2005.

; GOMES FILHO, Antonio Magalhães. Prova e sucedâneos de prova no processo

penal brasileiro. In: Revista Brasileira de Ciências Criminais, $\mathrm{n}^{\circ}$ 65, São Paulo: Editora Revista dos Tribunais, março-abril de 2007.

CAPEZ, Fernando. Curso de Processo Penal. $4^{\mathrm{a}}$ ed., São Paulo: Saraiva, 1999.

CESARI, C. Giusto processo, contraddittorio ed irrepetibilità degli atti d'indagine. In: Rivista italiana di diritto processuale penale, 2001, $\mathrm{n}^{\mathrm{o}} 75$. 
CHIAVARIO, Mario. Processo e garanzie della persona, $2^{\mathrm{a}}$ ed., volume 1, Milano: Giuffré, 1982.

. Diritto Processuale Penale, $4^{\mathrm{a}}$ ed., Milano: Utet Giuridica, 2010.

CINTRA, Antônio Carlos de Araújo; GRINOVER, Ada Pellegrini; DINAMARCO, Cândido Rangel. Teoria Geral do Processo, $22^{\mathrm{a}}$ ed. revisada e atualizada, São Paulo: Malheiros, 2006.

DAVID, René. 1906. Os grandes sistemas do direito contemporâneo (Les grands systèmesdu droit contemporains) - Tradução Hermínio A. Carvalho, $4^{\mathrm{a}}$ ed., São Paulo: Martins Fontes, 2002.

DE PLACIDO E SILVA. Vocabulário Jurídico, vol. 2, Rio de janeiro: Forense, 1963.

DEZEM. Guilherme Madeira. Da prova penal: tipo processual, provas típicas e atípicas atualizado de acordo com as Leis 11.689/08, 11.690/08 e 11.719/08. Campinas: Millenium, 2008.

DI MARTINO, Corrada; PROCACCIANTI, Teresa. La prova testimoniale nel processo penale. $2^{\mathrm{a}}$ ed., Padova: Cedam, 2010.

FEITOZA, Denilson. Direito processual penal: teoria, crítica e práxis, $6^{\mathrm{a}}$ ed., Niterói: Impetus, 2009.

FERNANDES, Antonio Scarance. Tipicidade e sucedâneos de prova. In: FERNANDES, Antonio Scarance; ALMEIDA, José Raul Gavião; MORAES, Maurício Zanoide de (coords). Provas no processo penal - estudo comparado, São Paulo: Saraiva, 2011. 
. Reflexos sobre as noções de eficiência e de garantismo no processo penal. In: Sigilo no Processo Penal: eficiência e garantismo. FERNANDES, Antonio Scarance; ALMEIDA, José Raul Gavião de; MORAES, Maurício Zanoide de (coords). São Paulo: Revista dos Tribunais, 2008.

. Processo Penal Constitucional, $3^{\mathrm{a}}$ ed. revista, atualizada e ampliada, São Paulo: Revista dos tribunais, 2002.

, Processo Penal Constitucional, $6^{\mathrm{a}}$ ed. revista, atualizada e ampliada, São Paulo: Revista dos tribunais, 2010.

- Prova e sucedâneos da prova no processo penal, Revista Brasileira de Ciências Criminais, Revista dos Tribunais, maio-junho de 2007.

. A reação defensiva à imputação, São Paulo: Revista dos Tribunais, 2002.

GOMES FILHO, Antonio Magalhães. Direito à prova no Processo Penal, São Paulo: Revista dos Tribunais, 1997.

. Notas sobre a terminologia da prova (reflexos no processo penal brasileiro). In: YARSHELL, Flávio Luis; MORAES, Maurício Zanoide (Org.). Estudos em homenagem à professora Ada Pellegrini Grinover. 1ª ed., São Paulo: DPJ, 2005.

; BADARÓ, Gustavo Henrique Righi Ivahy. Prova e sucedâneos de prova no processo penal brasileiro. In: Revista Brasileira de Ciências Criminais, $n^{\circ}$ 65, São Paulo: Editora Revista dos Tribunais, março-abril de 2007.

. Provas: Lei 11.690, de 9.6.2008. In: MOURA, Maria Thereza Rocha de Assis. (Org.). As reformas no processo penal: as novas leis de 2008 e os projetos de reforma. São Paulo: Revista dos Tribunais, 2009. 
GOMES, Luiz Flávio. Comentários às Reformas do Código de Processo Penal e da Lei de Trânsito, $1^{\mathrm{a}}$ ed., São Paulo: Revista dos Tribunais, 2008.

GRECO FILHO, Vicente. Tutela constitucional das liberdades. São Paulo: Saraiva, 1989. . Manual de Processo Penal, $8^{\text {a }}$ ed. revista, atualizada e ampliada, São Paulo: Saraiva, 2010.

GRIFANTINI, F.M., Utilizzabilità in dibattimento di atti provenienti dalle fasi anteriori, in: La prova nel dibattimento penale, Torino: Giappichelli, 2007.

GRINOVER. Ada Pellegrini; GOMES FILHO. Antonio Magalhães; FERNANDES. Antonio Scarance. As nulidades no processo penal, $11^{\mathrm{a}}$ ed. revisada, atualizada e ampliada, São Paulo: Revista dos Tribunais, 2009.

. O processo em evolução, Rio de Janeiro: Forense Universitária, 1996.

LARONGA, Antonio. Le prove atipiche nel processo penale, Padova: Cedam, 2002.

LIEBMAN, Enrico Tullio. Manuale di Diritto Processuale Civile, $2^{\mathrm{a}}$ ed., vol. 1, Milano: Giuffrè, 1968.

LOPES JUNIOR. Aury. Sistemas de investigação preliminar no Processo Penal, $1^{\mathrm{a}}$ ed., Rio de Janeiro: Lúmen Júris, 2001.

. Sistemas de investigação preliminar no Processo Penal, $4^{\mathrm{a}}$ ed. revisada atualizada e ampliada, Rio de Janeiro: Lúmen Júris, 2006. 
. A crise do inquérito policial: breve análise dos sistemas de investigação preliminar no processo penal. Revista Ibero-Americana de Ciências Penais, Porto Alegre, ano 1, maio-agosto de 2000, p. 59-60.

.. Direito Processual Penal e sua Conformidade Constitucional, $3^{\mathrm{a}}$ ed. revisada e atualizada, vol. I, Rio de Janeiro: Lumen Juris, 2008.

LOPES, Mariângela Tomé. O reconhecimento como meio de prova - necessidade de reformulação do direito brasileiro. Tese de doutorado defendida na Faculdade de Direito da Universidade de São Paulo em 2011.

MARQUES, José Frederico. Elementos de direito processual penal, $2^{\mathrm{a}}$ ed., vol. 1, Rio de Janeiro: Forense, 1965.

MENDONÇA, Andrey Borges de. Os Elementos Produzidos Durante o Inquérito e as Provas Antecipadas, Cautelares e Irrepetiveis, segundo a Reforma do CPP. In: Reforma Processual Penal, Revista ESMP, Ano 1, Vol. 2, nº 1, julho-dezembro de 2008.

MORAES. Maurício Zanoide de. Presunção de Inocência no processo penal brasileiro: análise da estrutura normativa para a elaboração legislativa e para a decisão judicial. Rio de Janeiro: Lumen Juris, 2010.

NUCCI, Guilherme de Souza. Código de Processo Penal Comentado, 8 a edição revisada, ampliada e atualizada, 2 $2^{\mathrm{a}}$ tiragem, São Paulo: Revista dos Tribunais, 2008.

. Provas no Processo Penal, São Paulo: Revista dos Tribunais, 2009.

PITOMBO, Cleunice A. Valentim Bastos. Da busca e da apreensão no processo penal. Dissertação de mestrado defendida na Faculdade de Direito da Universidade de São Paulo em 1997. 
RANGEL, Paulo. Direito Processual Penal. 14ª ed., Rio de Janeiro: Lumen Juris, 2008.

SAAD, Marta. O direito de defesa no inquérito policial - Coleção Estudos de processo Penal Joaquim Canuto Mendes de Almeida, vol. 9, São Paulo: Revista dos Tribunais, 2004.

SALLES JUNIOR, Romeu de Almeida. Inquérito policial e ação penal: indagações, doutrina, jurisprudência, prática. $6^{\text {a }}$ ed. revisada, ampliada e atualizada, São Paulo: Saraiva, 1992.

SIRACUSANO, Delfino. Le prove: $i$ mezzi di ricerca della prova. In: SIRACUSANO, Delfino; GALATI, Antonini; TRANCHINA, Giovanni; ZAPPALÀ, Enzo. Diritto Processuale Penale, vol. 1, Milano: Giuffrè, 2006.

TONINI, Paolo. A prova no processo penal italiano (tradução de Alexandra Martins e Daniele Mróz). São Paulo: Revista dos tribunais, 2002.

TOURINHO FILHO, Fernando da Costa. Manual de Processo Penal. São Paulo: Saraiva, $8^{\mathrm{a}}$ ed. revisada e atualizada, 2006.

. Manual de Processo Penal. São Paulo: Saraiva, 12 ed. revisada e atualizada, 2009.

. Código de Processo Penal Comentado (artigos $1^{o}$ ao 393), $13^{\mathrm{a}}$ ed. revisada e atualizada, São Paulo, Saraiva, 2010.

TRAMONTANO, Luigi. Codice di procedura penale spiegato, $9^{\mathrm{a}}$ ed., Piacenza: La tribuna, 2011.

UBERTIS, Giulio. Il contraddittorio nella formazione della prova penale. In: YARSHELL, Flávio Luis; MORAES, Maurício Zanoide (Org.). Estudos em homenagem à professora Ada Pellegrini Grinover. 1ª ed., São Paulo: DPJ, 2005. 
ZILLI, Marcos. O pomar e as pragas. In: Boletim do IBCCRIM, ano 16, n. 188, julho 2008. 